

\title{
Design, arte e consumo
}

\author{
Alécio Rossi Filho
}

\begin{tabular}{|c|c|c|}
\hline \multicolumn{3}{|c|}{ Errata } \\
\hline \multicolumn{3}{|c|}{$\begin{array}{l}\text { Rossi Filho, Alécio. Design, arte e consumo. São Paulo, } 2018 . \text {. } \\
\text { Tese (Doutorado) - Faculdade de Arquitetura e Urbanismo da } \\
\text { Universidade de São Paulo. Área de concentração: Design e } \\
\text { Arquitetura. }\end{array}$} \\
\hline Folha & Linha & Acrescentar \\
\hline 05 & 03 & Design, art and consumption \\
\hline 12 & 16 & Palavras chave/Keywords \\
\hline 13 & 16 & design / arte / consumo \\
\hline 13 & 30 & design/art / consumption \\
\hline
\end{tabular}

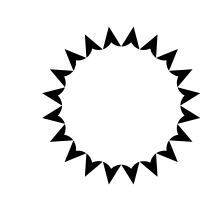

Programa de pós-graduação FAUUSP Doutorado Área de concentração Design e Arquitetura Linha de pesquisa Projeto, Processos e Linguagens em Design Orientador Prof. Dr. Vicente Gil Filho 
"Design não é uma armadilha."

Vicente Gil

Catalogação na Publicação

Faculdade de Arquitetura e Urbanismo da Universidade de São Paulo

Rossi Filho, Alecio

Design, arte e consumo / Alecio Rossi Filho; orientador 204. Gil Filho, São Paulo, 2018. Tese (Doutorado) - Faculdade de Arquitetura e Urbanismo
da Universidade de São Paulo. Área de concentração: Design e Arquitetura.

1. Design. 2. Arte. 3. Consumo. I. Gil Filho, Vic orient. IT. Título. A

Elaborada eletronicamente através do formulário disponivel em: ‘http://www.fau.usp.brffichacatalografical/ 
Agradeço ao meu orientador e amigo

(n) marcante e olhar perspicaz.

Agradeço a Profa. Dra. Elaine Caramella pela interlocução inteligente e atenta,

Agradeço a Profa. Dra. Marlyvan Moraes de Alencar pelas trocas e pelo apoio.

Ofereço este trabalho à minha mãe Dirce Zocal Rossi por acreditar que o
conhecimento nos transforma e por sempre acreditar em mim. 
Resumo / Abstract

012

Narrativas relacionais

014

Marca mercadoria

O consumo abstrato

017

Arte

Design difuso

029

Desejo

Os corpos misturados

039

\section{Design e permanência}

Natural $x$ artificial

047

\section{Economia: decrescimento}

Aceleração e equilíbrio dinâmico

Objetos

Utilitários e inutilitários

057

Espaços

Ambientes e fronteiras

061

Design e caos

Métodos projetuais complexos

Arte e Design

Intenção e projeto

085

Design mercadoria

Marca, consumo e luxo

099

\section{Curadoria}

Design e outras produções culturais

Gucci

Estratégias de reposicionamento

123

\section{Sem gênero}

Ideologia de gênero e consumo

129

Millennial

Música e posicionamento político

133

Pixo de luxo

Transgressão autorizado

143

\section{Campanhas nonsense}

Histórias reais inventadas

149

Reforma on-line

O consumo digital de objetos

159

Alexander McQueen

Belos imperfeitos

163

Low tech hight tech

Artesania, arte e design

173

Design e arte

Estratégias de persuasão

187

\section{Referências}

197

Cólofon 
Esta tese busca refletir sobre limites, fronteiras e sobreposições entre design, arte, moda, comunicação, comportamento e consumo. A partir da seleção de imagens e textos disponibilizados em diferentes suportes livros, objetos, audiovisuais, plataformas digitais, vitrines - analisou-se estratégias de marcas de vestuário em que a interrelação entre artistas, designers e outros agentes de produção cultural contribui para a construção de ima-gem pública para marcas, atribuindo a elas valor. Obras e objetos fundemse num processo de sobreposição, que resulta no desenvolvimento de sentido comum. Desta forma, marcas atuantes em mercado global utilizam-se da fusão arte/design para fortalecer, na percepção do consumidor, qualidade e valor de produtos e serviços.

\section{Resumo / Abstract Palavras chave / Keywords}

design/ arte/ consumo

This thesis seeks to reflect on limits, borders and overlaps between design, art, fashion, communication, behavior and consumption. From the selection of images and texts made available in different media - books, objects, audiovisuals, digital platforms, shop windows - strategies were analyzed of clothing brandsin which the interrelation between artists, designers and other cultural production agents contribute to the construction of public image for brands, assigning them value. Works and objects merge into an overlapping process, which results in the development of common sense. In this way, brands active in the global market use the fusion art/design to strengthen, in consumer percep-tion, quality and value of products and services.

design/ art/ consumption 
Esta tese busca refletir sobre limites, fronteiras e sobreposições entre design, arte, moda, comunicação, comportamento e consumo. A partir da seleção de imagens e textos disponibilizados em diferentes suportes - livros, objetos, audiovisuais, plataformas digitais, vitrines analisou-se estratégias de marcas de vestuário em que a interrelação entre artistas, designers e outros agentes de produção cultural contribui para a construção de imagem pública para marcas, atribuindo a elas valor. Desta forma, marcas atuantes em mercado global utilizam-se da fusão arte/design para fortalecer, na percepção do consumidor, qualidade e valor de produtos e serviços.

A construção da tese apoiou-se em uma combinação entre as linguagens verbal e visual: imagens/legendas e escrita podem ser lidos e interpretados de forma independente, o que permite três modos de aproximação: um a ser desenhado de modo tradicional, associando texto e imagem, como se o primeiro fosse o fundamento e a segunda a ilustração, supremacia dada ao texto. Outro que se volta para o discurso visual, entendendo a força das imagens e se colocando em busca de seus significados: o que elas querem dizer; o que provocam e como provocam? Finalmente, o terceiro modo que é aquele que busca que texto e imagem se estruturem de modo simétrico, ambos com a mesma importância, como partes de um processo e de uma pesquisa que se coloca como uma composição, como um ato relacional, no qual a melhor leitura é aquela que põe texto e imagem como partes indissociáveis do estudo. Assim, as abordagens e narrativas acontecem simultaneamente, cabendo ao leitor o desenvolvimento do contexto e as possibilidades de interpretação a partir de dados e pensamentos aqui registrados. Imagens e textos podem funcionar como multitelas ou plataformas tendo, cada uma delas, sentido próprio, mas ganhando complexidade ao serem combinadas. 


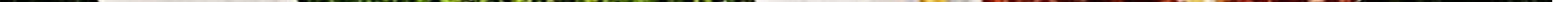

\section{Marca mercadoria}

O consumo abstrato

As marcas apoiam-se em imagens interrelacionadas em forma de complexa rede de signos e, assim, constroem seu valor. Entender estratégias de marcas contemporâneas que se configuram como código, buscar decodificar e decifrar este código foram os objetivos da dissertação de mestrado desenvolvido em 2005 na UNESP, campus de Bauru, São Paulo.

Ao iniciar o doutorado havia uma preocupação em entender os mecanismos utilizados por grandes corporações para construir uma imagem de produtos ou serviços junto a seu público consumidor, que fosse suficientemente forte Imagem e consumo para que esta imagem prevalecesse dominante frente a Sobreposição de cartazes no Alógica da sobreposição e
putras imagens de produtos e serviços concorentes do efêmero aparece nos espaços similares. O caráter simbólico das marcas, as analogias, acelerado de consumo e descarte. as associações e uma série de outras estratégias utilizadas $\begin{array}{ll}\text { Paris, } 2016 \\ \text { Fotodo outor }\end{array}$ 
para construir significados desejados por estas corporações instigavam-me a refletir sobre o que as marcas significam e ainda, mais do que isto, a saber como elas chegam a significar o que significam.

$\mathrm{O}$ que a marca comunica? O que a marca representa? O que é a imagem da marca? Neste sentido, valor é igual a imagem, pois é esta que lhe dá significado?

A marca, entendida como signo, associa-se, ora por similaridade, ora por contigüidade a uma complexidade de estratégias de captura perceptiva do consumidor, de caráter eminentemente persuasivo que, ressignificando concepções permanentemente e de maneira inusitada dão valor ao produto.

Grandes marcas, em especial ligadas ao mercado da moda, têm desenvolvido estratégias de aproximar design e arte. O objetivo dessa aproximação parece ser a de quebrar as fronteiras entre arte e design buscando atribuir aos objetos produzidos a percepção de que são objetos especiais com atributos comuns à arte. Com essa estratégia e com instrumentos de comunicação também alinhados, as marcas constroem valor para os seus produtos além do que poderia valer sua materialidade.

Busco analisar, compreender e sistematizar estratégias, mecanismos e procedimentos que conectam arte e design no desenvolvimento de produtos e serviços pertencentes a grandes marcas com distribuição em mercados globais e apontar conexões conceituais entre as áreas de Arte, Design e Comunicação.

Refletir sobre as estruturas de construcão de códigos de comunicação para atribuir significados e valor para produtos e serviços criados e produzidos para mercados e distribuição global.

Grandes corporações, com atuação em diferentes países, utilizam-se de aproximações entre artes visuais e design com o objetivo de alterar a percepção do público relativa
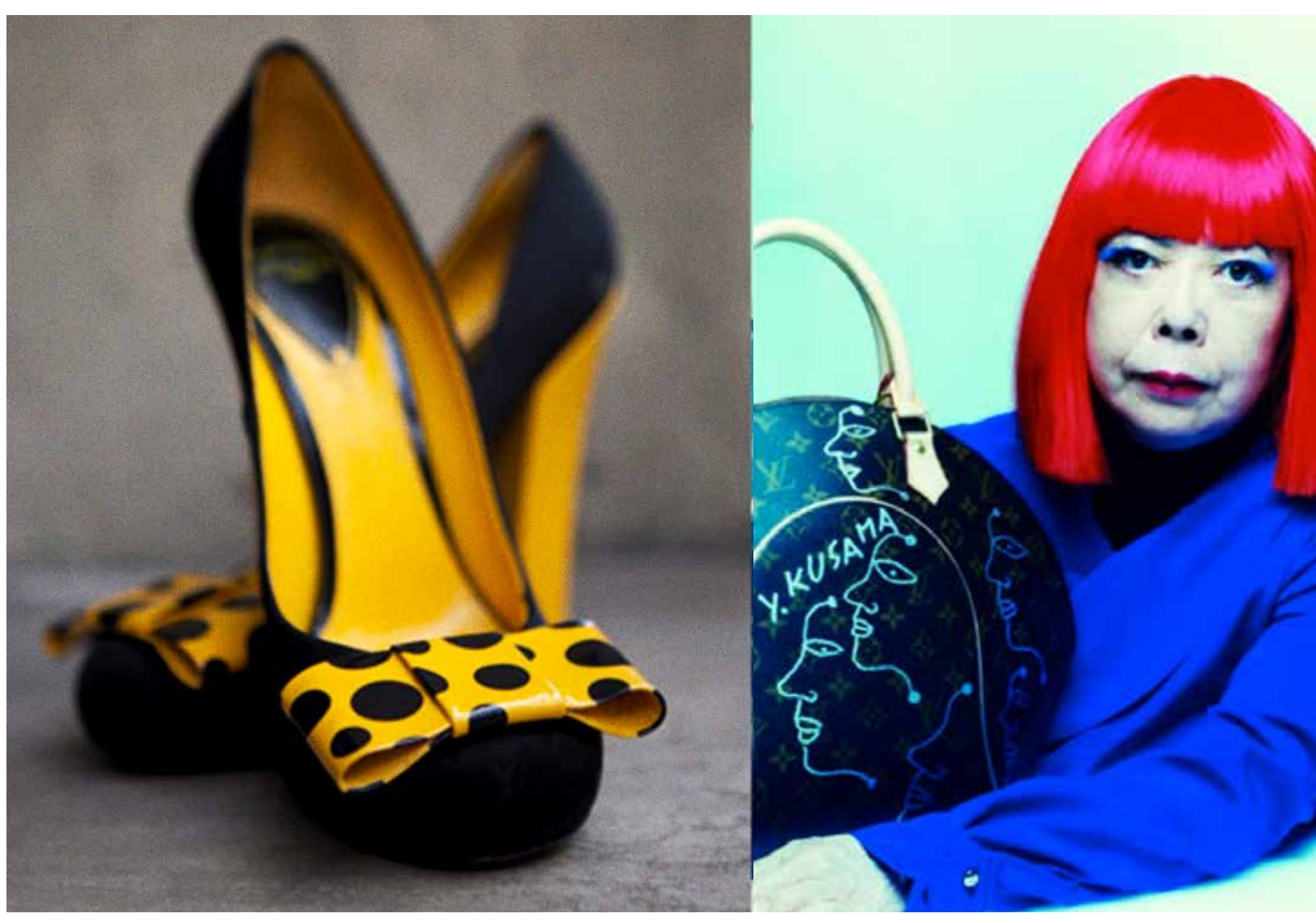

ao consumo e a atribuição de valor.

Yayoi Kusama

As estratégias utilizadas para mudar a percepção do público referente a serviços e produtos apoiam-se no design, no marketing, na arte e na publicidade. Discutir essas estratégias e sistematizá-las estruturam a hipótese desse projeto.

Analisar estratégias de marca e suas relações com a afetividade do público, em especial as relações fortalecidas pela aproximação de marcas por meio de sua produção cultural. Em síntese, como as marcas estimulam e desenvolvem relações afetivas entre consumidor e produto.

A relação entre o conhecer e o reconhecer faz do tempo e da memória do consumidor instrumento de valor. Memória é o conjunto de experiências vividas e conservadas. Memória é tudo aquilo que fez sentido algum dia. Memória não é um arquivo com imagens prontas e 


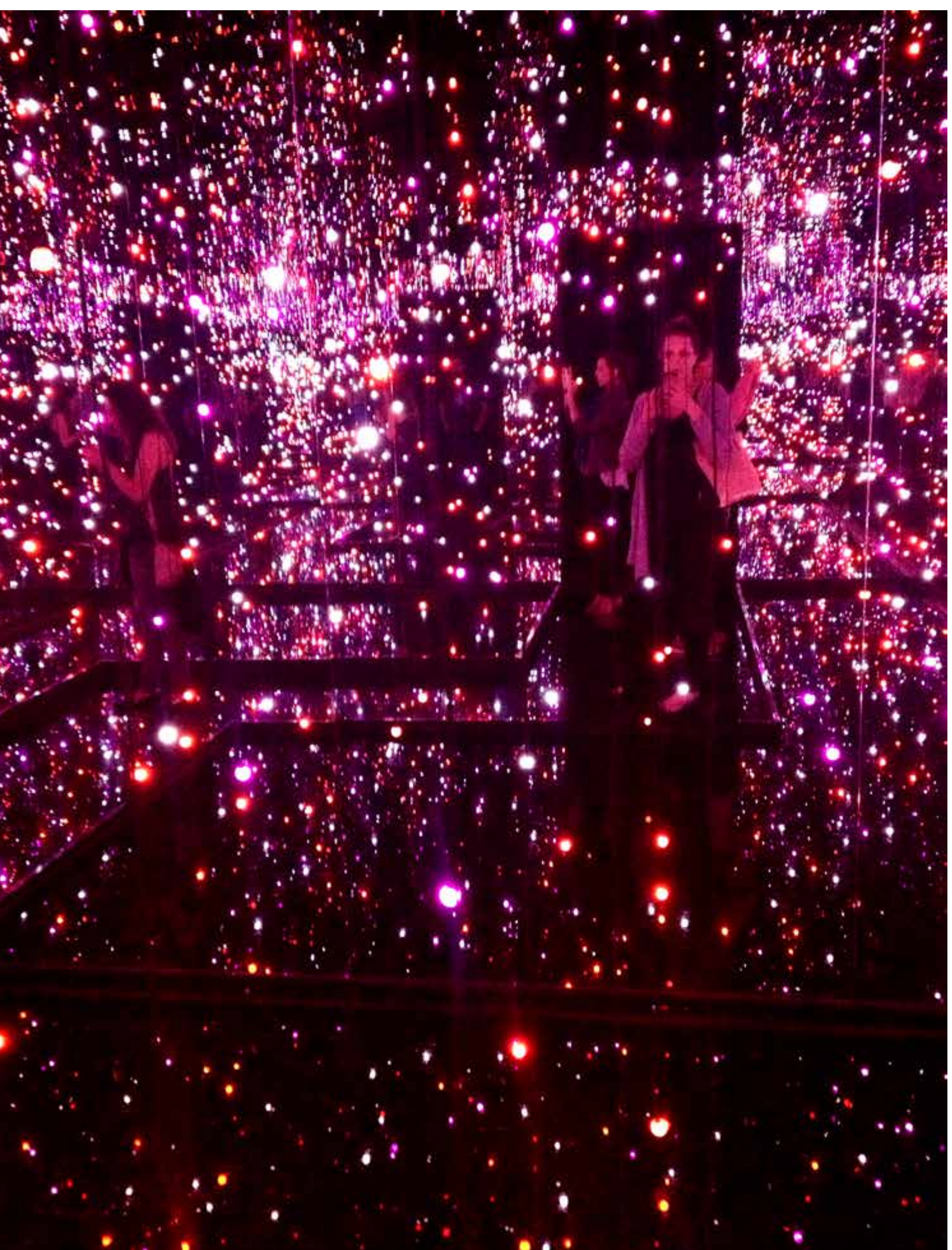

organizadas como em um banco de dados, mas um conjunto de informações significativas das quais se lança mão, de forma a combinar estas informações, transformando-as em imagens mentais, construções momentâneas (DAMASIO, 1996).

É possível se desenvolver uma memória afetiva com os produtos com os quais se aprende a conviver. As estratégias de marketing e a publicidade cravam a marca como imagem mental num processo de automatização perceptiva. Pela fidelidade de consumo é possível reiterar identidades quando repetidamente são manifestas as opções e preferências de compra. Conhecer e reconhecer contribuem para a fixação da marca.

As estratégias de marketing funcionam bem na construção de uma nova marca quando se detecta a recorrência de consumo de um produto. Por sua vez, a moeda de troca diz respeito a relação de valor da marca que compõe o conjunto de ações que têm por objetivo fortalecer sua imagem junto ao público consumidor.

Desta forma, o uso de imagens de celebridades, atletas e personalidades públicas em campanhas de publicidade agrega valor a marcas, produtos e serviços. Assim funcionam os rankings do Top of mind, quando fazem suas pesquisas junto ao consumidor. Este, espontaneamente, aponta as marcas que ele tem na memória acerca dos produtos de limpeza, refrigerantes, eletrodomésticos, etc. Dessa memória de marcas, elaboram uma lista que é amplamente divulgada. As mais lembradas são as de maior valor. A partir desta prática, a marca também é produto da memória.

Como parte do material de pesquisa está o Projeto da Louis Vuitton que se utilizou da estratégia de licenciamento de produtos ancorados na obra da artista japonesa YaYoi Kusama, em 2012.

Resultado do centro de pesquisas de comportamento e . 


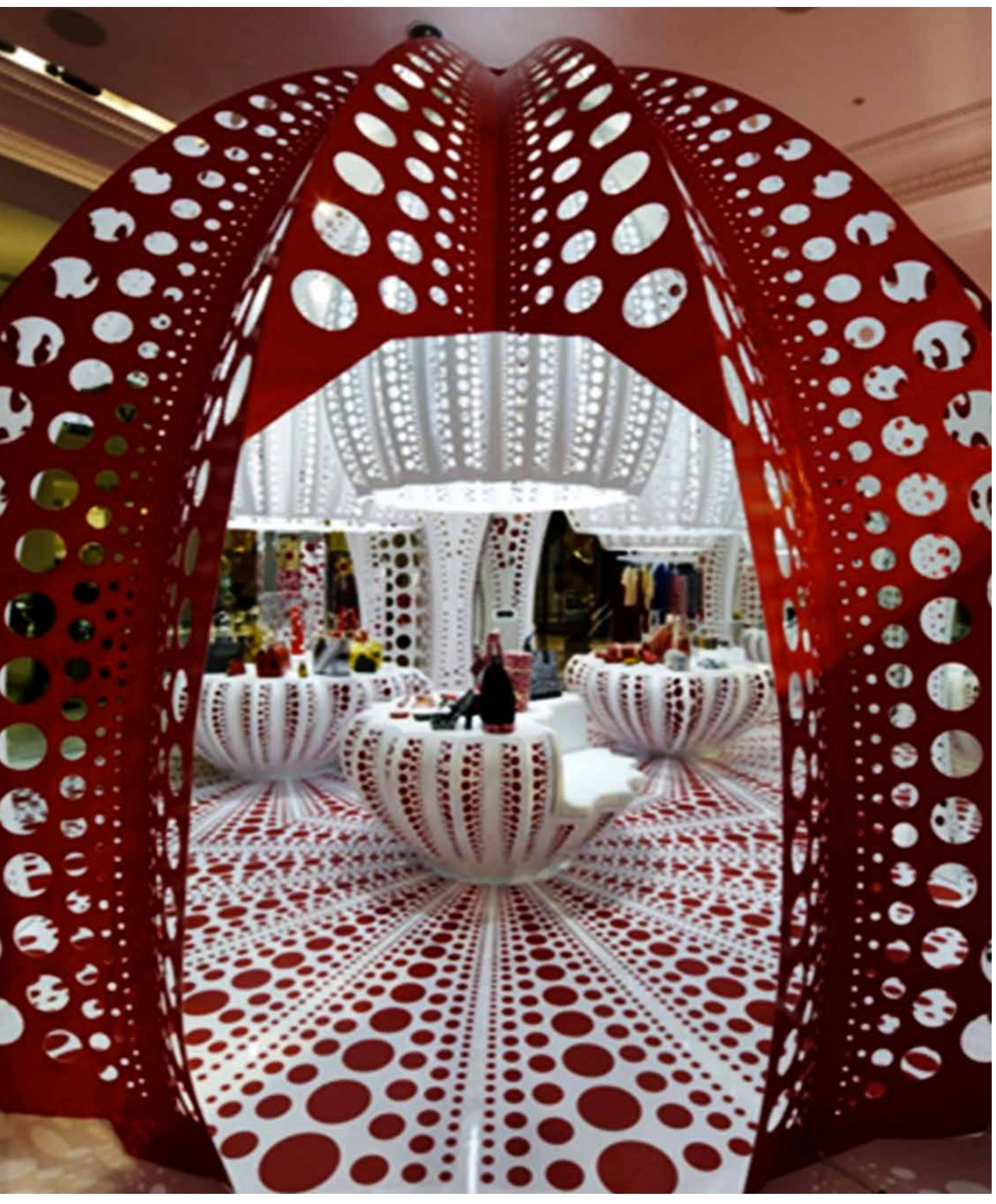

Ponto de venda

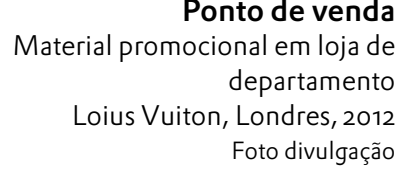

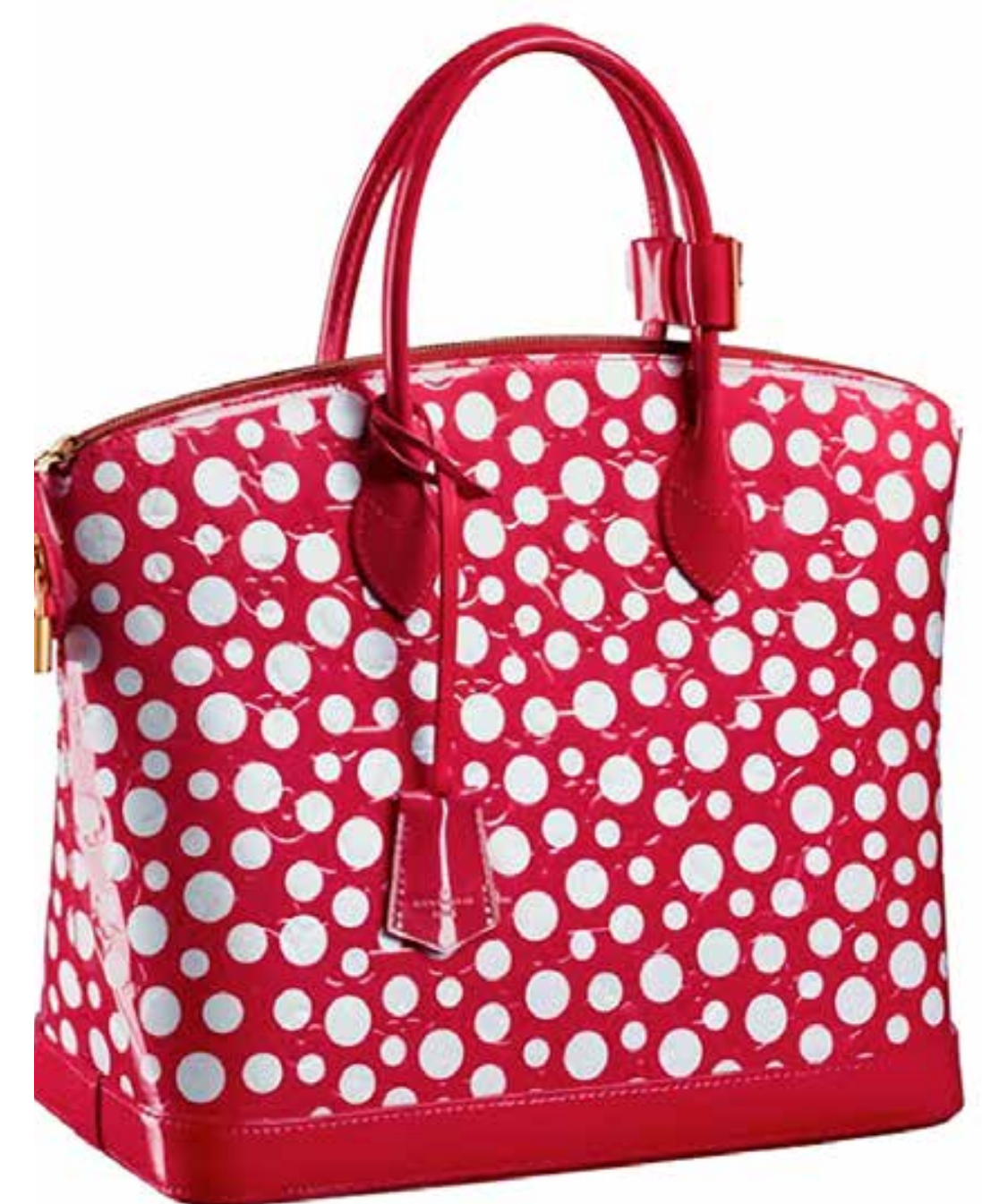

O design e a arte articulam-se como elementos importan- Bolsa Infinity Kusama

tes que configuram atividades específicas de comunicação e publicidade em estratégias que misturam discurso, Londres, 2012
Imagem na objetos e acontecimentos. E ainda, o design e a arte são utilizados nestas estratégias de persuasão, contribuindo com a percepção de valor de produtos e serviços. 


\section{Arte \\ Design difuso}

Design e arte. Toma-se como ponto de partida para reflexão pequenos trechos de autores que se posicionam diante de conceitos tradicionais de cada uma dessas áreas de conhecimento.

Para Flusser (2007), o design direciona à criação de um mundo artificial, desta forma, todos os artefatos com os quais se convive afastam o homem do que seria o mundo natural. Como um contraponto, a definição de arte para Bourriaud, a coloca em relação com o mundo.

Não se pretende dedicar à delimitação de territórios, limites ou fronteiras entre estas áreas de conhecimento, mas refletir sobre as intersecções, sobreposições e sobre a fluidez destes conceitos. Para a cultura contemporane o que representa exatamente essa mistura? O que se opõe aos conceitos estabelecidos de arte e design?

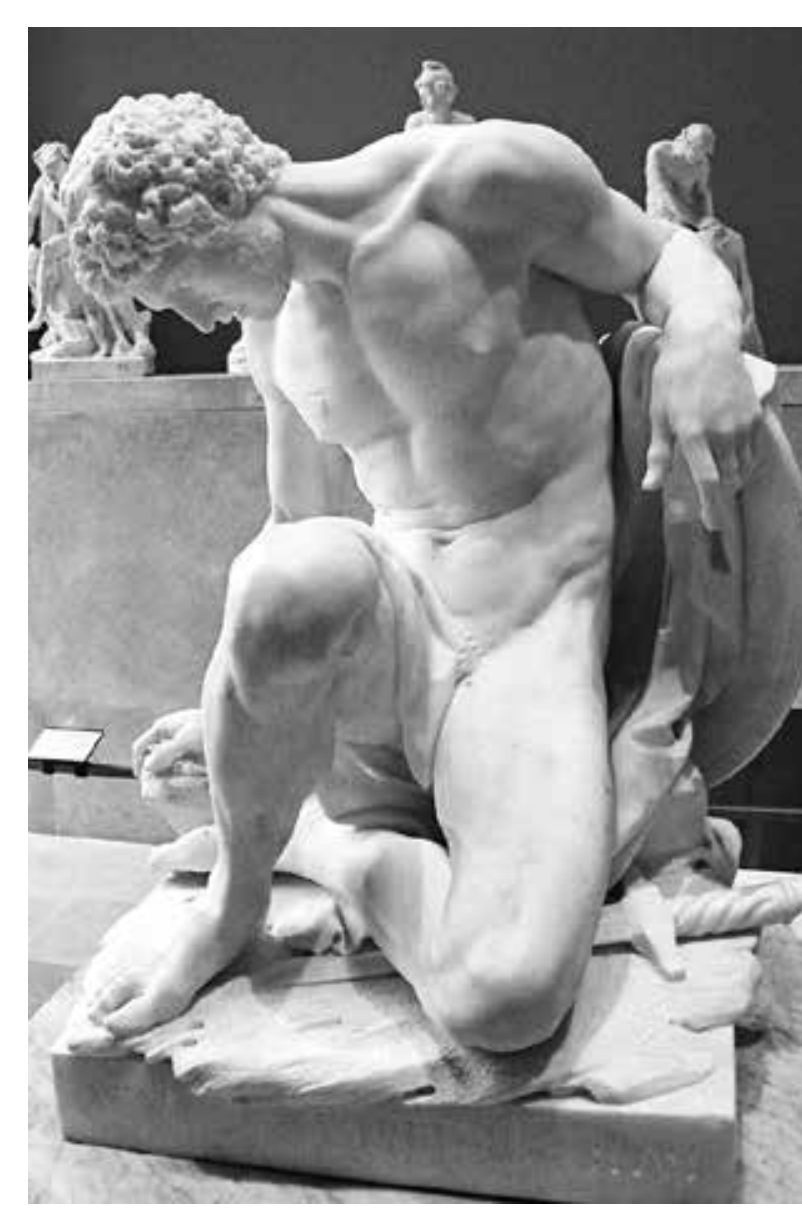

"A arte é uma atividade que consiste na produção de relações com o mundo com a ajuda de sinais, formas, gestos ou objetos." BOURRIAUD, 2009, p.147 Os artistas buscam a tecnologia contemporânea para representar 0 corpo humano e a natureza.

Acima Valérie Montalbetti

Dying gladiator, 1776

\section{À esquerda}

Aluminium Girl, 2003

New Museum

Curadoria de Jeff Koons 

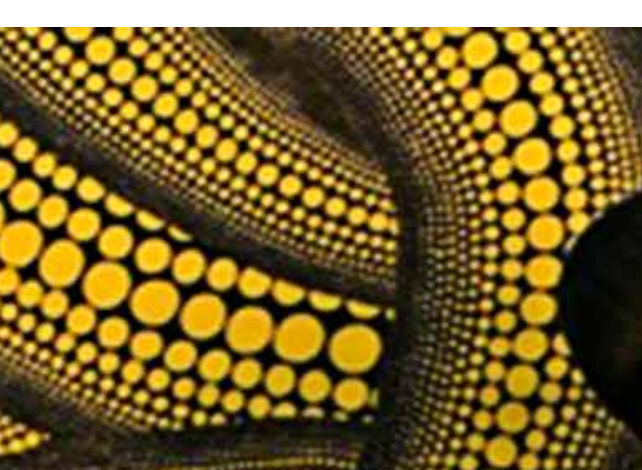

Hown
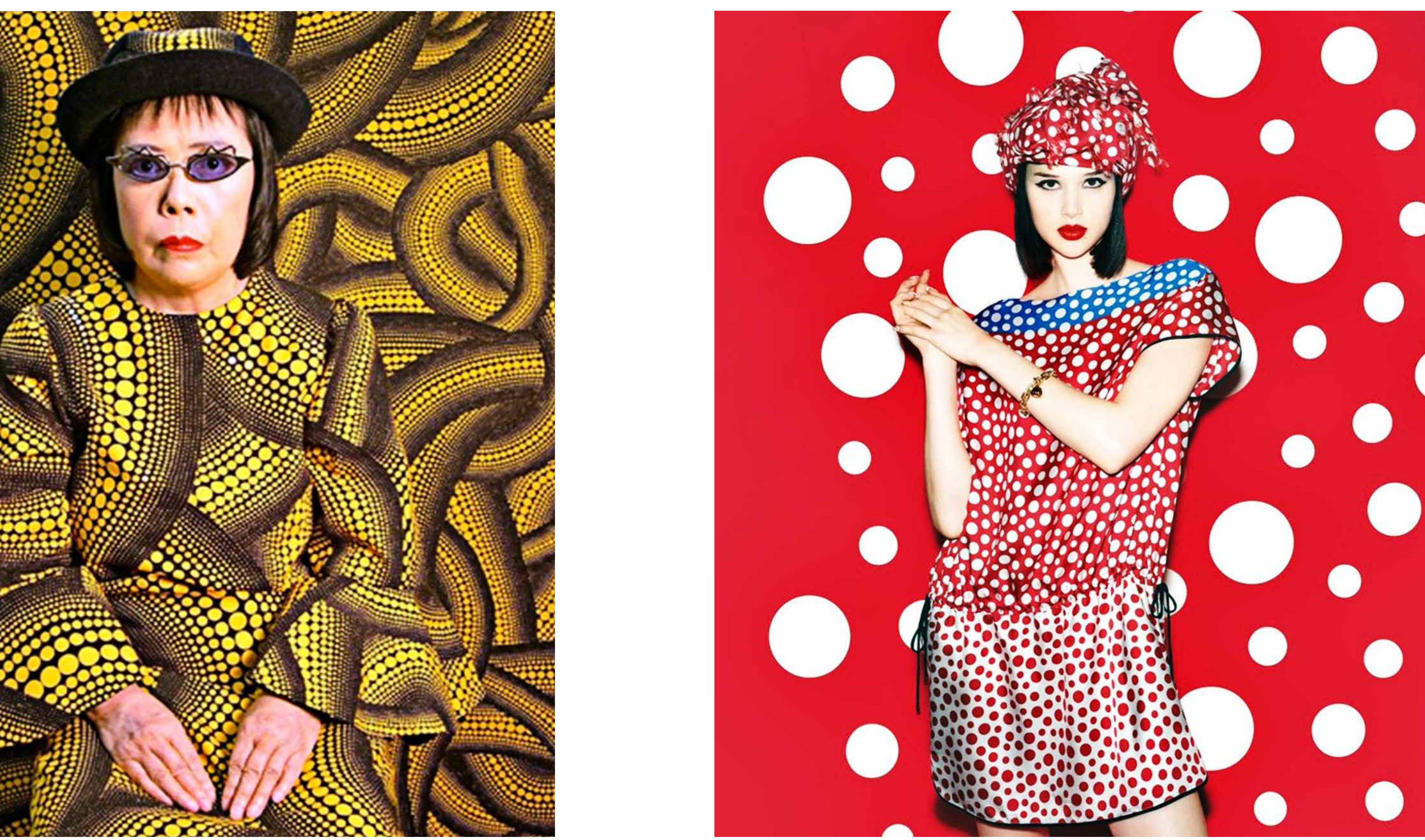

$$
\begin{array}{r}
\text { Yayoi Kusama } \\
\text { Campanha de lançamento } \\
\text { Louis Vuitton } \\
\text { Londres, } 2012 \\
\text { Foto de divulgação }
\end{array}
$$

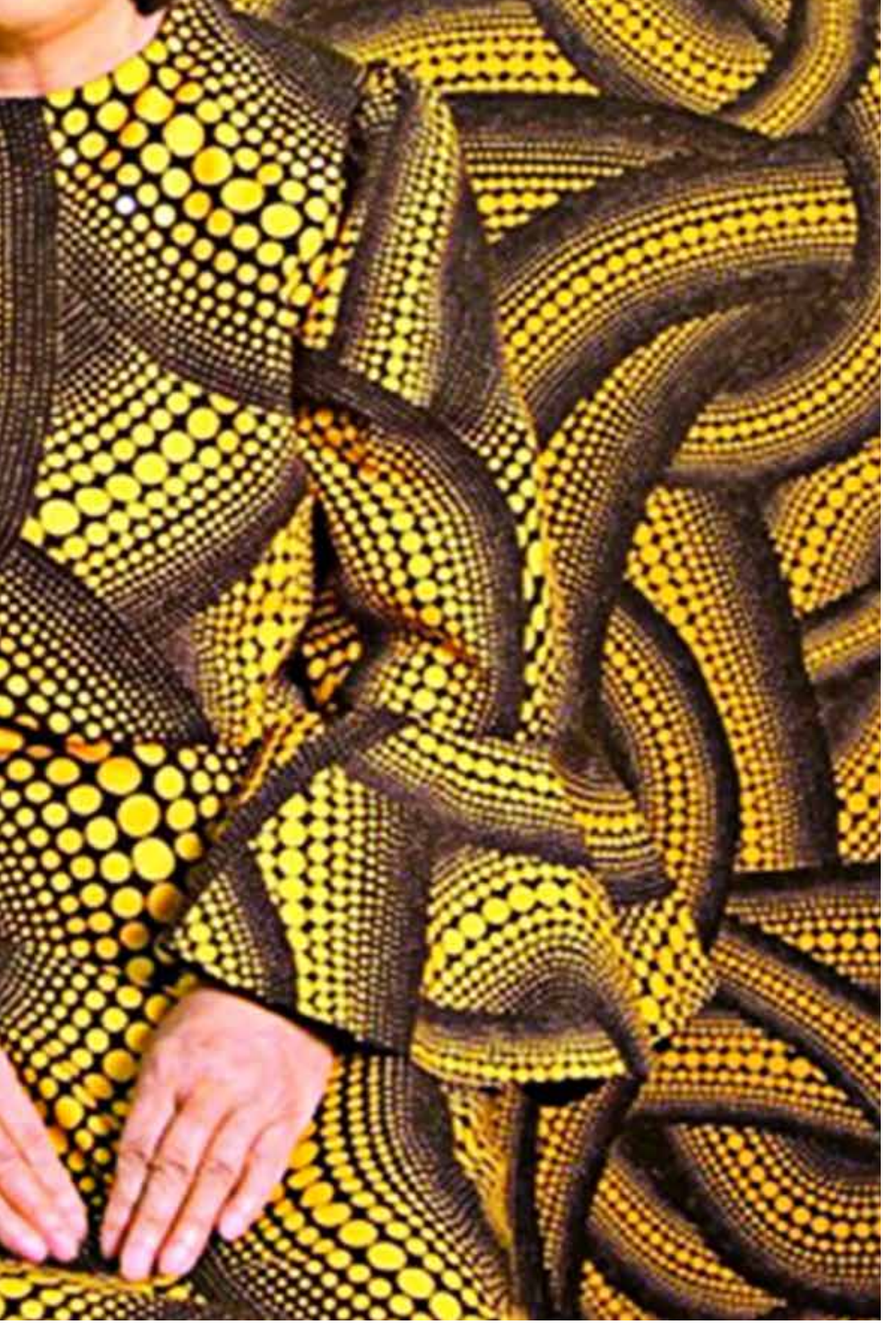

soxinita
Infinity Kusama Londres, 2012
Foto de divulgaçăo Campanha de lançamento 


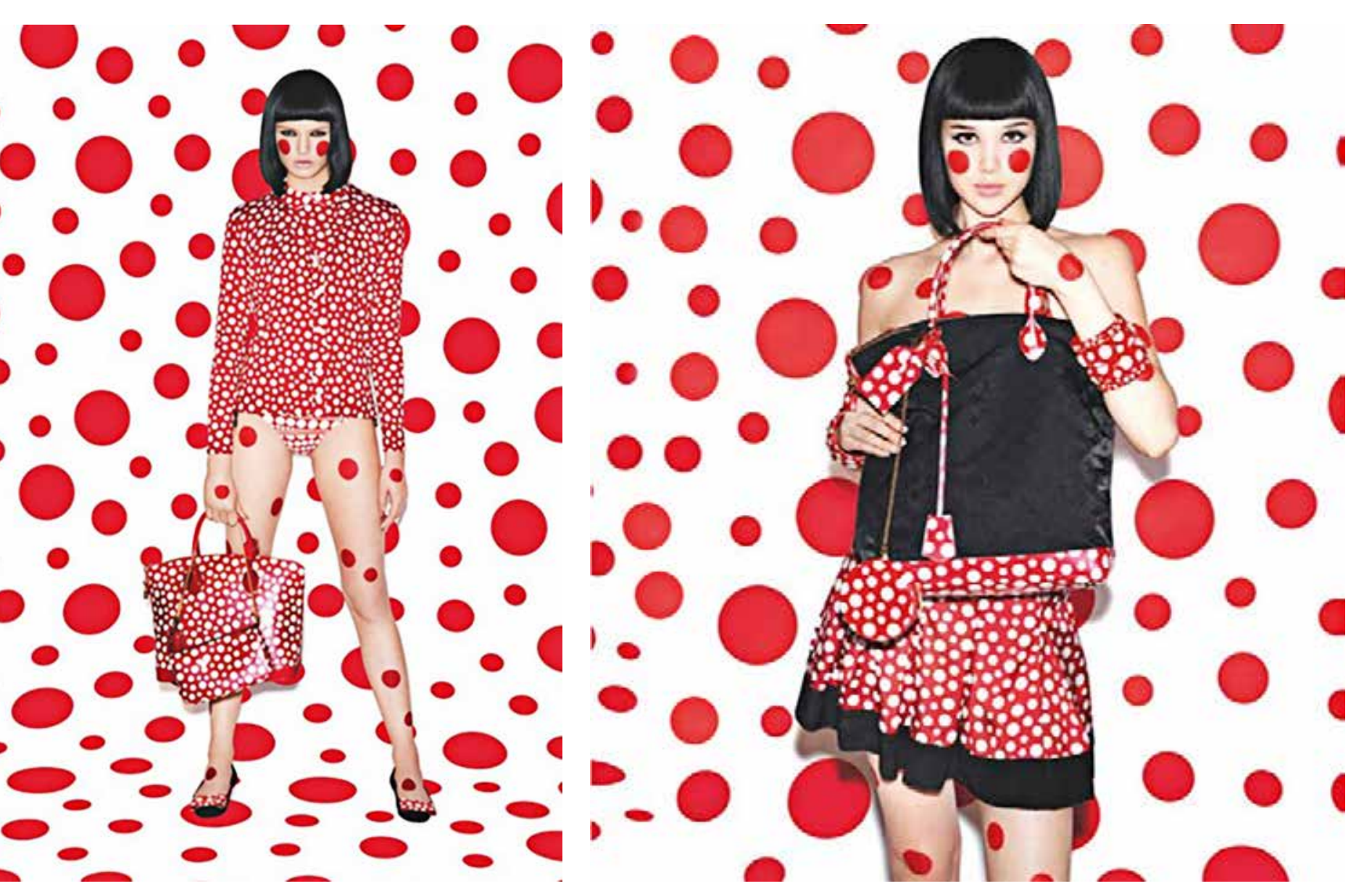

Infinity Kusama Pretende-se discutir a atuação do designer e do design Campanhade lançamento como campo difuso, adaptável a realidades flexíveis e

Fotos de divulgação áveis de uso e que coloca em xeque as funções pré-estabelecidas dos objetos e do pensamento contemporâneo assim como as relações de produção e consumo de objetos, serviços e pensamentos.

Vale também resgatar ou desdobrar o que se tomará como contemporâneo. Apoia-se em Agamben (2009), em sua abordagem do tempo de produção do pensamento e o tempo de produção cultural, tal como analisar os acontecimentos simultaneamente e posicionar-se diante deles, quando cita Roland Barthes para afirmar que "O contemporâneo é o intempestivo" (p.58)

O contemporâneo, para Agamben, é posicionar- se diante dos acontecimentos culturais de seu tempo de forma ativa, assumindo um distanciamento que ao contrário da

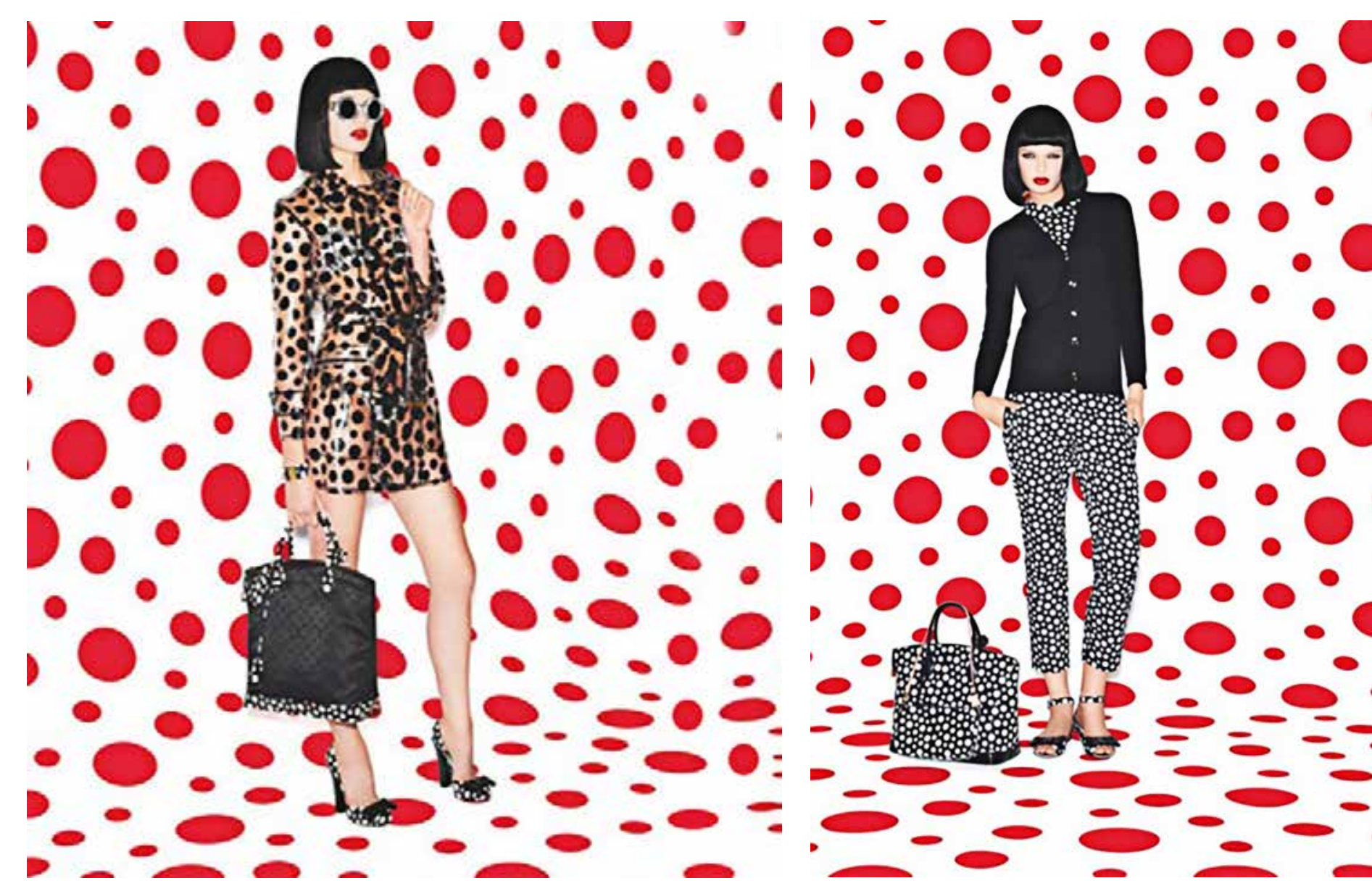

simples constatação se coloque como um posionamento tensionado e crítico.

O tempo da moda esté experiência. A moda se equilibra entre a atrasado, tem sempre o atualidade e a inatualidade, entre o que inrrompe e o que forma de um limiar inaprese afirma por um tempo e o que se torna obsoleto quase ensível, entre um 'ainda não' no momento em que se espalha. A afirmação da moda e um 'não mais' está em sua negacão, em sua ultrapassagem.

AGAMBEN, 2009, p.67

E assim, é nesse tempo do que se mantem e o do que escapa, do que clareia a ponto de não se deixar ver que se dá a experiência do contemporâneo, como o que é não sendo mais.

A escolha destes autores como ponto de partida se dá, não por concordar plenamente com cada um deles, mas exatamente pelo desejo de construir uma reflexão sobre as suas divergências e pontos de conexão. 


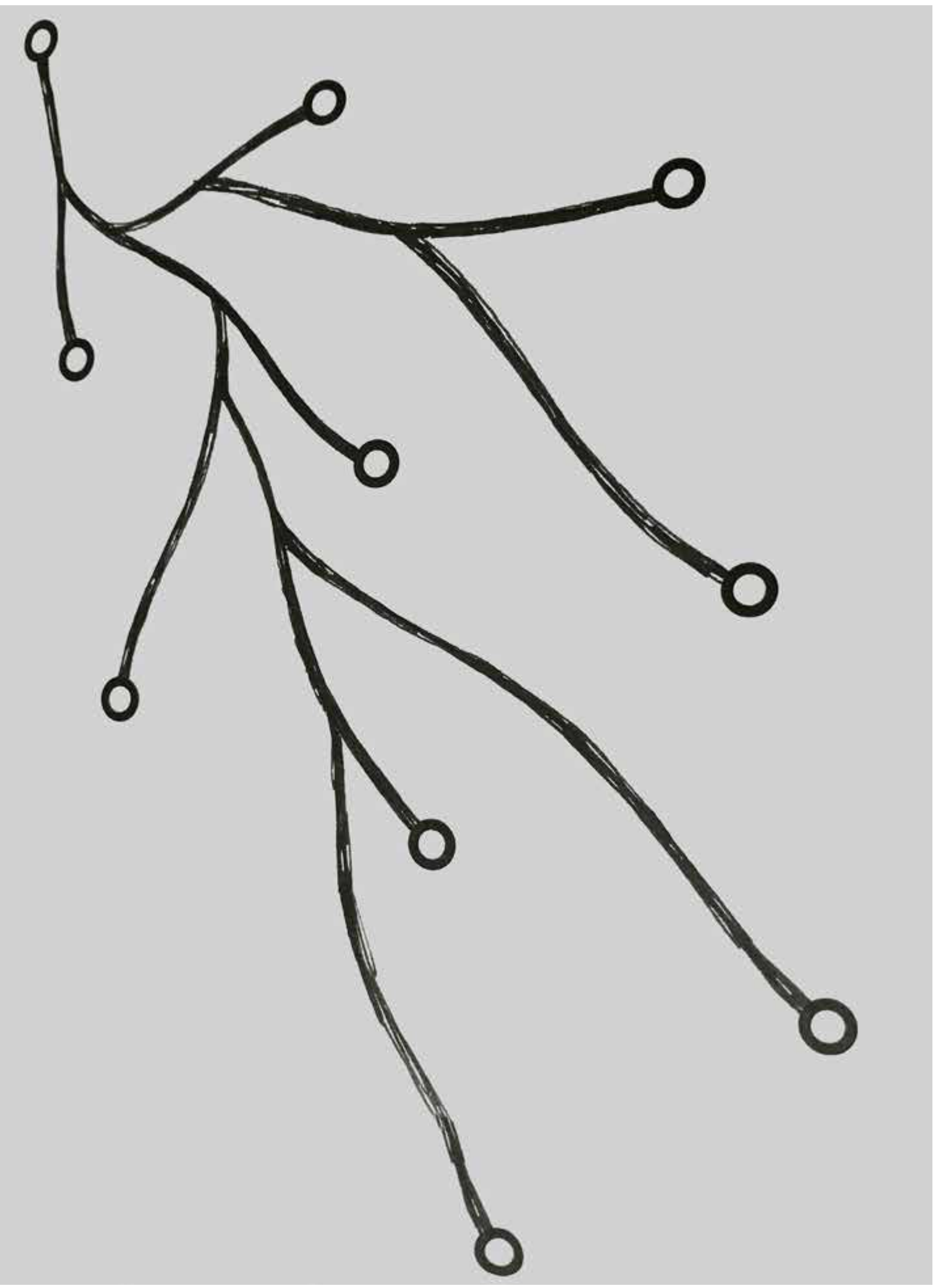

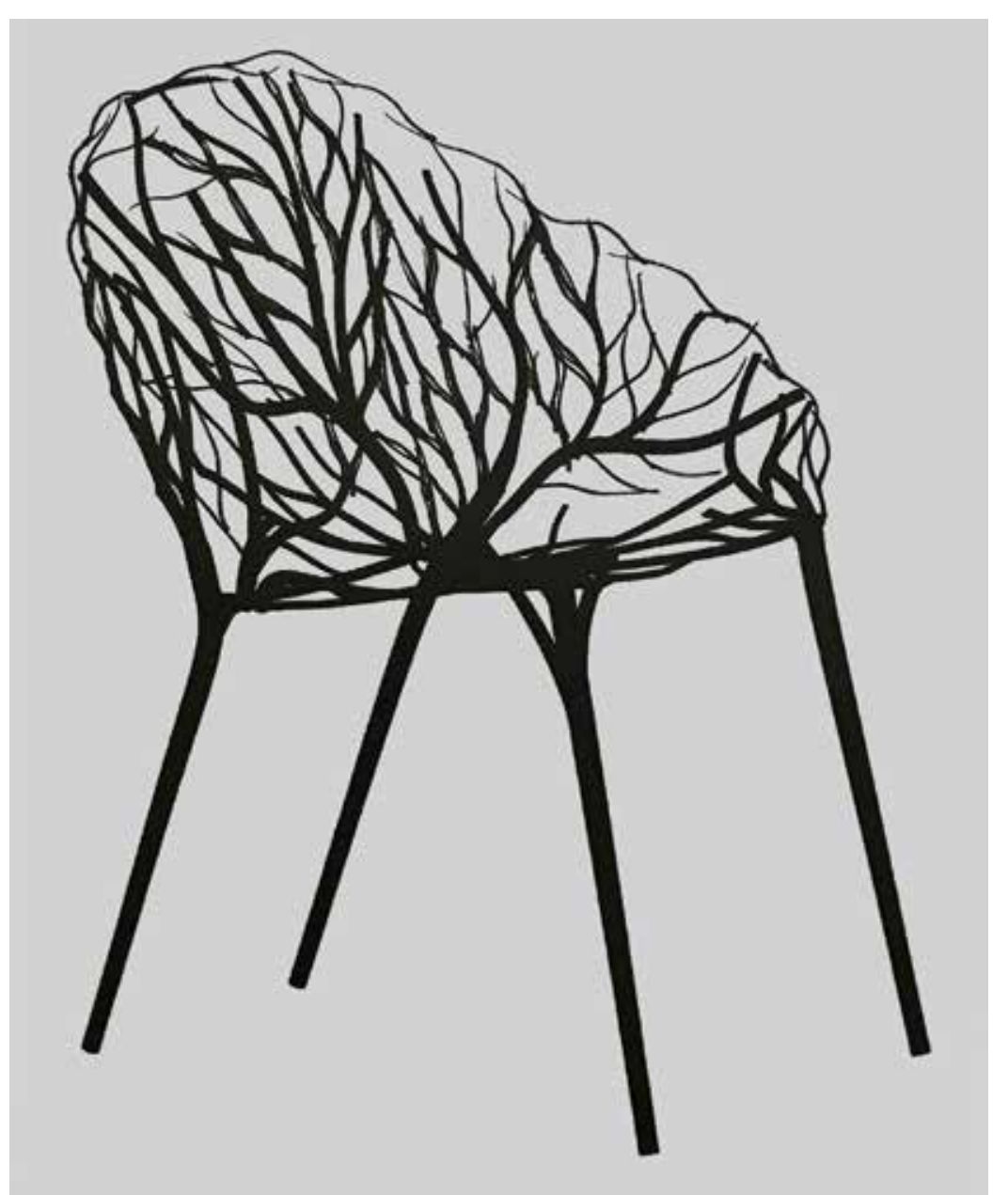

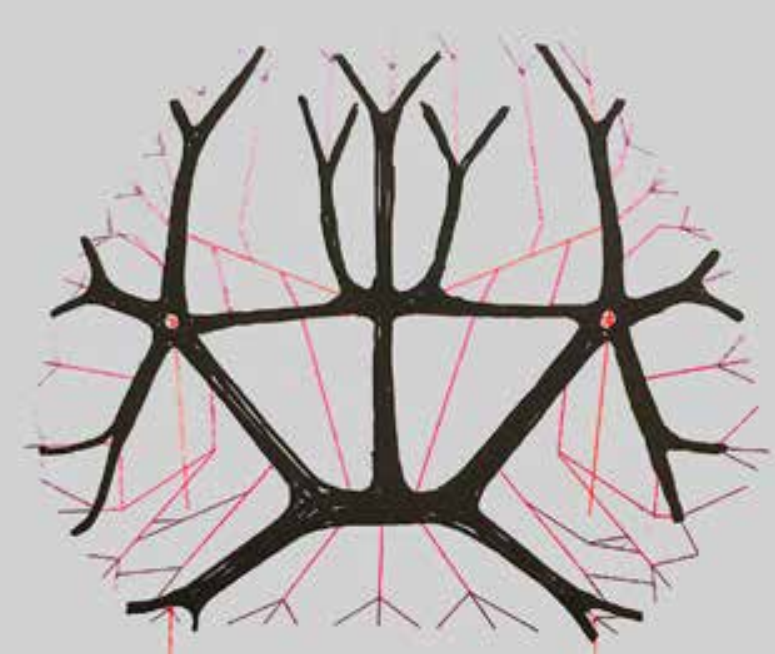

pelo que se é, mas pelo que se poderia ser ao possuir objetos desejáveis. As pessoas são avaliadas pelo que parecem ser e pelo que possuem, assim a posse e sua exibição constroem identidade e imagem pessoais. Tornar visivel a posse transforma o consumidor em modelo a ser imitado. A posse determina o sucesso e por isso desenha um ciclo quase infindável.
Ronan \& Erwan Bouroullec. Estudos e rascunhos evidenciam processo A criação dos designers franceses. constante pesquisa em tecnologias de dupla de irmãos se destaque com objetos presentes nos mais importantes museus 




Desejo

O desejo de posse e o desenho do eu futuro (possuidor de objetos e artefatos) será sempre um projeto em execução. Ele evoca uma sensação de urgência pois os objetos de desejo estão quase sempre representados por imagens, o alcance dos olhos. Consome-se, assim, a imagem dos ostálgico. A ideia do vintage, mento como momento único e irrecuperável. Fortalece uma exclusividade questionável. 

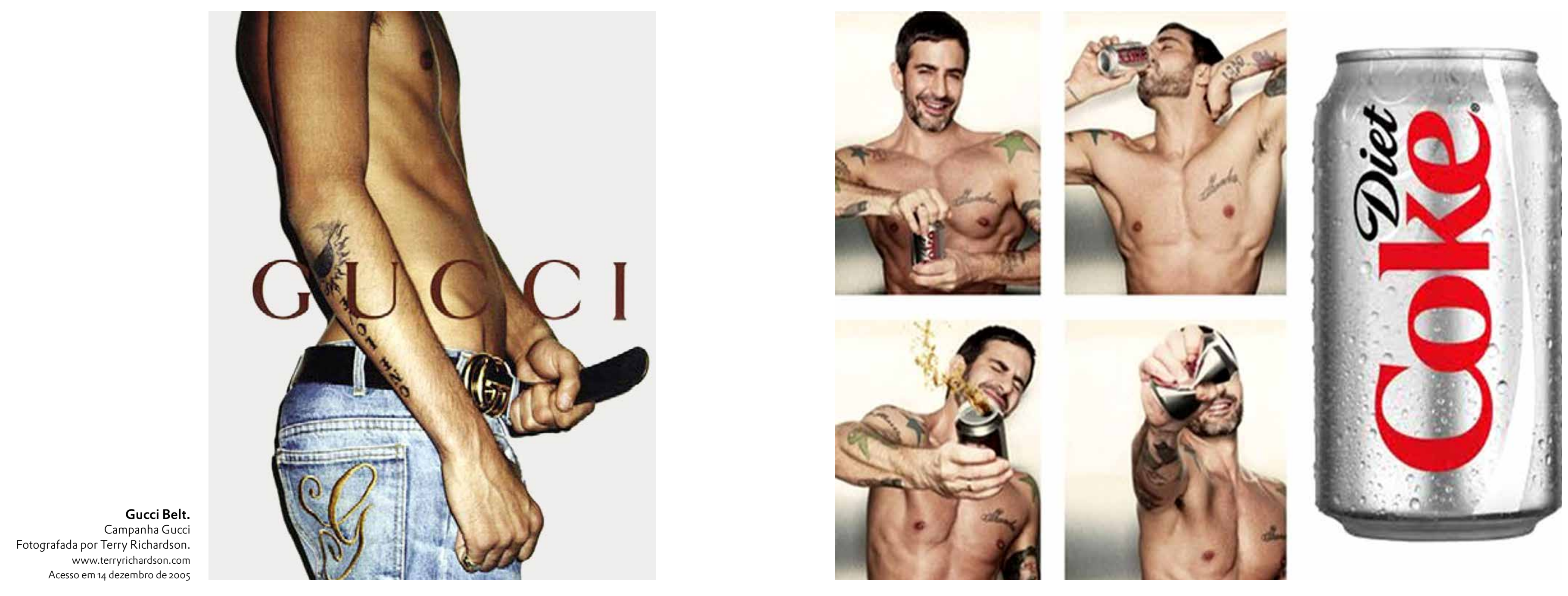

A publicidade promete um futuro desejado: ser amado, Marc Jacobs

invejado, e assim compreende a insatisfação momentânea entre o que o indivíduo é e o que ele gostaria de ser ou Diretor criativo da Diet Coke nnomeação do designer como diretor ciativo já faz parte da campanha. a escolha da personalidade/celebridade parecer ser. Em última instância provoca uma transferência entre a felicidade de ser amado e a ilusão de ser invejado e desejado não pelo que se é, mas pelo que se pode ter. http:///www.fashionfoiegras.com/2013/02/ Acesso em or de dezembro de 2017

Ser proprietário de algo é também uma forma de poder. É um desejo em potência que reforça a imagem com a qual se constrói a identidade, o desenho de subjetividades e de imagens públicas entendidos como instrumentos organizados para definir a percepção do outro sobre mim. Cabe aqui estabelecer relações entre a publicidade, o sujeito desejante e o consumidor como categorias um tanto diferentes. Pode-se desejar nutrir-se de publicidade, sentir inveja e não necessariamente se tornar consumidor. Consumir pode configurar-se como uma 

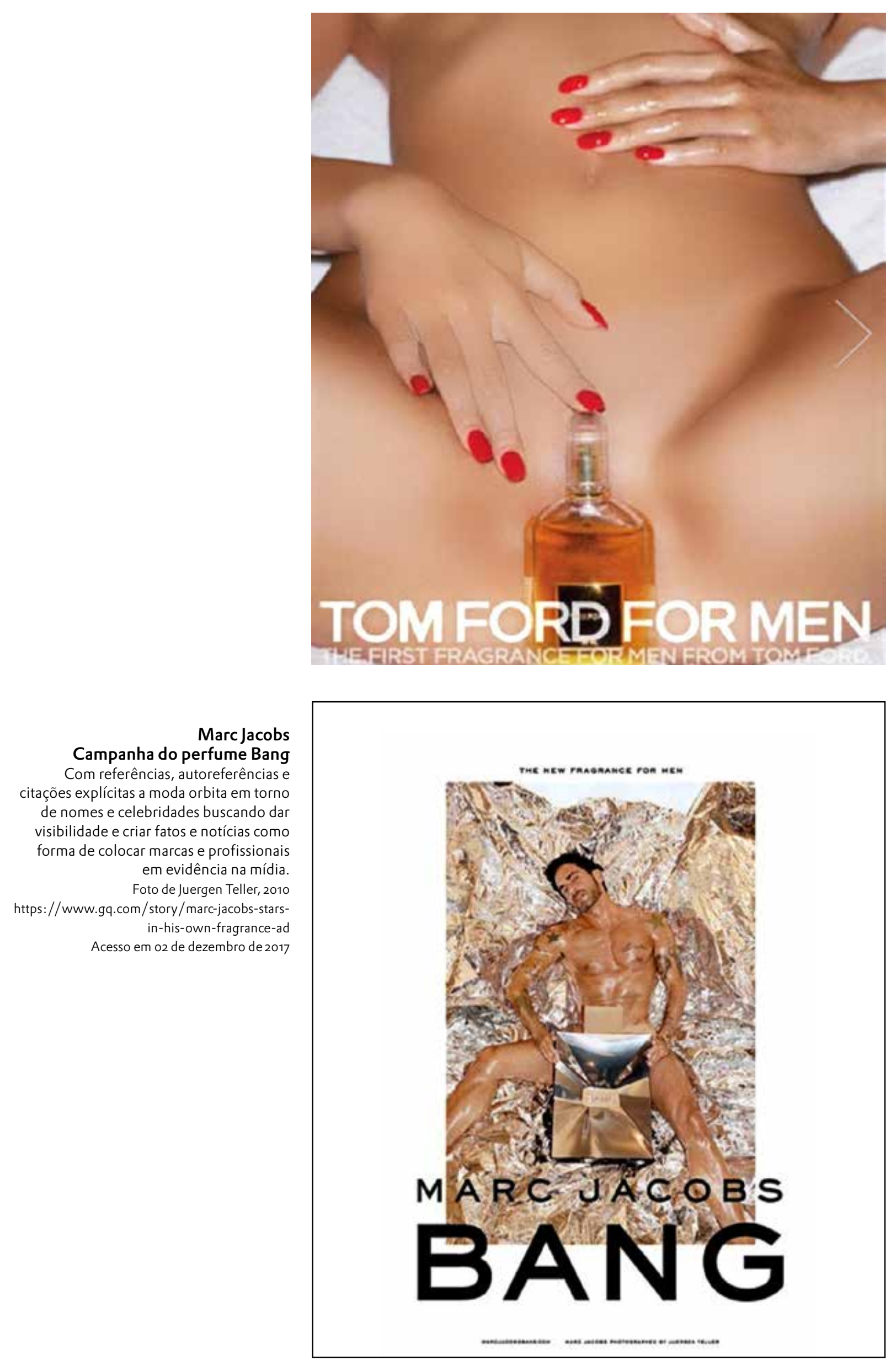

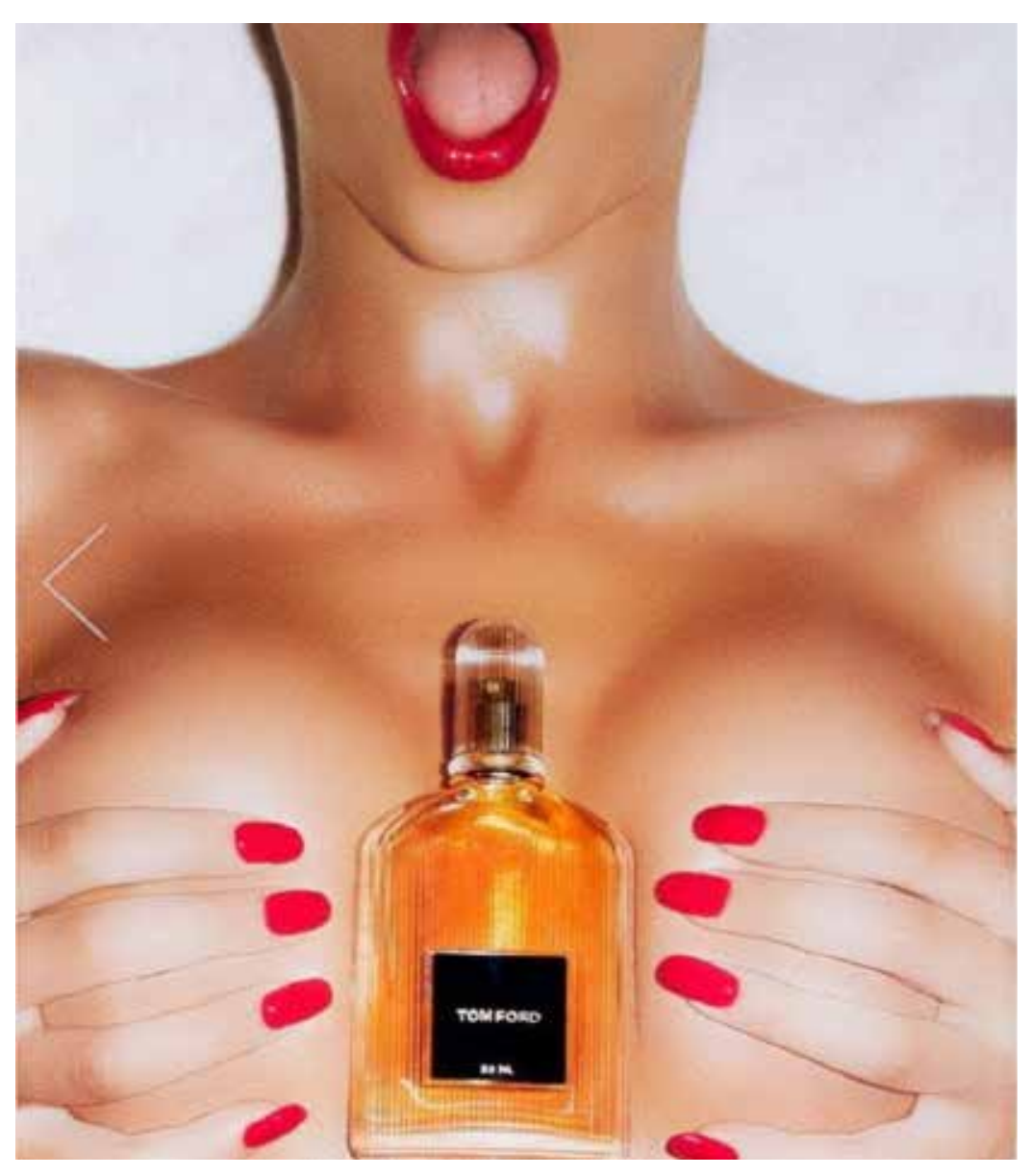

\section{Campanha para perfume}

Fotografada por Terry Hichardson, 2007 Teve a veiculação proibida em diferentes palses. http://www.nydailynews.com/entertainment/ controversial-banned-ads-gallery-
1.22245644? PmSlide 1.2245635 Acesso em 02 dezembro de 2017

para a continuidade de um ciclo desenhado entre os tempos passado, presente e futuro, entre possuir e ser objeto. No universo da moda os referenciais de desejo ficam ainda mais explícitos. Os corpos misturados, a pele à mostra, a sensualidade e a sexualidade são potencializados.

A indústria dos perfumes movimenta milhões e muitas vezes são fortes pilares de posicionamento da marca. Algumas campanhas parecem ser planejadas para causar impacto e polêmica.

O fotógrafo norte-americano Terry Richardson, coloca-se intencionalmente entre o erotismo, a sensualidade e a pornografia. Suas campanhas são deliberadamente ousadas e, no mínimo, causam estranheza. Suas imagens transitam no meio publicitário da moda como estilo cult e de forte personalidade. 


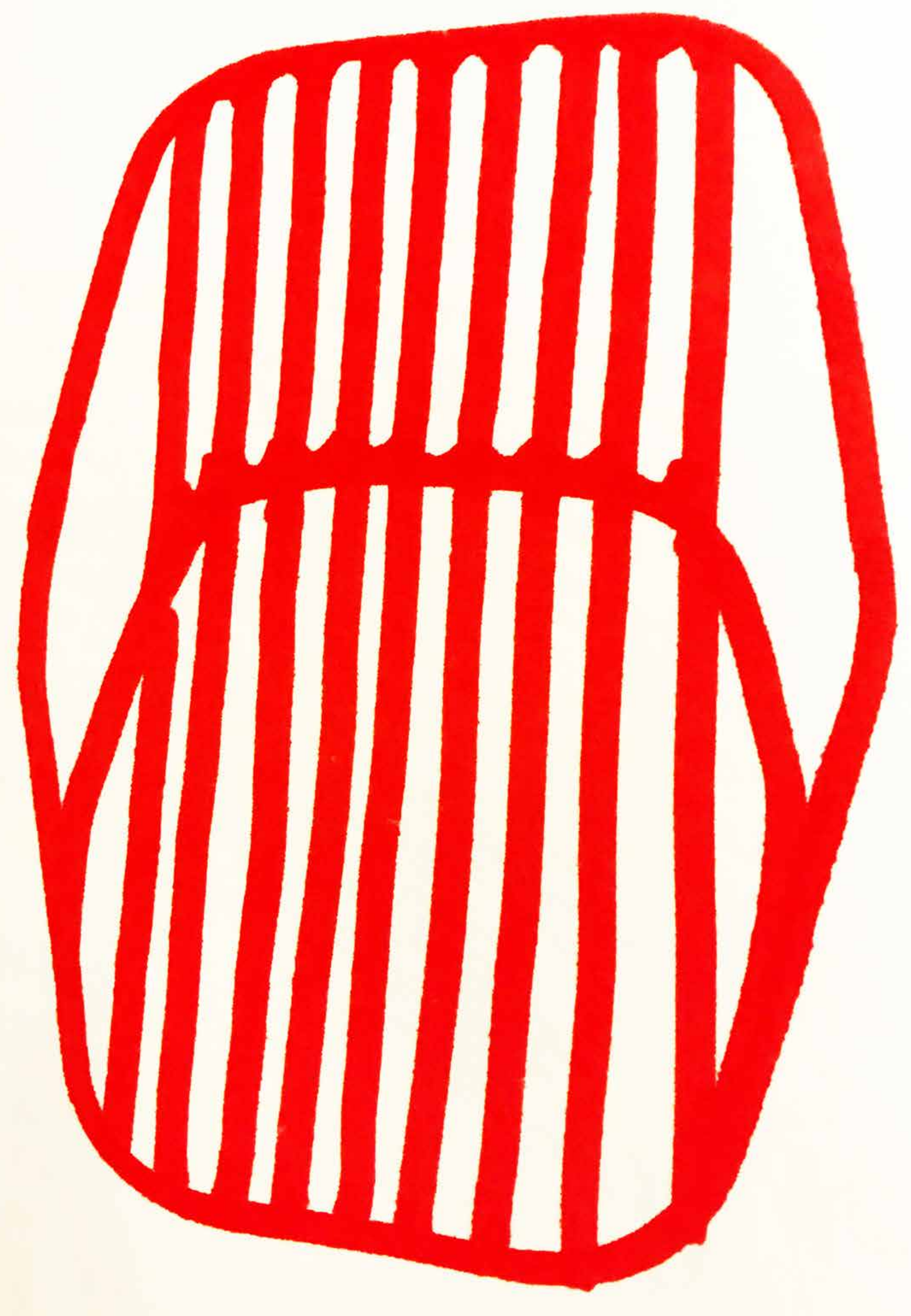

\section{Design e permanência}

Natural $x$ artificial

"Design é compor um poema épico, executar um mural, Design is composing an epic pintar uma obra de arte, escrever um concerto. Mas design poem, executing a mural, também é limpar e reorganizar uma gaveta, extrair um den- painting a masterpiece, write encravado, assar uma torta de maçã, escolher os lados ting a concerto. But design is para um jogo de baseball em um descampado e educar uma also cleaning and reorganicriança. Design é o esforço consciente para impor a ordem zing a desk drawer, pulling com significado". an impacted tooth, baking an apple pie, choosing sides

Traduçõo livre. for a back-lot baseball game, and educating a child. De-

O design, assim apresentado por Papanek, está entre sign is the conscious effort to os desejos de desenhar e construir um futuro melhor impose meaningful order. (utopia) com melhor qualidade de vida para todos e é PAPANEK, 2005, P.3 o estímulo de produção e consumo que contribui, ine- Ronan e Erwan Bouroullec gavelmente com o desenvolvimento econômico na $\begin{gathered}\text { Estudos para cadeira } \\ \text { Drawing, 2012 p.342 }\end{gathered}$ 
geração de renda, empregos etc.. Para Papanek (2005), a produção contemporânea, em sua grande maioria, não leva em conta o projeto sistêmico que considera toda cadeia entre concepção desenvolvimento, distribuição, uso e descarte, numa busca por alternativas de comportamento com menor consumo e maior respeito aos recursos naturais. $\mathrm{O}$ estímulo ao consumo não pode ser excessivo. A sustentação econômica é preocupação constante nas discussões globais de economistas. Resgatado pelos franceses Jacques Grinevald e Ivo Rens, o economista belga Nicholas Georgescu-Roegen, em seu livro Decrescimento (2012), afirma que o verdadeiro produto do processo econômico não é o fluxo material de resíduos - o resultado dos processos industriais, inclusive o produto - mas o fluxo imaterial: a alegria de viver

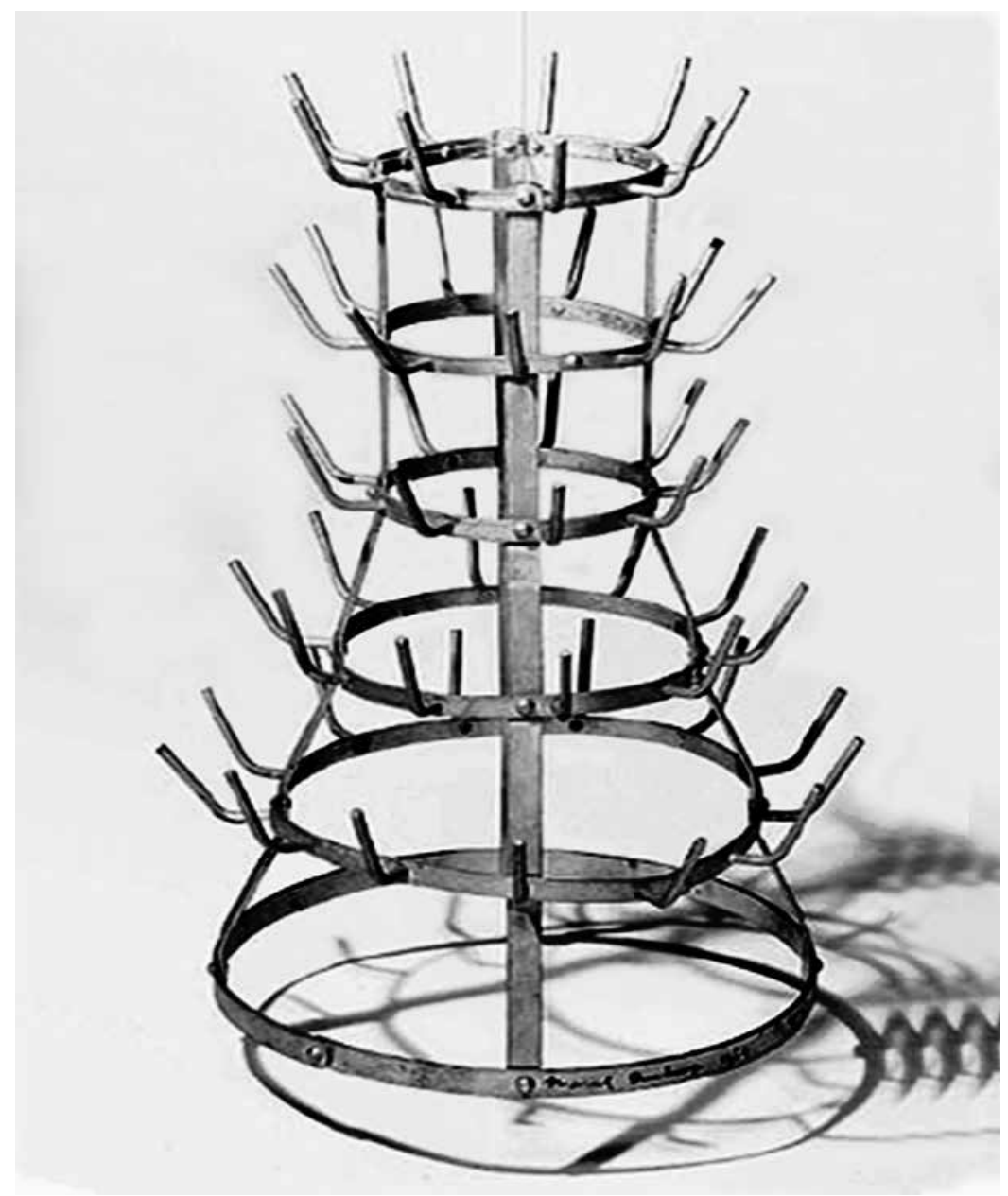

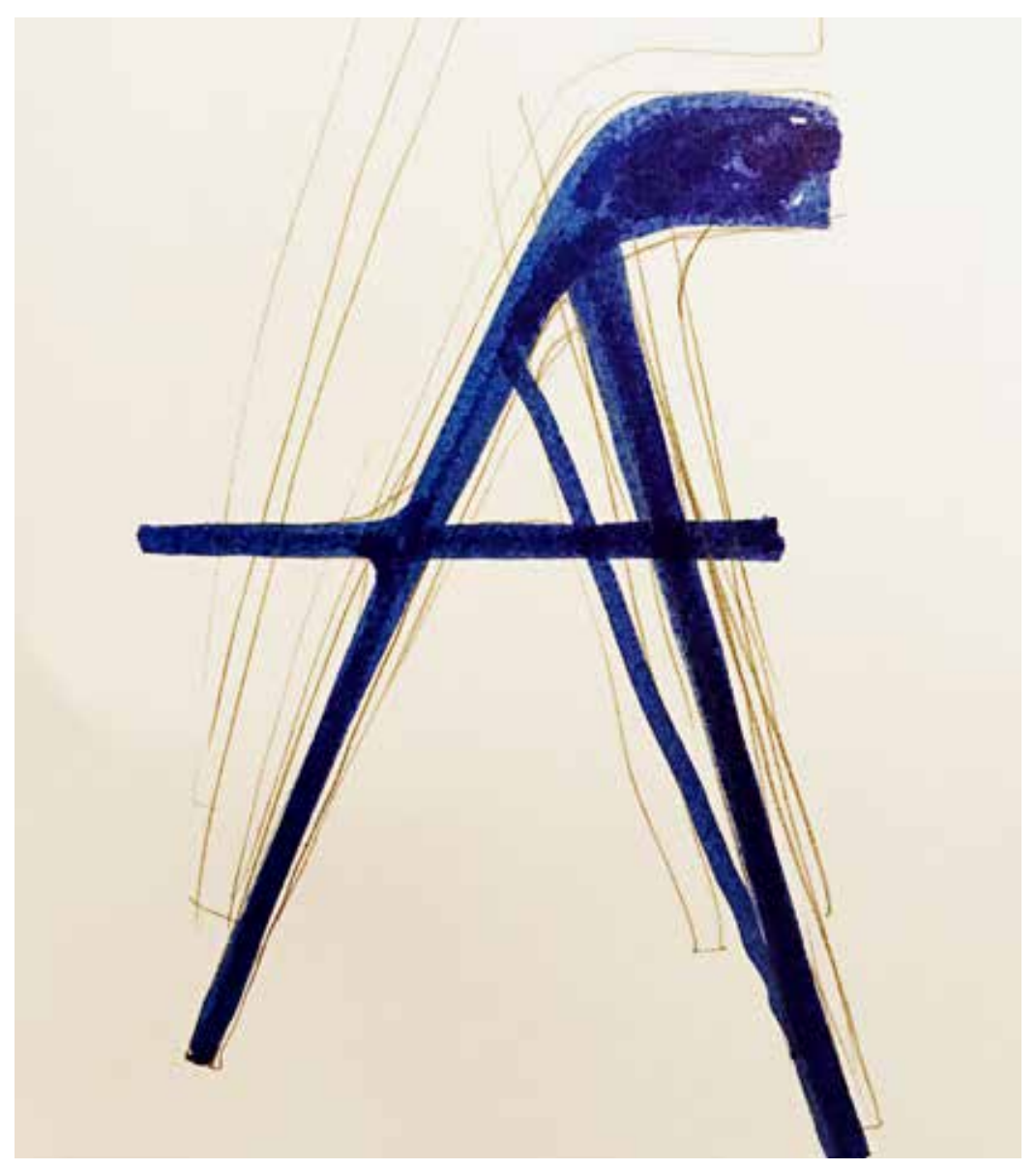

Ronan e Erwan Bouroullec Estudo para cadeir

Para ele, ancorado no conceito de entropia, o desgaste dos recursos naturais será sempre irreversível, a produção industrial e todo processo de entropia servem para o que se chama de qualidade de vida, sempre insustentável. A produção, por mais planejada que seja para otimizar recursos, provocará, de forma irreversível, o consumo de recursos naturais. Para Georgescu-Roegen (2012) a sustentabilidade, muitas vezes utilizada como bandeira de marketing por empresas com distribuição global de produtos, é algo impossível. Acentuam-se então os conflitos entre o desenvolvimento de bens de consumo e a responsabilidade do designer no processo.

\section{PORTE-BOUTEILLES Secador de No limite entre arte e design realizados por Marcel Duchamp em 1914 In: ENCICLLPÉDIA Itaú Cultural de Arte e 2017. Disponivel em: <http://enciclopeda.

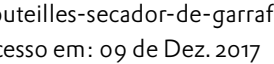




\section{Economia: decrescimento \\ Aceleração e equilíbrio dinâmico}

A abordagem de Georgescu-Roegen não se refere, em primeira análise, ao consumo do mercado de luxo, mas ao consumo cotidiano que considera insustentável.

O sociólogo Hartmut Rosa, em palestra proferida no Sesc São Paulo e no livro Alienation et acceleration (2017), aponta para mudanças comportamentais contemporâ-
neas nas quais a sensação de felicidade está associada a Marcel Duchamp Bicycle Wheel, 1963 Sobreposição e pós-produção,
obra que desencadeou mudanças significativas em conceitos das artes visuais. rivate Collection of Richard Hamilton, Henley-on-Thames liberdade, a velocidade e a aceleração. Para ele, a aceleração de informação e de dados coloca a todos no limite de um abismo.

Esta sensação de incompletude - provocada pela incapacidade humana de absorção e compreensão de informações propagadas de forma exponencial - causa frustração, podendo levar à uma impotência que imobiliza e à depressão. Esse estado de ânimo é reforçado e explorado 


\section{Bruno Munari}

\section{disegnare un albero}

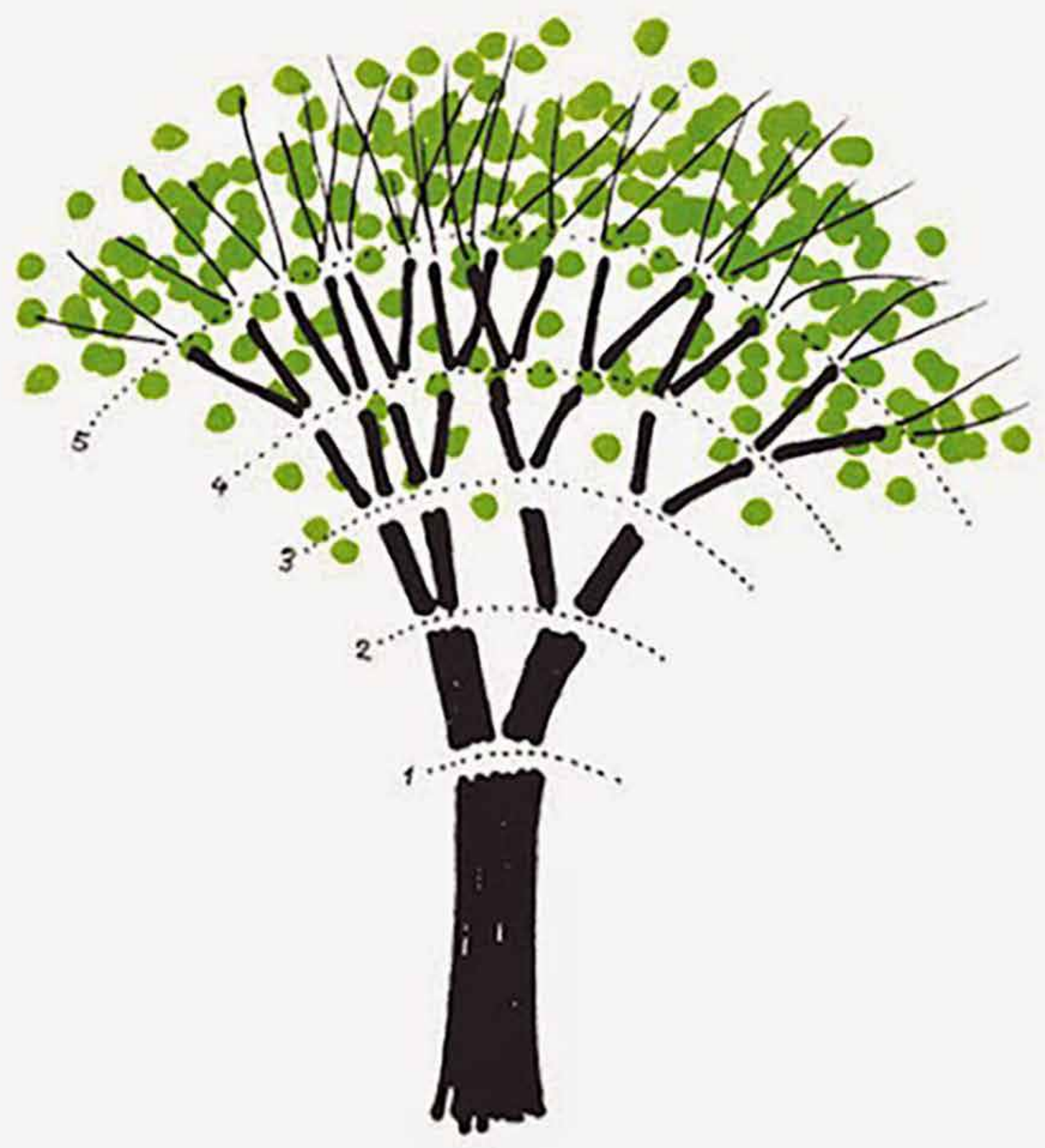

Edizioni Corraini nos mecanismos de estímulo ao consumo.

A comunicação e a publicidade fazem crer que a construção da personalidade e da identidade está associada a hábitos de consumo e reforça a sensação de pertencer a determinados grupos que possuem hábitos semelhantes. Toda cadeia de produção, distribuição e consumo se beneficia desta necessidade de estar up to date no sistema de moda e tem se ampliado para outros setores da economia. Para Rosa (2017), o consumo acelerado tende a sair do controle e desestabilizar a economia global. Segundo ele, é necessário caminhar para a estabilização dinâmica. Este conceito se contrapõe ao de decrescimento do economista Georgescu-Roegen. No decrescimento, toda produção industrial é resíduo e por isso deve ser eliminada. A estabilização dinâmica pressupõe encontrar mecanismos de equilíbrio entre produção e consumo, incluindo aí, toda a produção de informação e de dados.

"A Bauhaus significou um No artigo Design e Crime (2002), Hal Foster retoma o salto qualitativo de uma pensamento de Baudrillard: de que a primeira revolução economia política do proindustrial preparou o pensamento político para a produção duto para uma "economia material. O produto industrial pode levar a pensar sobre as política do signo", em que as definições clássicas da Bauhaus de forma e função, elevando o objeto a objeto signo. Diante da afirmação do filósofo francês de que "o sistema do valor de troca para todo o campo de signos, formas e objetos (...) se modifica em nome do design" (BAUDRILLARD, 1981, p. 186), o objeto desencadeia uma atribuição de valor, além de sua materialidade e além de sua função.

A construção deste objeto-signo, como toda convenção cultural, baseia-se em estratégias de produção, distribuição e comunicação. Parte destes mecanismos é a atribuição de valor, desdeoeconômico atéosimbólico.Aatribuição devalor na cultura contemporânea mistura produtos industrializados, serviços e uma valoração simbólica tornando dificil distinguir os processos envolvidos em cada uma de suas etapas. estruturas da mercadoria e do signo remodelavam uma à outra, de modo que as duas pudessem circular como uma coisa só, como imagem-produto com "valor de troca de signo". FOSTER, 2002, P.53 

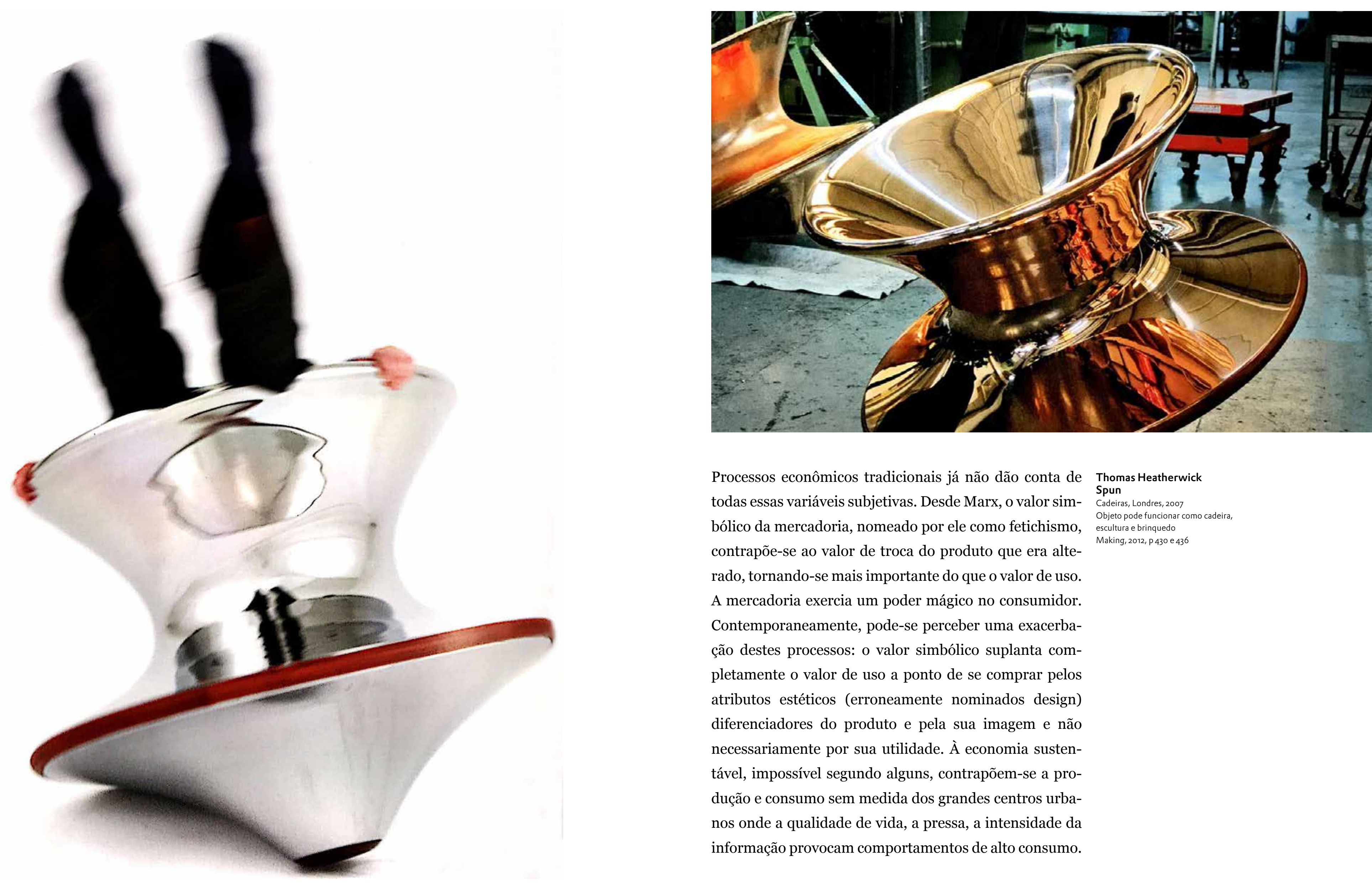

Processos econômicos tradicionais já não dão conta de Thomas Heatherwick todas essas variáveis subjetivas. Desde Marx, o valor simbólico da mercadoria, nomeado por ele como fetichismo, contrapõe-se ao valor de troca do produto que era alteSpun
Cadeiras, Londres, 2007 Objeto pode funcionar como cadeira, rado, tornando-se mais importante do que o valor de uso. A mercadoria exercia um poder mágico no consumidor. Contemporaneamente, pode-se perceber uma exacerbação destes processos: o valor simbólico suplanta completamente o valor de uso a ponto de se comprar pelos atributos estéticos (erroneamente nominados design) diferenciadores do produto e pela sua imagem e não necessariamente por sua utilidade. À economia sustentável, impossível segundo alguns, contrapõem-se a produção e consumo sem medida dos grandes centros urbanos onde a qualidade de vida, a pressa, a intensidade da informação provocam comportamentos de alto consumo. 


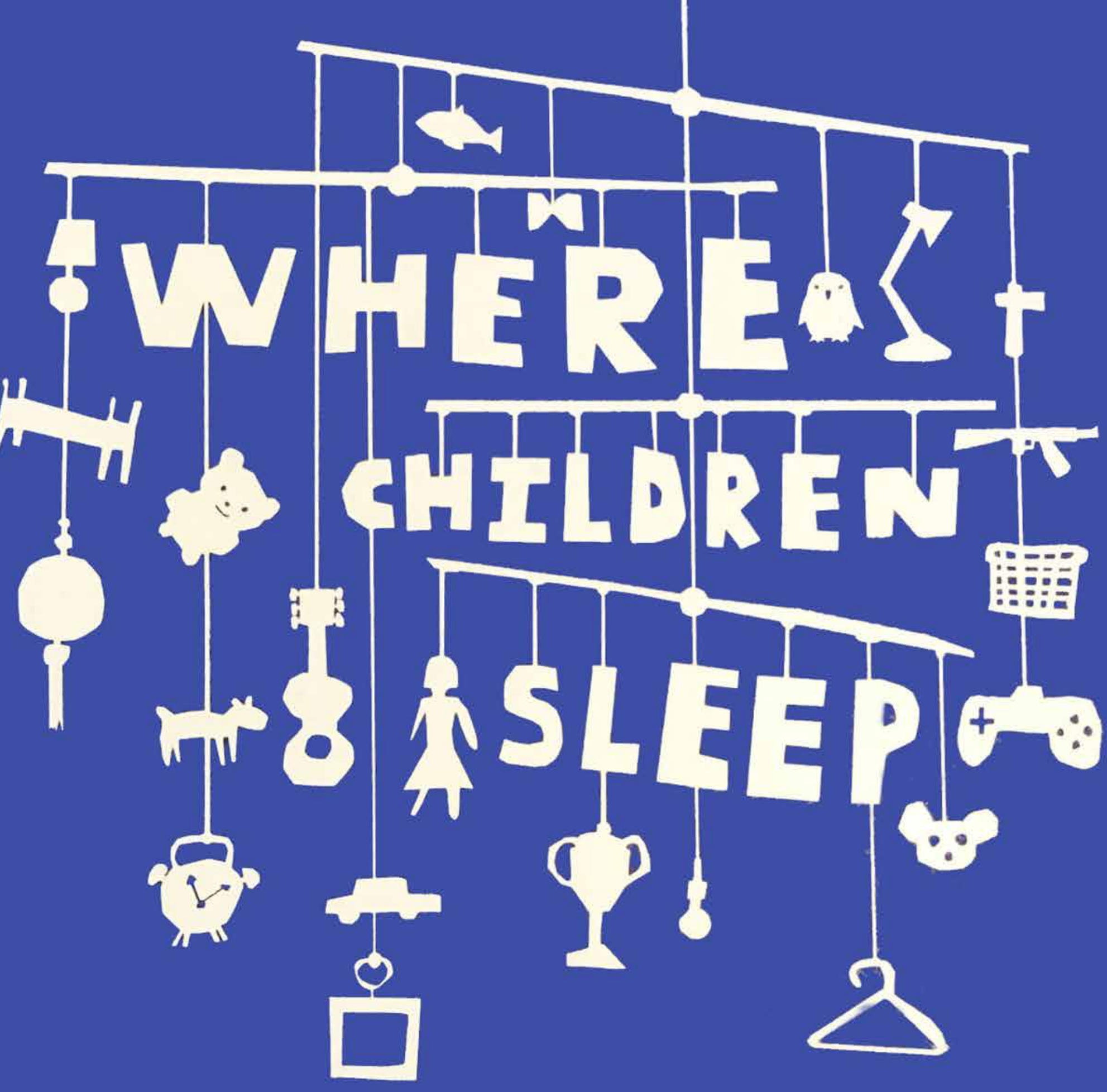

\section{Espaços}

Ambientes e fronteiras

O trabalho do fotógrafo James Mollison, publicado no livro Where Children Sleep (2010), retrata quartos de Where Children Steep crianças de diversos países e nele é possível identificar no qual pode-ser observar comportamentos de consumo e sua relação com contextos sociais distintos. Mollison nasceu no Kenya em 1973, cresceu no Reino Unido onde estudou arte e design na Universidade de Oxford Brookes. Mais tarde morou na Itália e participou de um projeto educacional da marca Benetton chamado Fabrica. Teve trabalhos publicados na revista Colors e no jornal The New York Times.

$O$ registro de quartos infantis com grande contraste entre o excesso de objetos e carência de um mínimo conforto, JAMES MOLLISON pode ter sido influenciado pelo trabalho e pensamento de Oliviero Toscani (Milão, 1942), fotógrafo que assinou por muitos anos as campanhas publicitárias da marca 


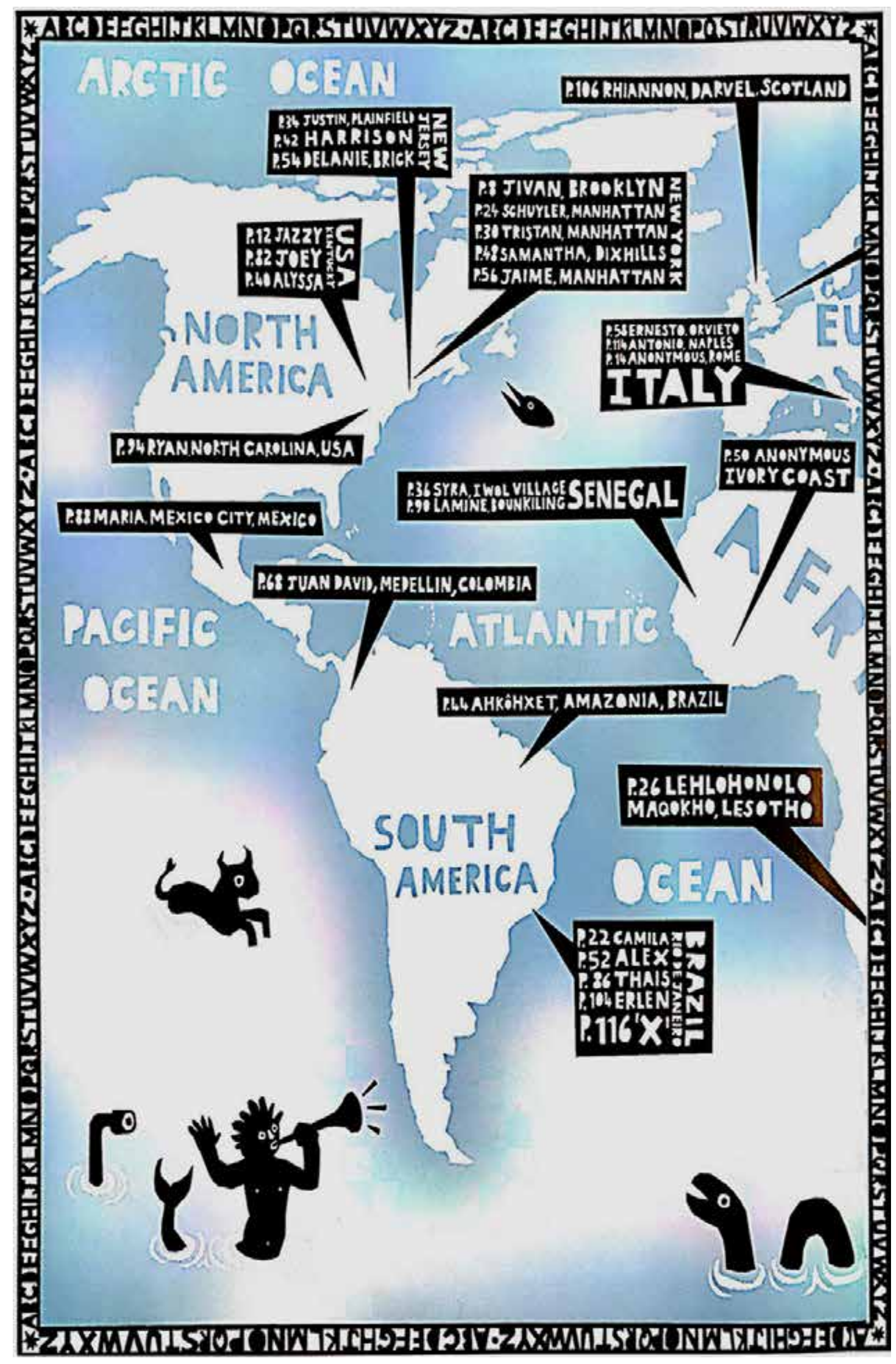

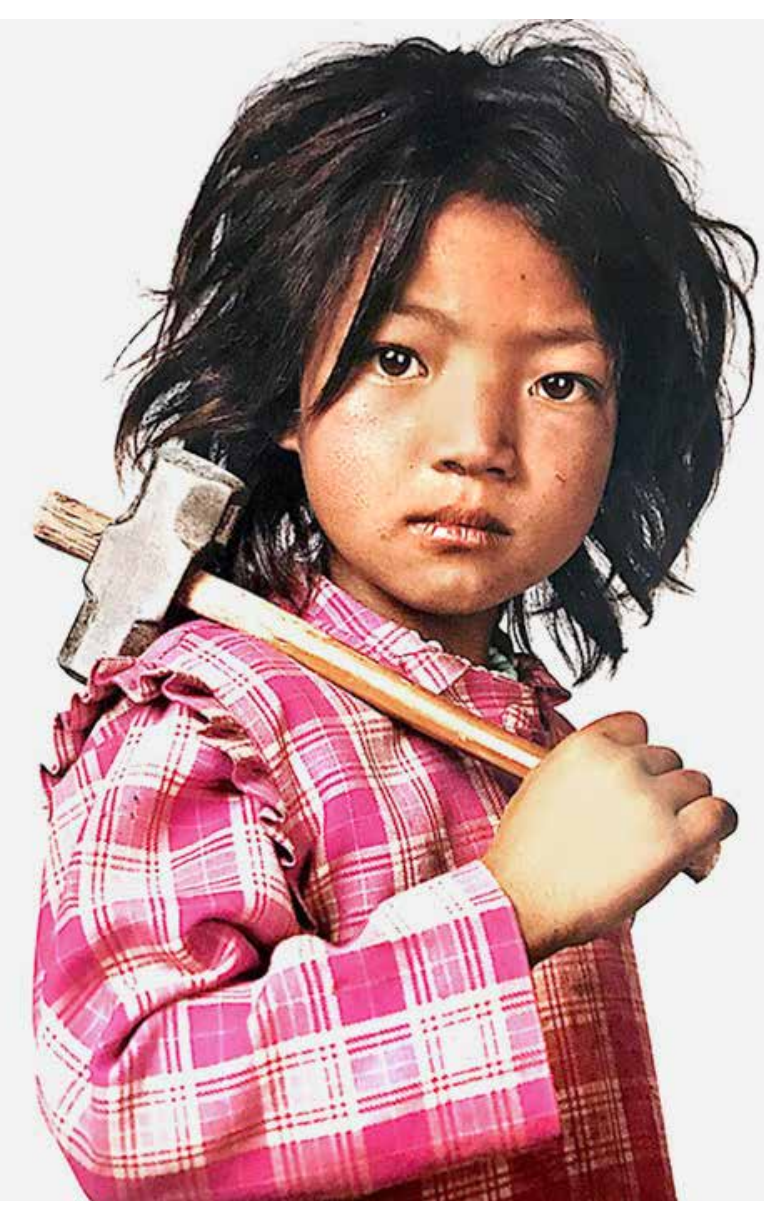

Benetton e que destacou-se pela abordagem de temas polêmicos, tais como sexualidade, religião, preconceitos étnicos, dentre outros.

O projeto iniciou-se em 2004, quando o Centro de Pesquisas Criativas Fabrica da Benetton questionou Mollison sobre a configuração dos ambientes e em especial dos quartos das crianças, e como eles poderiam influenciar o comportamento destas.

Foram visitadas 24 cidades ao redor do mundo e selecionadas 55 crianças e seus respectivos quartos, muitos dos quais compartilhados com toda a família.

Nos registros de Mollison o consumo, à beira da obsessão das meninas do Japão e dos Estados Unidos, contrapõe-se aos quartos austeros e quase inóspitos dos meninos da China e da Cisjordânia.
James Mollison Nepar Londres: Boot, 2010. p. 28

James Mollison Mapa com registro das cidades visitadas 


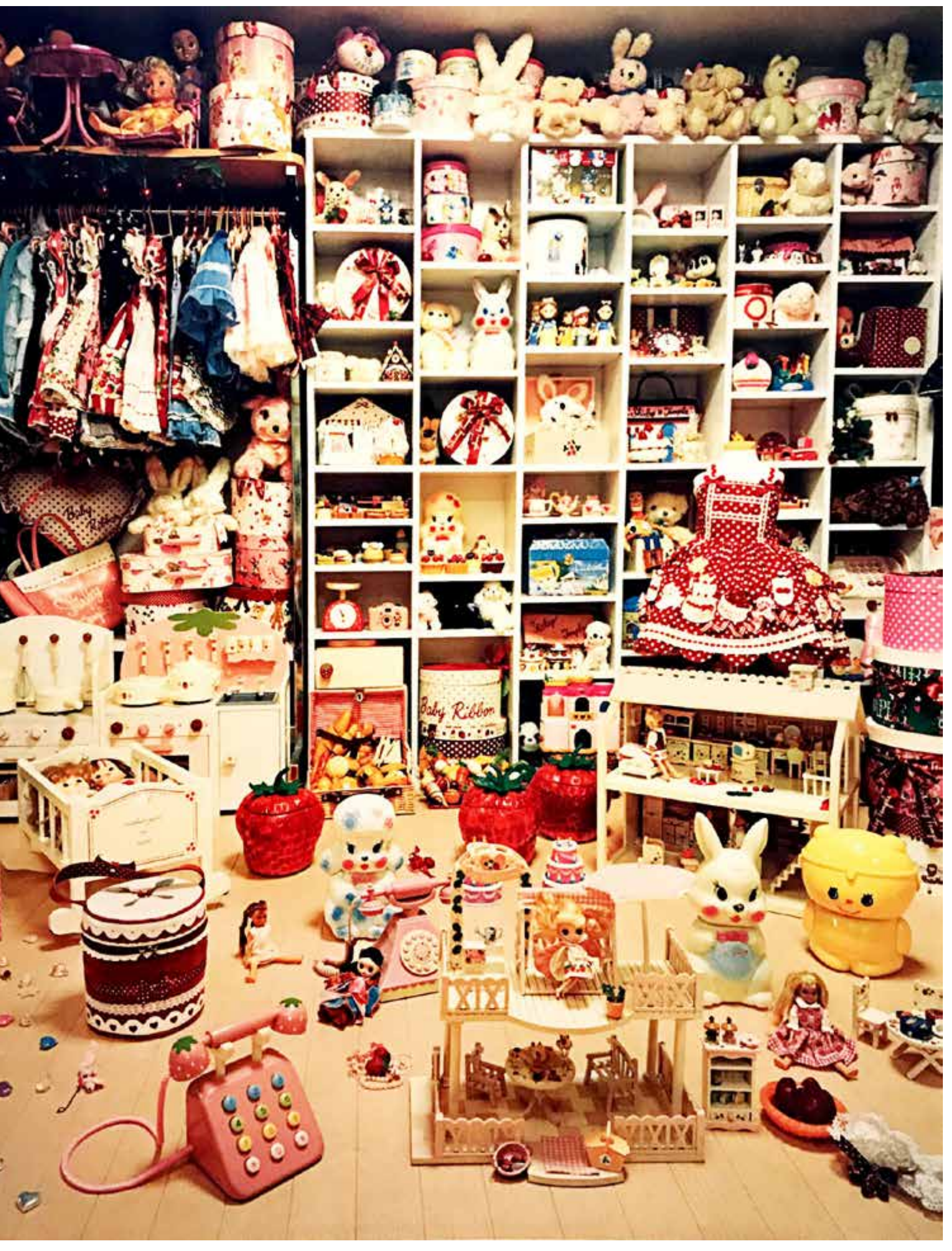

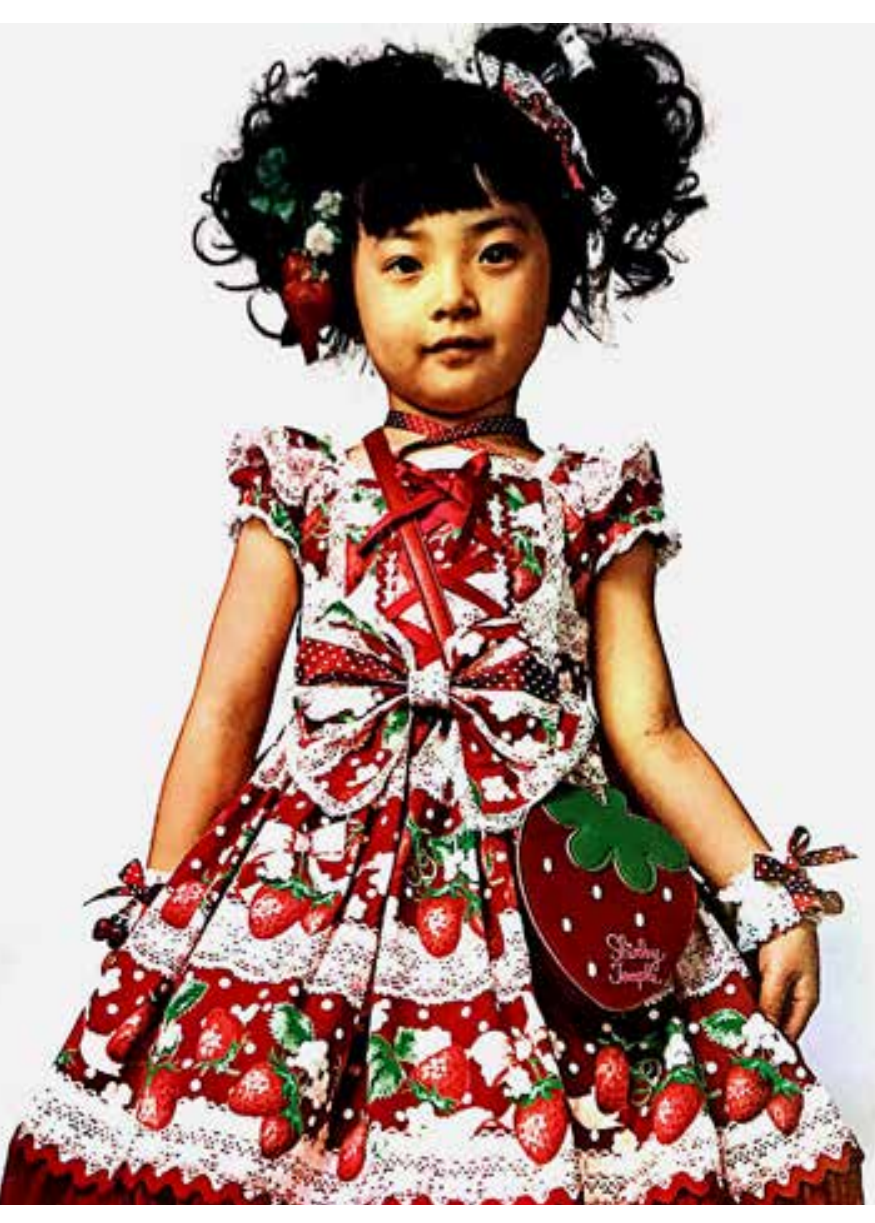

James Mollison Kaye 4 anos viven Sleep Londres: Boot, 2010. p. 10 e 11

Em uma rápida análise das fotografias dos quartos e das crianças: O que é essa abundância no quarto de Kaya? Um quarto vitrine/prateleira, onde os objetos parecem estar expostos não para serem usados, mas para serem vistos, como o que enche os olhos por uma diversidade repetitiva de bichos de pelúcia, caixas com fitas - aparentemente fechadas - e vestidos volumosos como os de personagens de animações televisivas. Um mundo imaginário que parece remeter a um universo dos produtos da comunicação de massa, uma infância moldada por esse modelo especialmente montado para ser consumido. 

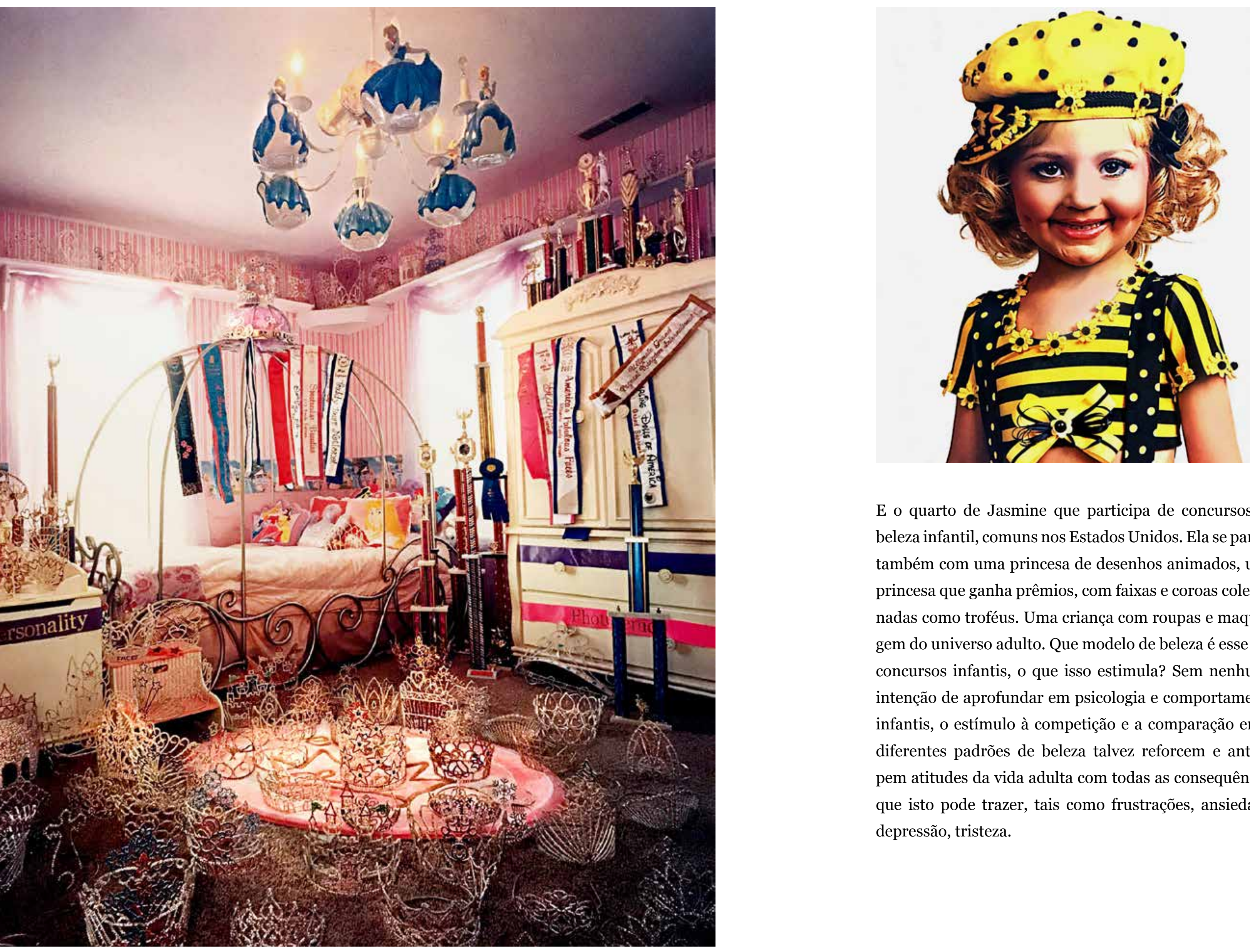

E o quarto de Jasmine que participa de concursos de beleza infantil, comuns nos Estados Unidos. Ela se parece também com uma princesa de desenhos animados, uma princesa que ganha prêmios, com faixas e coroas colecionadas como troféus. Uma criança com roupas e maquiagem do universo adulto. Que modelo de beleza é esse dos concursos infantis, o que isso estimula? Sem nenhuma intenção de aprofundar em psicologia e comportamento infantis, o estímulo à competição e a comparação entre diferentes padrões de beleza talvez reforcem e antecipem atitudes da vida adulta com todas as consequências que isto pode trazer, tais como frustrações, ansiedade, depressão, tristeza. 


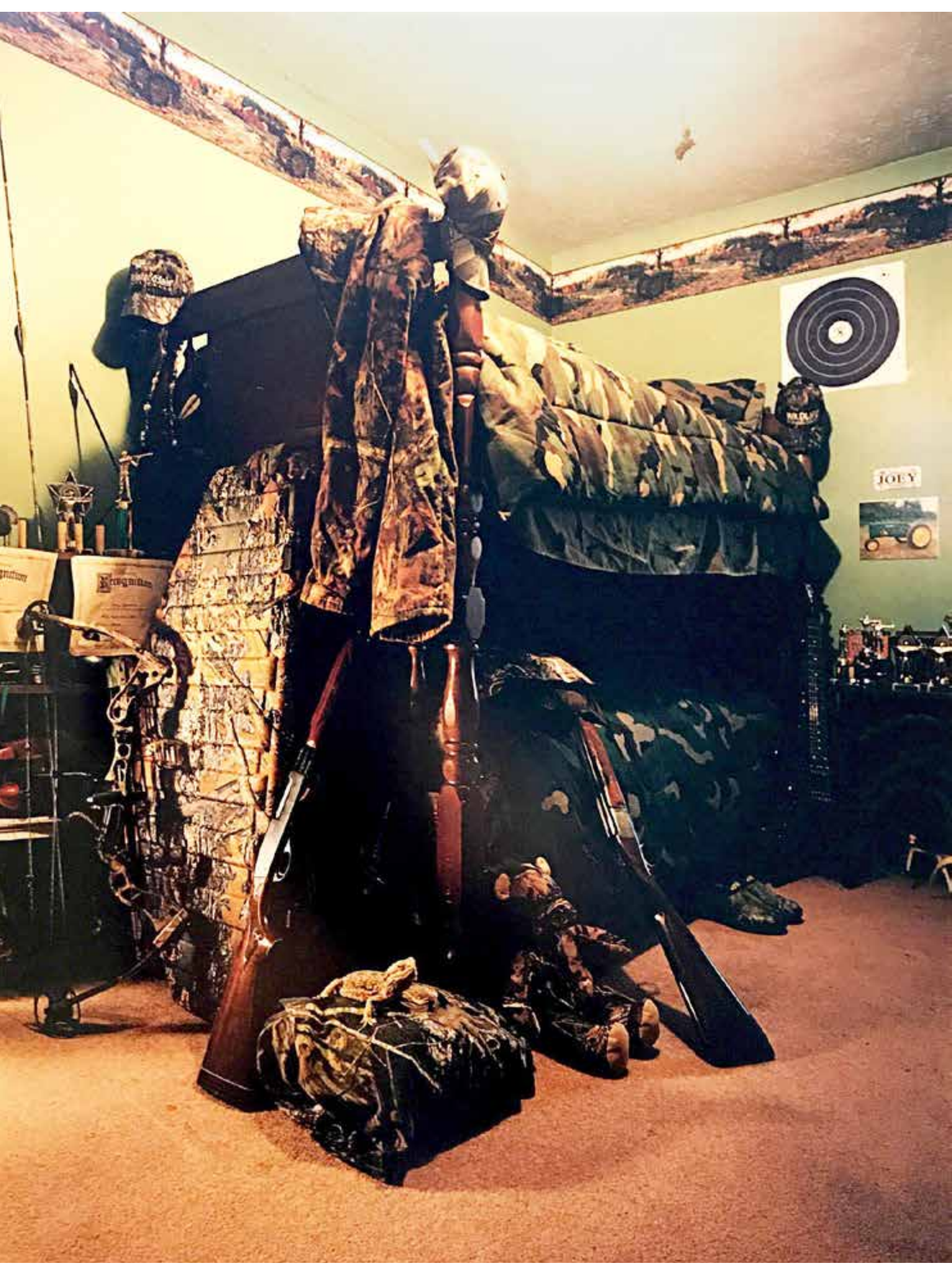

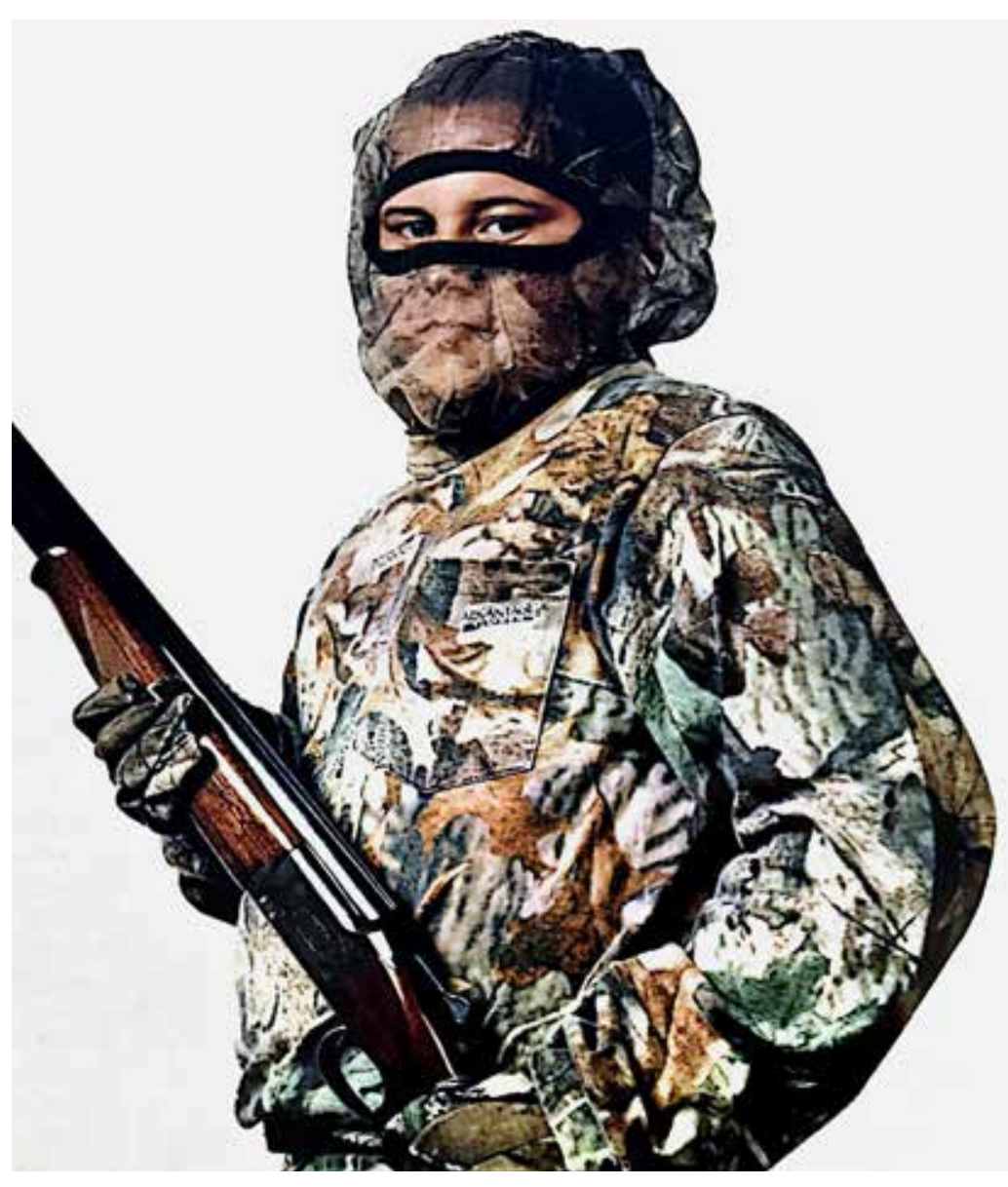

James Mollison Joey, 11 anos, vive em Kentucky, EUA Londres: Boot, 2010. p. 82 e 83

O quarto de Joey, ao contrário do contraste anterior, combina muito com ele. Vestido para combate, sua roupa e seu quarto são feitos com material de camuflagem de guerra. Além da roupa, ele ostenta, uma arma e um modo um pouco agressivo de olhar, como um enfrentamento. A coragem poderia ser uma atributo de qualidade em uma pessoa tão jovem, mas não é essa impressão a que fica ao se pensar que é uma criança de 11 anos, preparada para um conflito.

Seu quarto reforça essa sensação. Montado para a guerra, os objetos se misturam com forte apelo de esconderijo. Até mesmo o ursinho de brinquedo está com máscara e vestimenta de proteção. Os adesivos da parede retratam tanques de guerra e papéis para treino de tiro ao alvo. 



Por fim, o quarto de Hamdi talvez seja ainda mais triste: nada nele diz algo sobre o seu ocupante, a não ser sobre sua cultura. Talvez o boneco seja o que mais perto está de quem é esse menino. A escassez aqui é condição de vida, uma vida em transição. Esse quarto é de qualquer um afinal. A desigualdade de posses talvez tenha também uma relação direta com a importância dos meios de comunicação e do acesso à publicidade global.

Escassez e abundância complementam-se na linha do tempo? Nesse tempo da publicidade, da ansiedade e dos prazeres efêmeros, a comunicação provoca o desejo pela posse na mesma medida? A luta pela sub-existência e a "alegria de viver" da qual fala Georgescu-Roegen (2012) coexistem? O que parece instigante, no momento, não é uma abordagem de contextos políticos, mas os estímulos de consumo, a abundância e a escassez. 
A somber study of mortality, and an extension of mueck's hyperrealistic sculptural practice, 'mass' draws from the biological structure of the skull, regarded by him as extraordinary facets of humanity.

The installation brings to mind the massed remains in the catacombs of paris, an imposing wall of human heads that resonates with a simultaneous and strange sense of impermanence

\section{Design e caos \\ Métodos projetuais complexos}

"Um estudo sombrio da mortalidade e uma extensão da prática escultórica hiperrealista de Mueck, a "massa" desenha a estrutura biológica do crânio, considerada por ele como facetas extraordinárias da humanidade. A instalação traz à mente os restos amontoados nas catacumbas de Paris, um imponente muro de cabeças humanas que ressoa com um sentimento simultâneo e estranho de impermanência e eternidade. Em Mass, Mueck comemora a forma que une toda a humanidade e presta homenagem a um símbolo que se inseriu na arte de todas as culturas e religiões. Cercado por caveiras cobrindo quase todas as paredes da galeria, os visitantes são lembrados da transitoriedade da vida." and eternality.

In 'mass', mueck celebrates the form that links all humanity, and pays homage to a symbol that has stood

within the art of essentially ll cultures and religion surrounded by skulls covering nearly every surface of the walls, visitors are reminded of the transience of life. mueck-national-gallery-victoria-triennialmass-12-15-2017/
Acesso em 17 de dezembro de 2017

\section{Ron Mueck}

National Gallery Victoria,

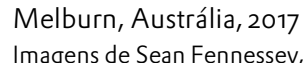
https://www.designboom.com/art/ronmueck-national-gallery-victoria-triennialmass-12-15-2017/ Acesso em 17 de dezembro de 2017 

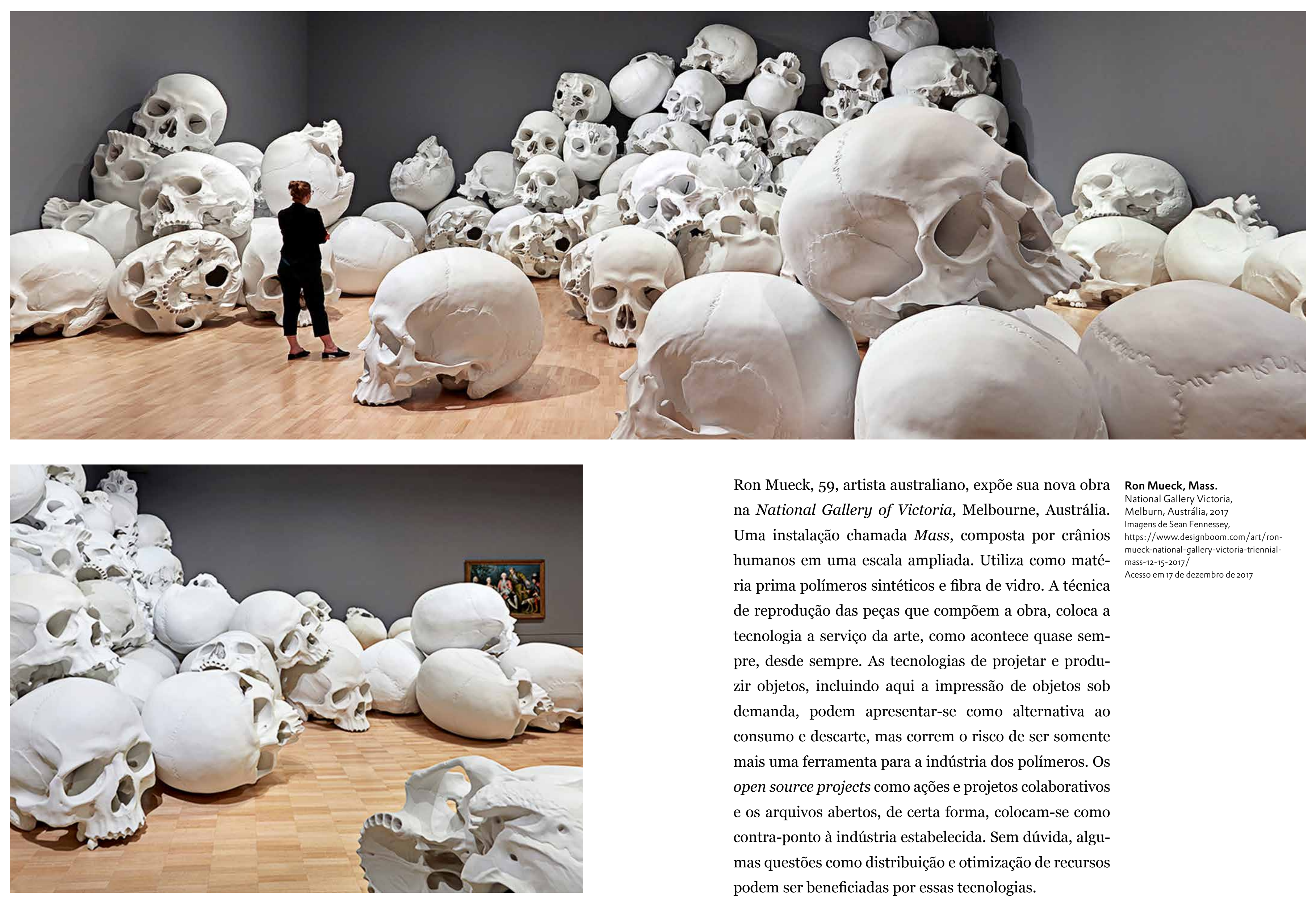

Ron Mueck, 59, artista australiano, expõe sua nova obra Ron Mueck, Mass. na National Gallery of Victoria, Melbourne, Austrália. Melburn, Austrália, 2017 Uma instalação chamada Mass, composta por crânios humanos em uma escala ampliada. Utiliza como matéria prima polímeros sintéticos e fibra de vidro. A técnica Imagens de Sean Fennessey, intps://www.designboom.com/art/ron mass-12-15-2017/ de reprodução das peças que compõem a obra, coloca a tecnologia a serviço da arte, como acontece quase sempre, desde sempre. As tecnologias de projetar e produzir objetos, incluindo aqui a impressão de objetos sob demanda, podem apresentar-se como alternativa ao consumo e descarte, mas correm o risco de ser somente mais uma ferramenta para a indústria dos polímeros. Os open source projects como ações e projetos colaborativos e os arquivos abertos, de certa forma, colocam-se como contra-ponto à indústria estabelecida. Sem dúvida, algumas questões como distribuição e otimização de recursos podem ser beneficiadas por essas tecnologias. 

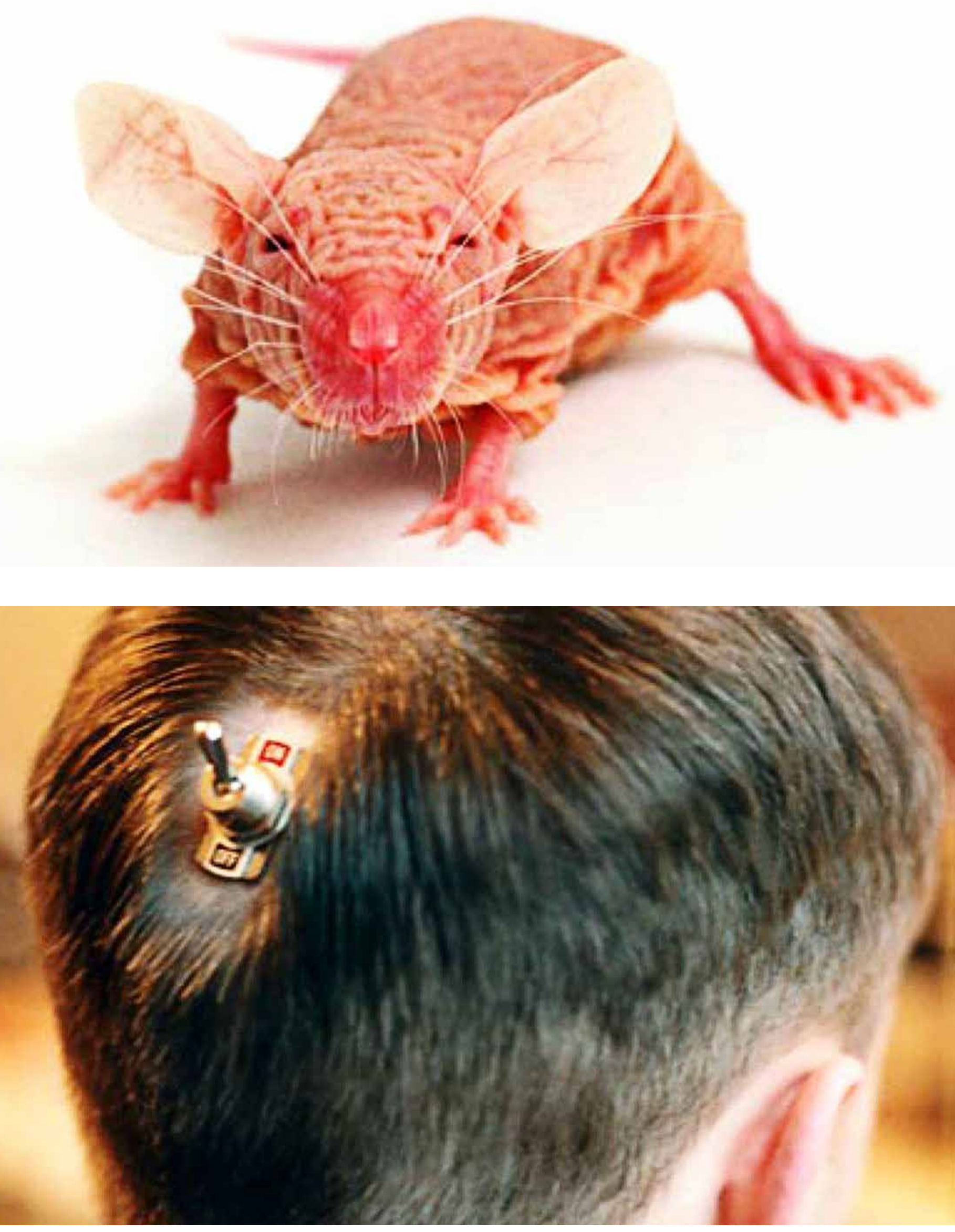

Considere-se também o avanço de pesquisa de impressões e cultura de tecidos vivos e as contribuições que podem surgir no campo das ciências biológicas.

Em exposição realizada em 2006 na cidade de Saint Etienne, na França, as questões éticas de manipulação genética e o design de seres vivos foram apresentadas:

Eden ADN: design du vivant.

Une brebis, trois lettres et un scénario catastrophe. En 1996, Dolly faisait entrer l'A.D.N. dans le langage courant avec le fracas propre aux révolutions et envahissait le paysage médiatique de ses possibilités futures : clonage humain en tête (sa perspective la moins crédible, mais la plus effrayante). Le vivant devenait soudain compréhensible par le commun des mortels comme un gigantesque lego génétique, bientôt manipulable selon tous nos désirs fonctionnels, voire décoratifs : une matière à design presque comme une autre. Les robots, jusqu'alors seule préfiguration populaire du mythe de Frankenstein, étaient presque relégués au rang de vieillerie post-industrielle. Si l'imitation et la reproduction de la vie restaient fascinantes dans leur version mécanique, nous allions enfin pouvoir créer de véritables organismes vivants! Dans le cadre de la cinquième Biennale Internationale Design Saint-Étienne, Eden ADN interrogera la manipulation de la vie par l'homme et l'imbrication toujours plus prégnante entre objet et vivant qui en résulte. Ce sont deux concepts faussement paradoxaux, scandaleusement fusionnels pour certains, que la robotique illustre depuis la révolution industrielle et que la révolution biotechnologique a irrémédiablement bouleversé durant ces dix dernières années.

Eden DNA: design de seres vivos. Uma ovelha, três letras e um cenário de desastre. Em 1996, Dolly trouxe
Eden ADN: design du vivant Curadoria:

Anthony van den Bossche Saint Etienne, Françą, 2006
http: //www.bibennale-design.com/saintetienne/2006/home.html Acesso em 17 de dezembro de 2017 


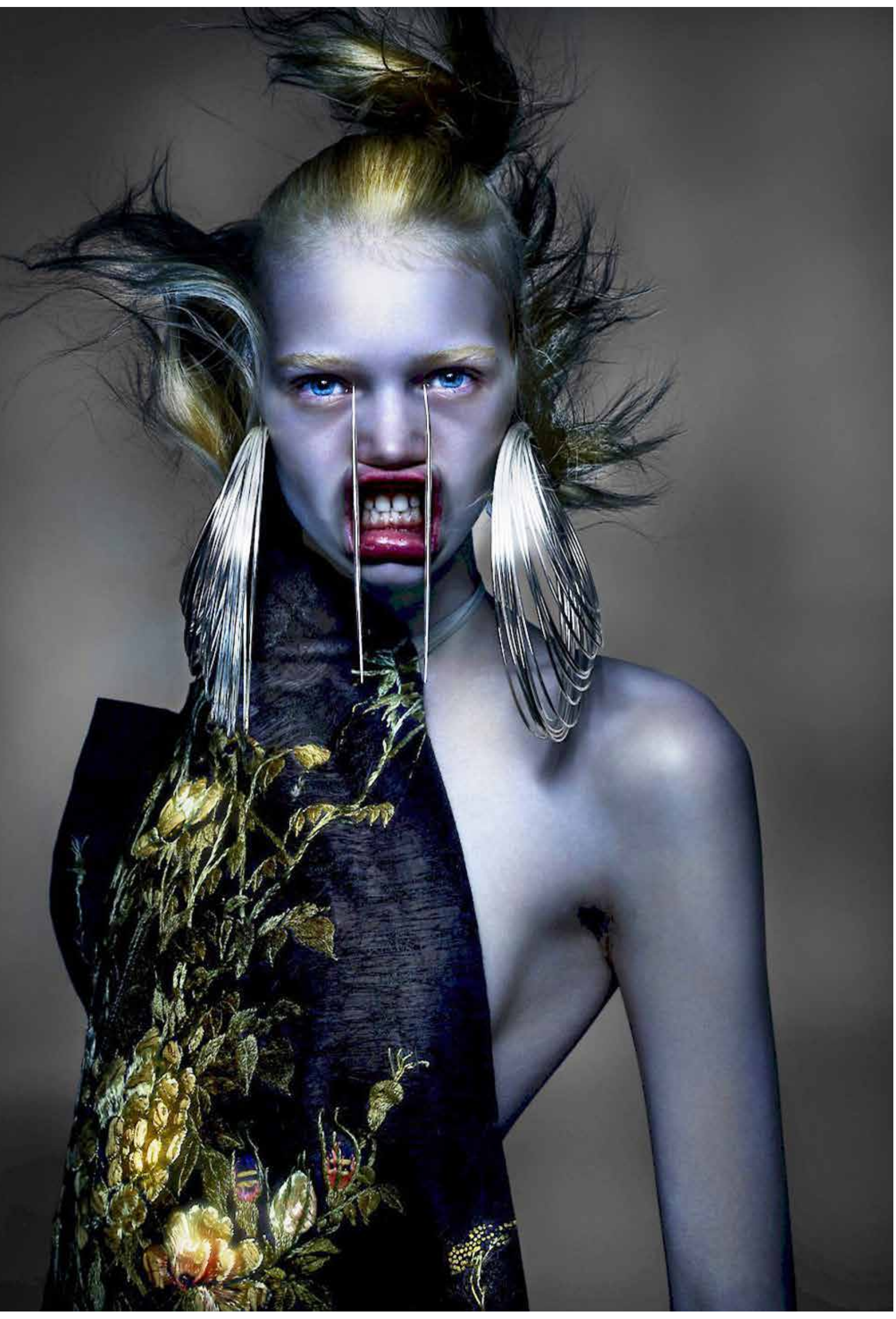

o DNA para a linguagem cotidiana com o rugido das revoluções e invadiu a paisagem da mídia com suas possibilidades futuras: a clonagem humana em mente (sua perspectiva menos passível de crédito, mas assustadora). A vida tornou-se repentinamente compreensível pelos mortais comuns como um lego genético, logo manipulável de acordo com todos os nossos desejos funcionais, mesmo estético: uma questão de design quase como qualquer outro. Robôs, até então, a única configuração popular do mito de Frankenstein, foram quase relegados ao posto de velhice pós-industrial. Se a imitação e a reprodução da vida continuassem fascinantes em sua versão mecânica, finalmente seríamos capazes de criar verdadeiros organismos vivos! Como parte da Quinta Bienal Internacional de Design Saint-Etienne, Eden ADN questiona a manipulação da vida pelo homem e a imbricação cada vez maior entre o objeto e o viver que dele resultada. Estes são dois conceitos falsamente paradoxais, escandalosamente funcional para alguns, que a robótica vem ilustrando desde a revolução industrial e que a revolução biotecnológica modificou irreparávelmente nos últimos dez anos.

Tradução livre

O homem contemporâneo está irremediavelmente cercado pelo mundo dos objetos, quer estes tenham ou não deslocamentos de função, ou sejam ressignificados. Neste aspecto, faz sentido a afirmação de Flusser sobre ter sido criado um mundo artificial. Consumir parece um ato em potência e o habitante das grandes cidades é quem mais o realiza. Deste modo, todos são virtualmente consumidores, mas só alguns conseguem realizar seu potencial de consumo. Mesmo que não se possa comprar, as pessoas podem apropriar-se simbolicamente desses objetos, consumi-los simbolicamente também por meio de suas imagens.

Nick Knight e Katy England Ototógrafo Knight se associa a estilista Es pecas de racrimaginar algumas Alexander McQueen dos anos 90 http: // www.anothermag.com/
Acesso em 13 de janeiro 2018 

ais está-se entendendo que os limites entre os campos de conhecimento e de produção estão esgarçados, do mesmo modo que a relação sujeito/objeto, arte/ciência/ design, natureza/cultura, assim como outros pares ou tríades que são parte de discurso e de uma prática de normatização e de construção de significado que buscam certezas e "acertos", tanto pela perspectiva conceitual quando pela perspectiva do fazer, como se teoria e prática, projetar e produzir fossem ontologicamente distintos. Ao se pensar no consumo, na arte e no design está se tratando de linhas que se encontram em pontos diversos, como sobreposições, idas e vindas num desenho que se assemelha menos a uma rede do que a um emaranhado de texturas e experiências que trazem de volta os erros, as iterações, os testes, um processo que se abre, até que, obrigatoriamente, se chega a sensação de incompletude e quase nunca à finalização de algo.

Objetivamente, a posse de um objeto de luxo, como uma Breakfast at Tiffany's, 1961 Filme de Blake Edwards,
baseado em romance de

bolsa da marca Louis Vuitton é desnecessária mas, num processo de assimilação e memória, quando se fala de Audrey Hepburn usando um objeto de marca, o produto está sendo consumido e aqui ele talvez seja mais signo do que nunca. O consumo da imagem, real, digital, ou imaginada é consumo. Talvez por isso, outras estratégias têm sido criadas nas campanhas publicitárias como o recurso de desenvolver narrativas que muitas vezes envolvem celebridades. A memória desencadeia sequencias de imagens, não como fotogramas desordenados, mas cenas e fragmentos de movimentos. A fidelidade à marca constrói-se nessa mistura de memória e vida. 


\section{Arte e Design}

Intenção e projeto

O projeto Infinity Kusama da marca Louis Vuitton teve Yayoi Kusama à frente o designer Marc Jacobs. Num processo entre NARRATTEMORRIS, 2014, P.79 apropriação e assinatura conjunta, o trabalho original da artista japonesa Yayoi Kusama (1929) transformou-se em uma série limitada de produtos de luxo. Bolsas, acessórios, tecidos, malas de viagem etc. ganharam cores e formas que remetem diretamente à obra da artista apresentada na década de 60 em Nova York.

Em vídeo de divulgação, veiculado em maio de 2012 e disponível ainda hoje no canal Youtube, Jacobs declara-se encantado pela obssessão de Kusama por círculos desordenados e de diferentes tamanhos que compunham telas e instalações criadas pela artista. A equipe de designers e produtores, coordenados por Jacobs, tratou de "traduzir" as obras originais em estampas, cores e padrões para que 



fossem multiplicados em produtos de tecidos e couro. A Yayoi Kusama

energia das "bolinhas" de Kusama, as cores vibrantes e Infinity mirror room(detalhe)

sua "obssessão infinita” remetem, para Jacobs, ao com-

portamento contemporâneo instável, agitado, inquieto,

ansioso. Para ele, sua versão da padronagem é fácil de

usar. O dinamismo da estampa é a forma encontrada pela

Phallis Field, 1965

À esquerda
Yayoi Kusam

relações e seu ambiente.

As formas fálicas e sobrepostas da obra original da artista criadas em 1965 são traduzidas em cilindros com as pontas arredondadas e que lembram tentáculos, talvez mais simples e de fácil leitura para um público maior e sem a inconveniência de provocar uma interpretação erotizada da obra. Os círculos originais, organizados de forma simétrica ou orgânica, são agora distribuídos sistematicamente. As diferentes escalas e a variação de cores, parecem também reorganizadas para adequarem-se a cada uso. 


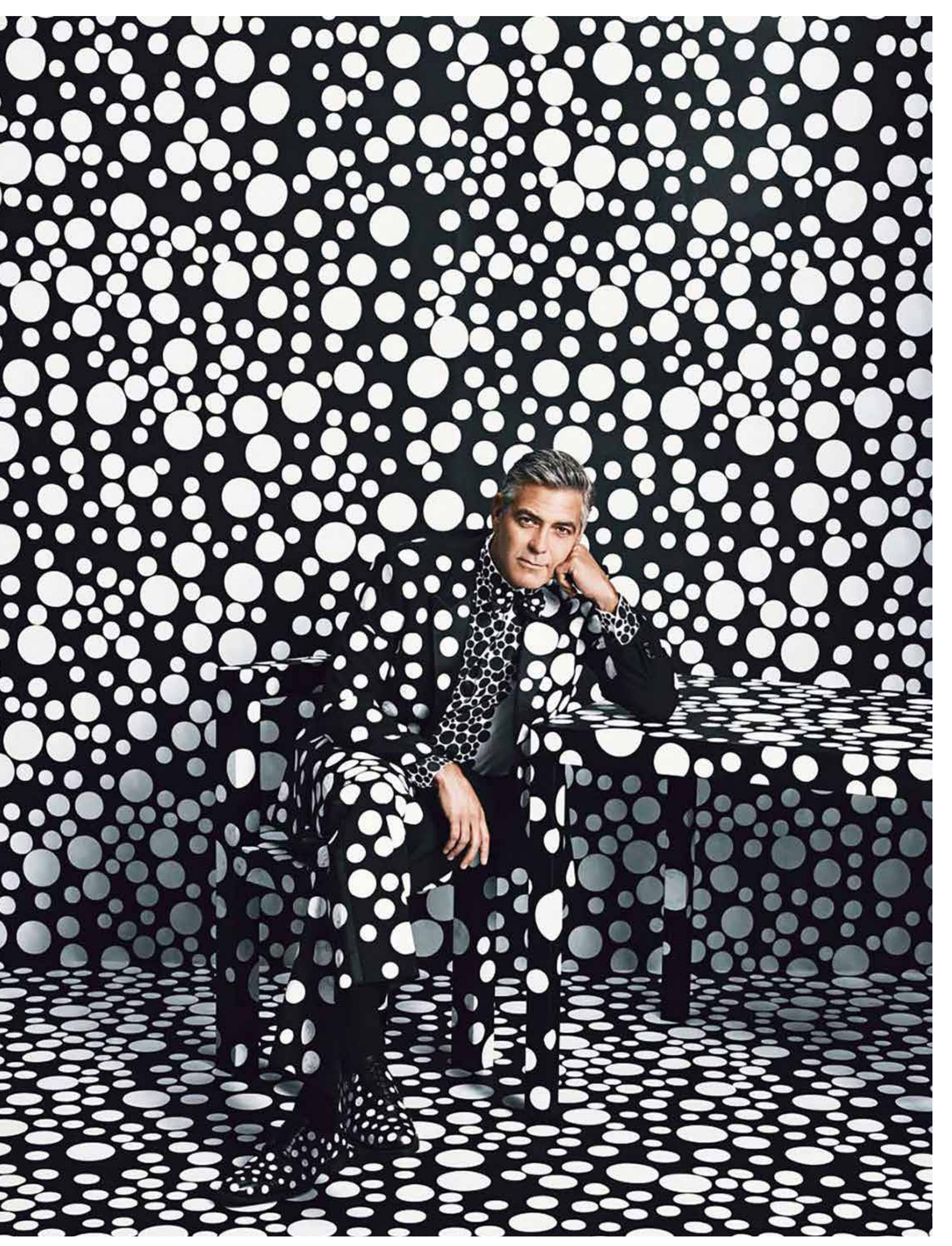

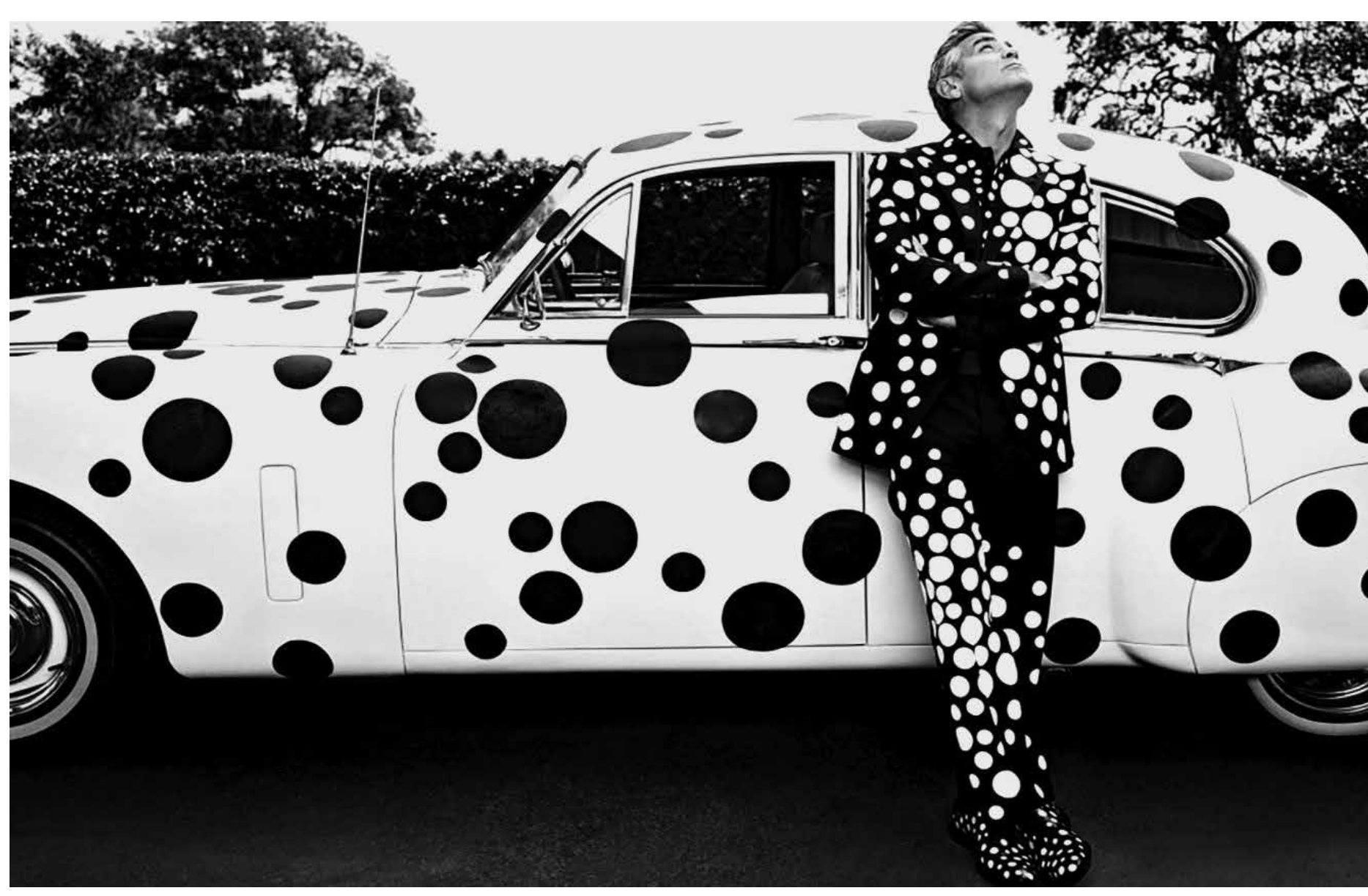

Esse ambiente propõe uma experiência que, de algum Emma Summerton

modo, resgata o tempo da fruição e da imersão estética $\begin{aligned} & \text { George Clooney } \\ & \text { Revista W Magazine, } 2013\end{aligned}$ em um universo em que a pressa e a multidão se colocam de fora. Ao contrário das grandes exposições onde se concorre com o tempo e com as pessoas que buscam se aproximar mesmo que por segundos do original, aqui o "original" se apresenta num ambiente privilegiado, onde o espectador se coloca diante de um objeto renovado, vivendo uma espécie de experiência em que a arte, posta claramente no contexto do consumo, é transformada definitivamente em mercadoria, não uma mercadoria qualquer, mas algo que permite um estado de fruição que só a arte permitiria. Os desdobramentos das ações de comunicação podem ser vistos no editorial da revista W de dezembro de 2013. Nela, a fotógrafa Emma Summerton publica um ensaio com o ator George Clooney com vestimenta e objetos com estampas
Ensaio fotográfico publicado na sequência do lançamento da coleção Infinity Kusama donev-emma-summerton-w-magazinedecember-january-2013/
A cesso em 26 de dezembro de 2017 

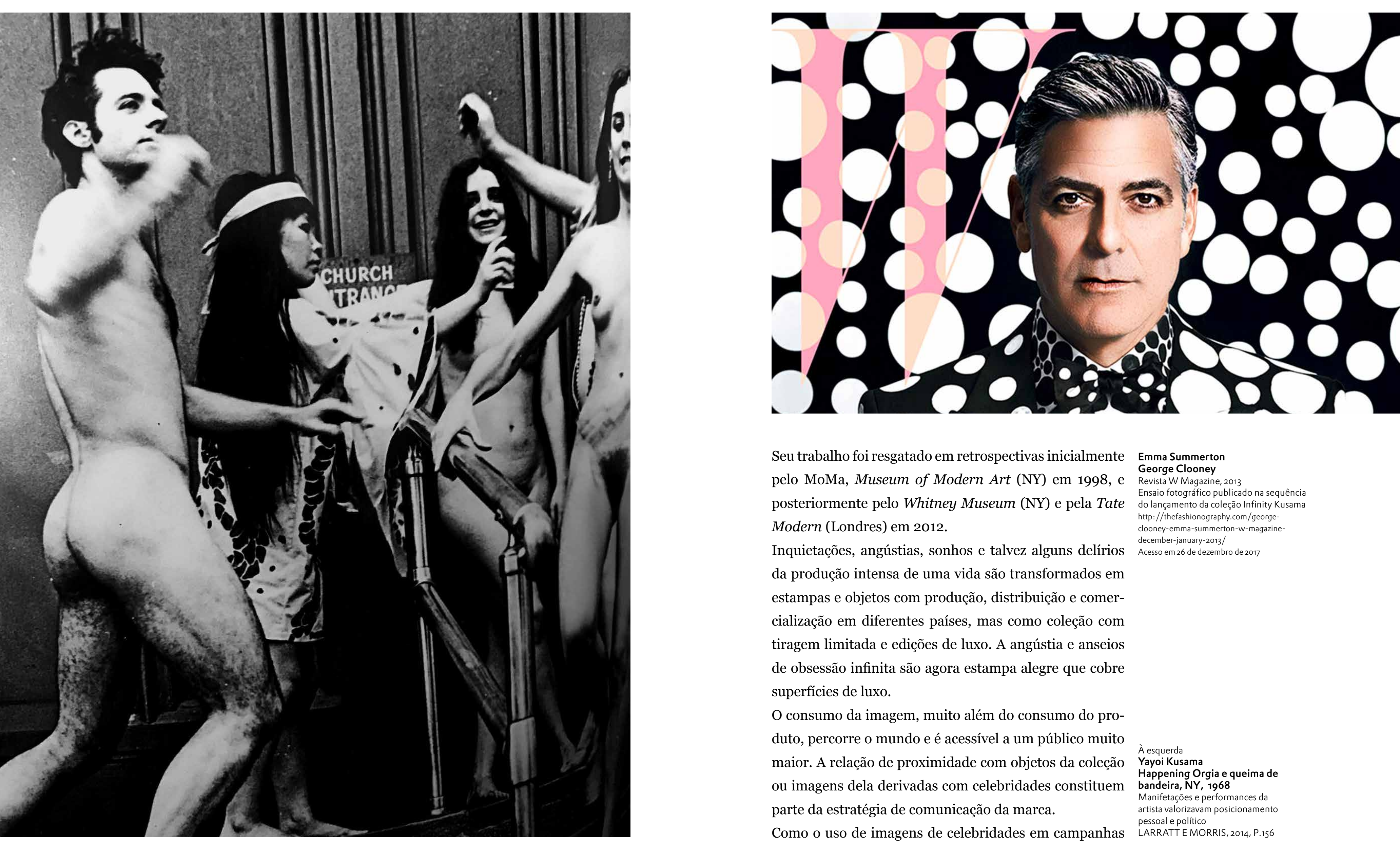

Seu trabalho foi resgatado em retrospectivas inicialmente Emma Summerton pelo MoMa, Museum of Modern Art (NY) em 1998, e posteriormente pelo Whitney Museum (NY) e pela Tate Modern (Londres) em 2012.

Inquietações, angústias, sonhos e talvez alguns delírios da produção intensa de uma vida são transformados em estampas e objetos com produção, distribuição e comercialização em diferentes países, mas como coleção com tiragem limitada e edições de luxo. A angústia e anseios de obsessão infinita são agora estampa alegre que cobre superfícies de luxo.

O consumo da imagem, muito além do consumo do produto, percorre o mundo e é acessível a um público muito maior. A relação de proximidade com objetos da coleção ou imagens dela derivadas com celebridades constituem parte da estratégia de comunicação da marca. Revista W Magazine, 2 Ensaio fotográfico publicado na sequência Io $/$ /thefschiona coleçáo Infinity Kusona clooney-emma-summerton-w-magazinedecember-january-2013/ $/$-magaz
Acesso em 26 de dezembro de 2017

Como o uso de imagens de celebridades em campanhas

À esquerda A bandeira, NY, 1968 Manifetações e performances da artista valorizavam posicionamento pessoal e político
LARRATT E MORRIS, 2014, P.156 


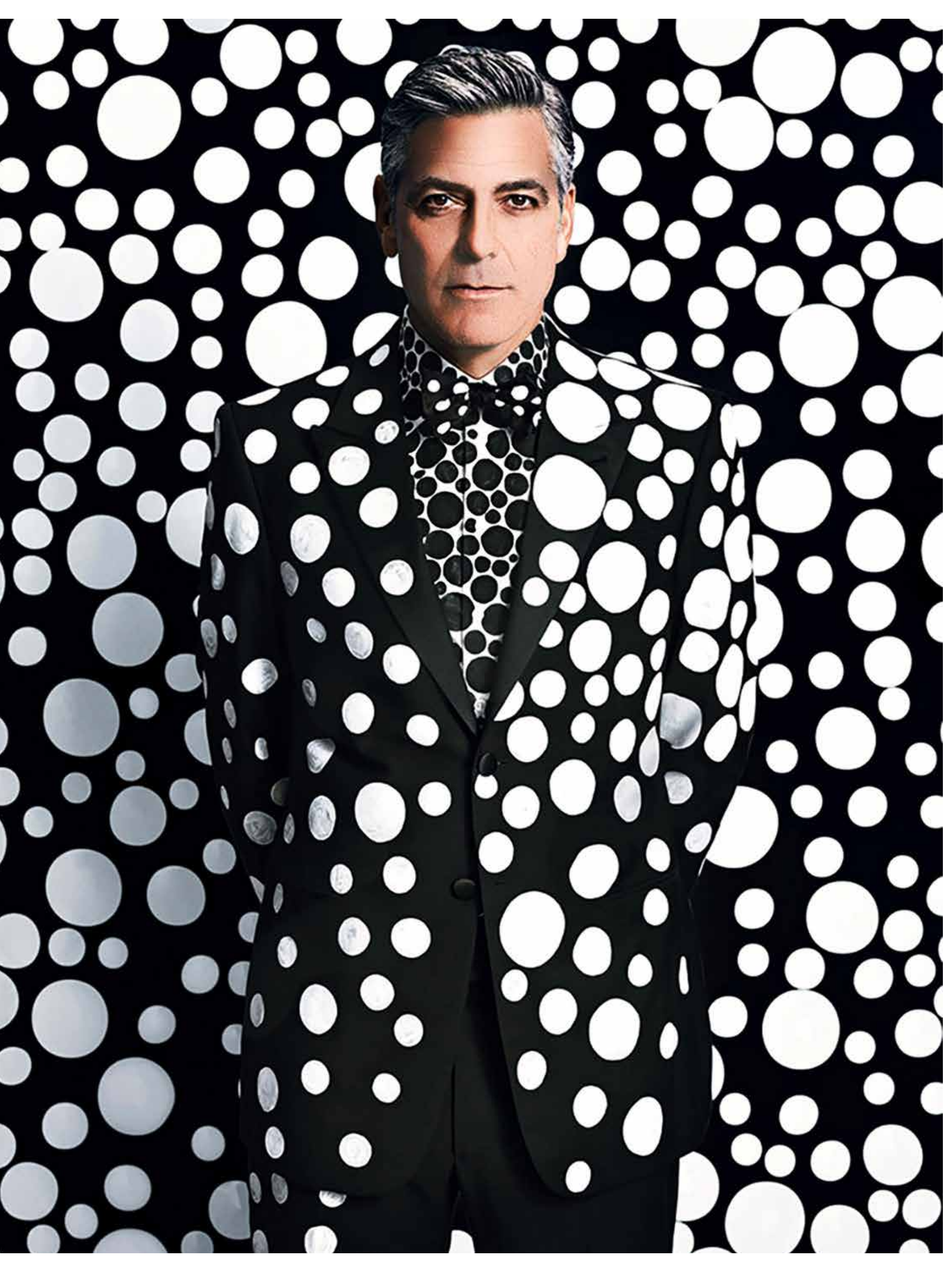

publicitárias e editoriais de moda influenciam o público? Que efeito se busca ao trazer para a cena essas celebridades? O trabalho da artista não é suficiente? Percebe-se uma mistura entre obra, artista, celebridade, visibilidade. As relações entre a obra pública e a vida privada do artista quebram-se a favor de que qualquer acontecimento vire notícia e, assim, possa construir para o produto a credibilidade emprestada do ser criativo.

No trabalho da fotógrafa Emma Summerton, o padrão de círculos, desdobramento de Infinity Kusama, provoca uma sensação de mimetismo entre figura e fundo. A imagem do ator George Clooney, vestido e cercado pelo padrão, mistura-se à imagem da campanha e da coleção. Esta imagem do Clooney, nos remete ainda à outra de Kusama, imersa em sua obra. A diferença é que ela, em meio a falos e tentáculos, integra-se à obra, transforma-se e faz parte dela. Ele, ao contrário, parece assumir um Emma Summerton disfarce e, como um camaleão, quase desaparece. Como um jogo que se constrói entre a afirmação da presença célebre e o seu quase desaparecimento. Entre o entrever e reconhecer a celebridade, como uma descoberta reservada a poucos eleitos 


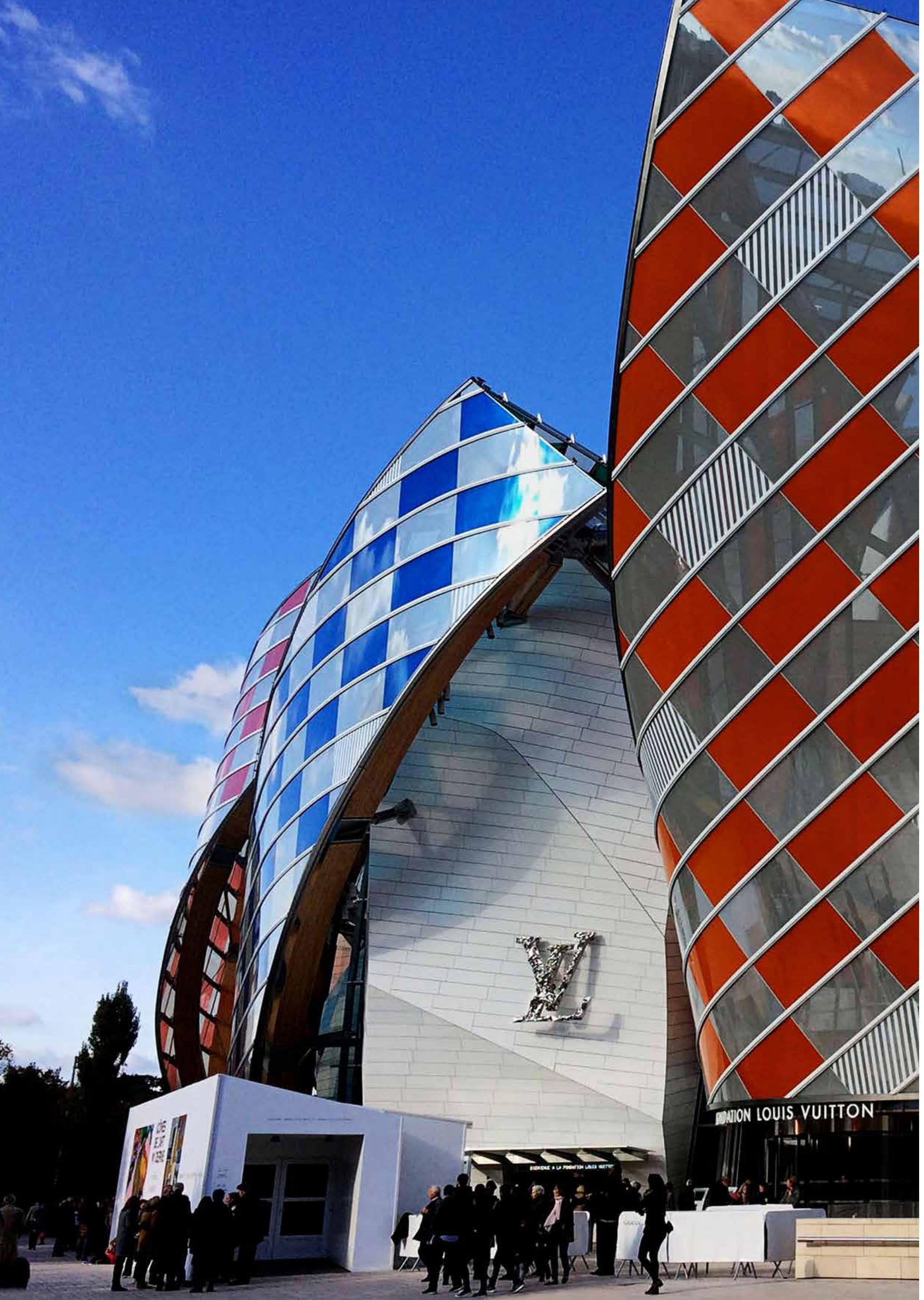

\section{Design mercadoria}

Marca, consumo e luxo

Atender a um briefing para o mercado premium é desafio Fondation Louis Vuitton comun para o designer. A categoria premium geralmente agrega produtos e matéria-prima de melhor qualidade e, certamente por isso, recebe maior investimento para Projeto de Frank Gehry Daniel Buren L'Observatoire de la lumière Obra in situ, 2016
Foto do autor, 2016 desenvolvimento e produção. Isto se aplica para os diferentes setores em que a hierarquia e famílias de produtos se distribuem, como os alimentícios e os de higiene pessoal. Por exemplo, marcas e produtos que muitas vezes, embora posicionem-se no mercado como concorrentes, pertencem as mesmas e grandes corporações.

Na indústria de móveis, a escolha dos materiais e processos também determina o público alvo, enquanto na automobilística, a definição do público é mais complexa, passando da potência do motor, materiais, tecnologias de fabricação e a marca. No mercado da moda e acessórios, 

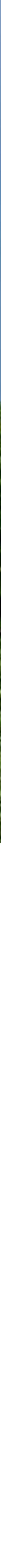

talvez persistam esses elementos, mas ainda recebem Fondation Louis Vuitton outras formas de atribuição de valor. Sem dúvida, para muito além da função básica do vestuário de proteger das intempéries, a moda transita por caminhos ainda mais Paris, FR, 2013 Foto da edificação: http://www. complexos e constrói identidades individuais e de grupos. Um mercado restrito com alto valor imaterial movimenta uma indústria com abrangência global. Além da qualidade de artesania e manufatura, os produtos desenvolvidos para marcas que se posicionam para atender o mercado de luxo são constituídos de outra matéria, menos tangível e não menos presente.

Ao tomar como referência a Louis Vuitton, pode-se afirmar que as estratégias utilizadas para comunicação e construção desta marca se aplicariam a muitas outras, tais como Prada, Gucci, Armani, Cartier, que atuam nos mesmos segmentos. 


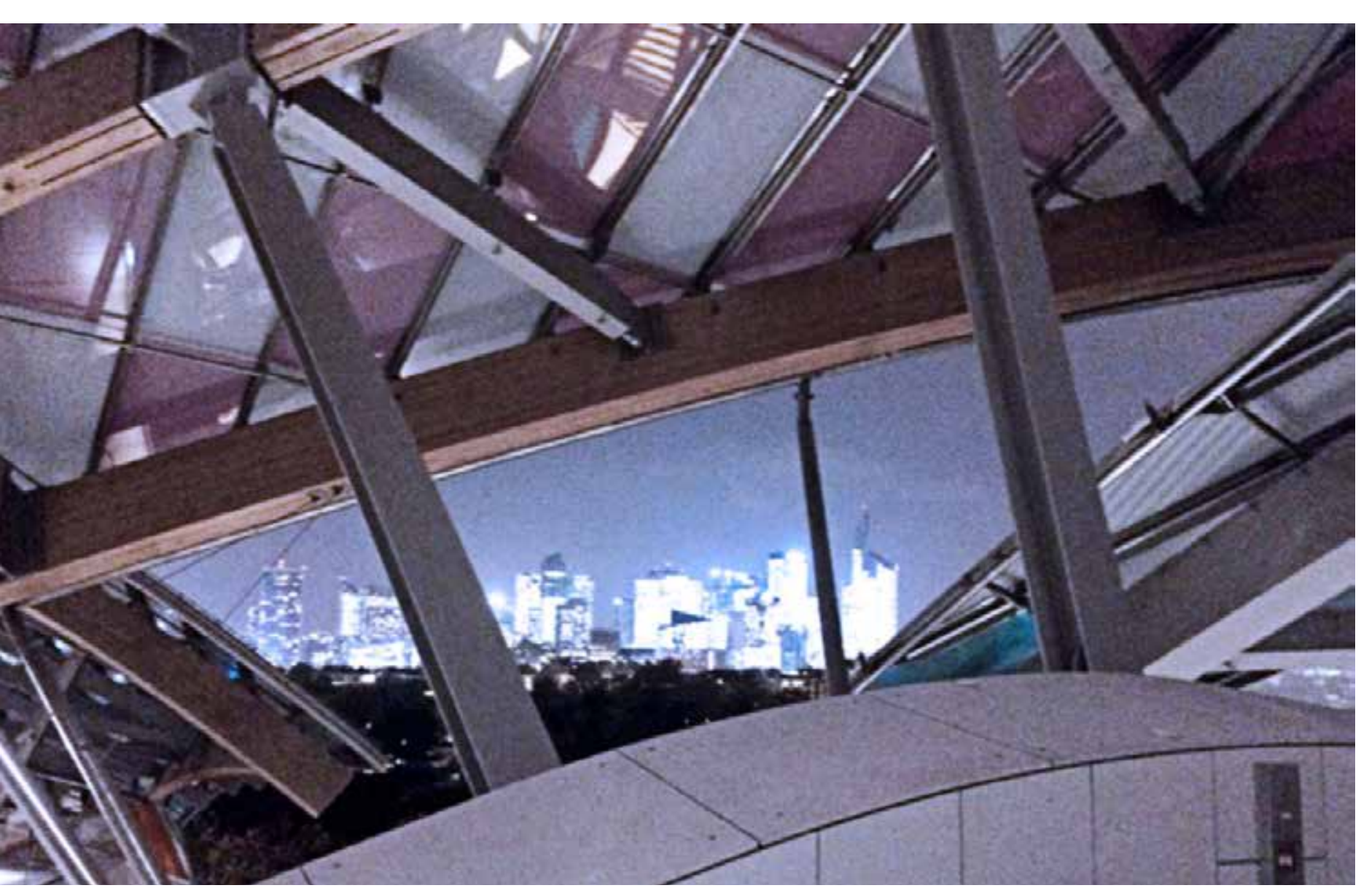

Fondation Louis Vuitton A criação de uma fundação cultural, segundo informações Projeto de Frank Gehry
Vista interna das estruturas de sua página oficial, estabelece nova etapa para o meceParis, FR, 2013

Fotos do autor, 2016

nato do grupo LVMH, detentor desta e de várias outras marcas para o mercado premium, tais como: Fendi, Bvlgari, Donna Karan, Emilio Pucci, Givenchy, Kenzo, Marc Jacobs, Sephora, Le Bon Marché. Após 25 anos de investimentos de patrocínio para a arte, a cultura e patrimônio, Bernard Arnault, presidente do grupo convida o arquiteto Frank Gehry a projetar um edifício próximo ao centro de Paris para sediar La Fondation Louis Vuitton.

La Fondation Louis Vuitton marque une nouvelle étape dans le mécénat du groupe $L V M H$ et de ses maisons et une cristallisation des actions engagées par elles depuis près de vingt-cing ans pour soutenir l'art, la culture et le patrimoine. Cinq ans après avoir rencontré l'architecte Frank Gehry, Bernard Arnault Président du groupe LVMH, lance un projet d'envergure porté par une ambition renouvelée : Un engagement de pérennité avec la volonté de s'enraciner dans un lieu et faire vivre une institution dans la durée. http://www.fondationlouisvuitton.f

A Fundação Louis Vuitton marca uma nova etapa no patrocínio do Grupo LVMH e suas casas, e uma cristalização das ações que realizaram há quase vinte e cinco anos para apoiar arte, cultura e patrimônio. Cinco anos depois de conhecer o arquiteto Frank Gehry, Bernard Arnault, presidente do grupo LVMH, lança um grande projeto impulsionado por uma ambição renovada: Um compromisso com a sustentabilidade, com o desejo de enraizar-se em um lugar e sustentar uma instituição ao longo do tempo. Tradução livre

Historicamente advinda de produção cuidadosa e artesanal voltada para objetos de viagem e selaria, a marca Louis Vuitton estrutura-se hoje para o desenvolvimento de produtos e utiliza-se de estratégia de aproximação com grandes nomes do design, da arte, da aquitetura, da fotografia e do cinema.

Un acte philanthropique majeur vis-à-vis de Paris avec la construction d'un bâtiment exceptionnel sur le domaine public municipal et la signature avec la Ville de Paris d'une convention d'occupation de 55 ans. Initiative culturelle privée, la Fondation Louis Vuitton est née d'une volonté partagée et se veut partie prenante d'un territoire. Ancrée au cœur du Grand Paris, dans le Bois de Boulogne, à la frontière des villes de Paris et de Neuilly-sur-Seine, elle entend s'inscrire dans le paysage culturel francilien et renouveler l'intérêt pour l'Ouest parisien.

Animée par une mission d'intérêt général, la Fondation Louis Vuitton affiche un engagement affirmé en faveur de 


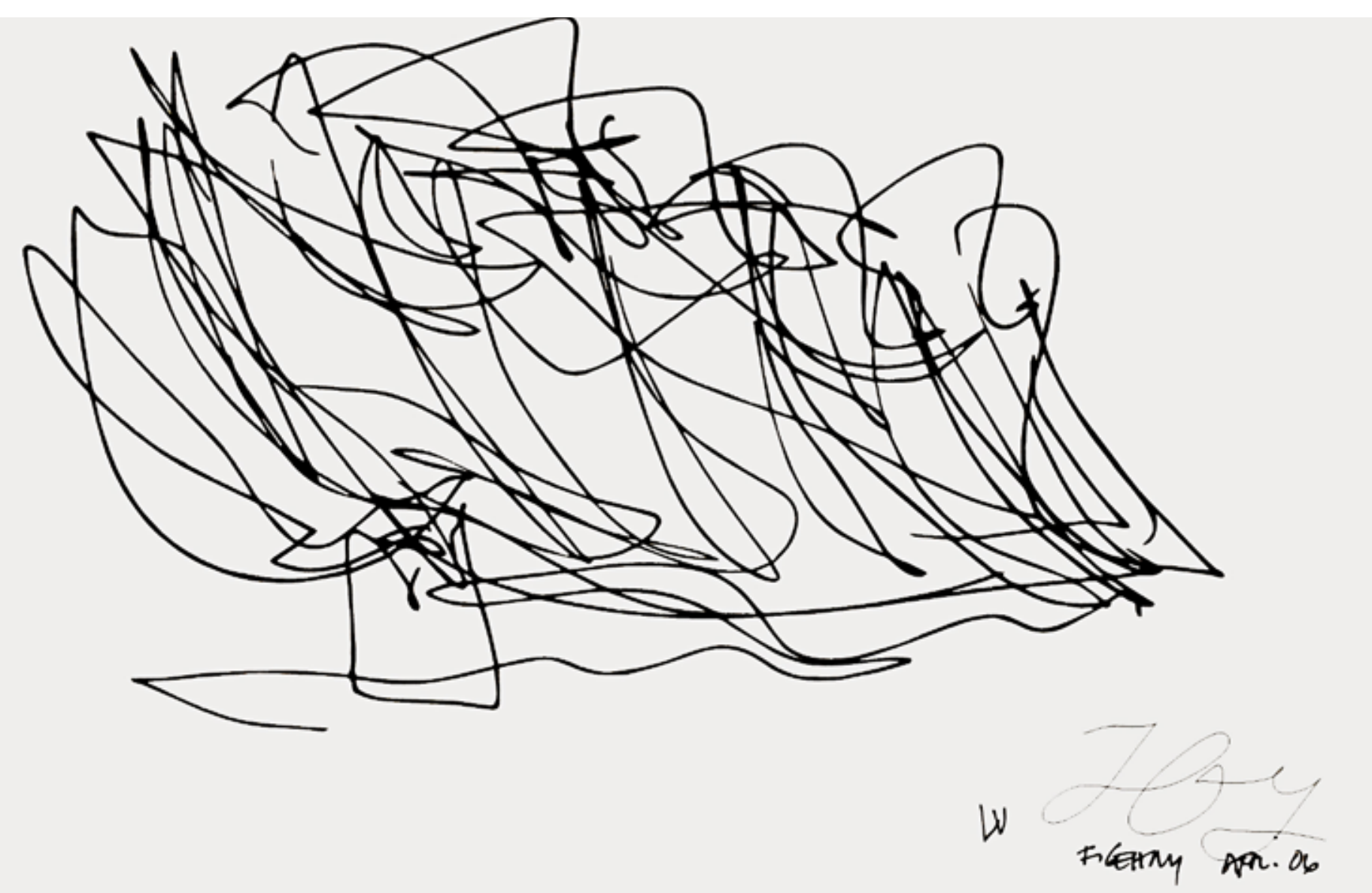

"Un espace nouveau qui l'art contemporain et souhaite le rendre accessible au plus ouvre le dialogue avec un grand nombre. Pour promouvoir la création artistique conlarge public et offre aux temporaine sur le plan national et international, la Fondaartistes et aux intellectuels tion Louis Vuitton s'appuie sur une collection permanente, une plateforme de débats des commandes d'artistes, des expositions temporaires et de réflexion." d'art moderne et contemporain et des manifestations pluridisciplinaires. Elle compte parmi ses priorités la mise en "Um novo espaço que abre o œuvre d'une mission pédagogique, notamment auprès des diálogo com um público am- jeunes publics. Promouvoir la création du temps présent en afplo e oferece aos artistas e firmant un parti pris d'ouverture et de dialogue avec les artisintelectuais uma plataforma tes, les intellectuels et le public. - Emouvoir et surprendre les

de debate e reflexão". publics en exposant le travail des créateurs dans un bâtiment

Bernard Arnault innovant, fleuron d'une architecture emblématique signée Frank Gehry.

[http://www.fondationlouisvuitton.fr/ Acesso em 28 de dezembro de 2017]

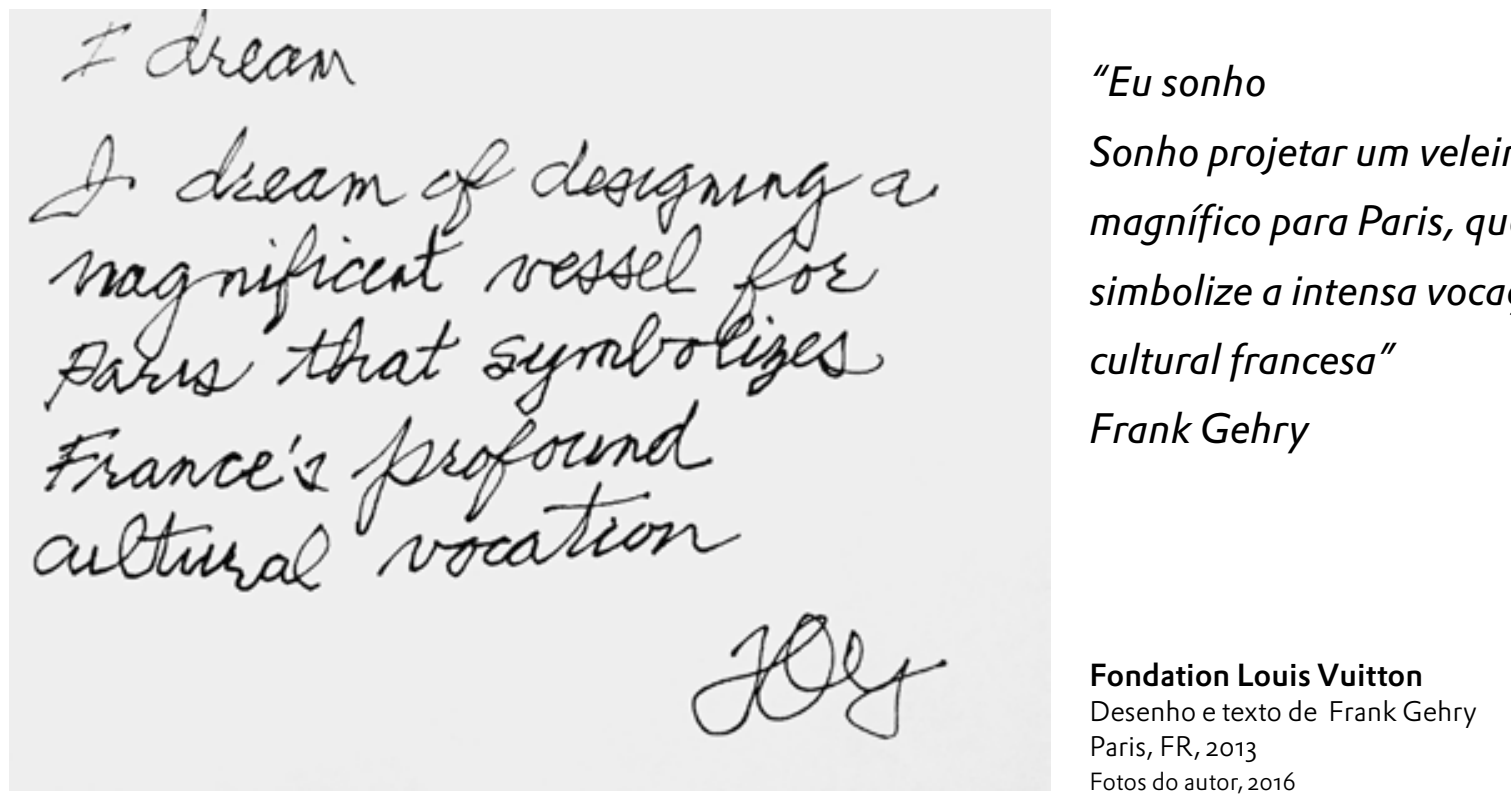

Um importante ato filantrópico em relação a Paris com a construção de um edifício excepcional no domínio público municipal e a assinatura com a cidade de Paris de um contrato de ocupação de 55 anos. Uma iniciativa cultural privada, a Fundação Louis Vuitton nasceu de uma vontade compartilhada e quer se tornar parte de um território. Ancorado no coração da Grande Paris, no Bois de Boulogne, na fronteira das cidades de Paris e Neuilly-sur-Seine, pretende se juntar à paisagem cultural da região parisiense e renovar o interesse na região Oeste de Paris. Impulsionada por uma missão de interesse geral, a Fundação Louis Vuitton tem um forte compromisso com a arte contemporânea e quer torná-la acessível para o maior número possível de pessoas. Para promover a criação artística contemporânea a nível nacional e internacional, a Fundação Louis Vuitton conta com uma 


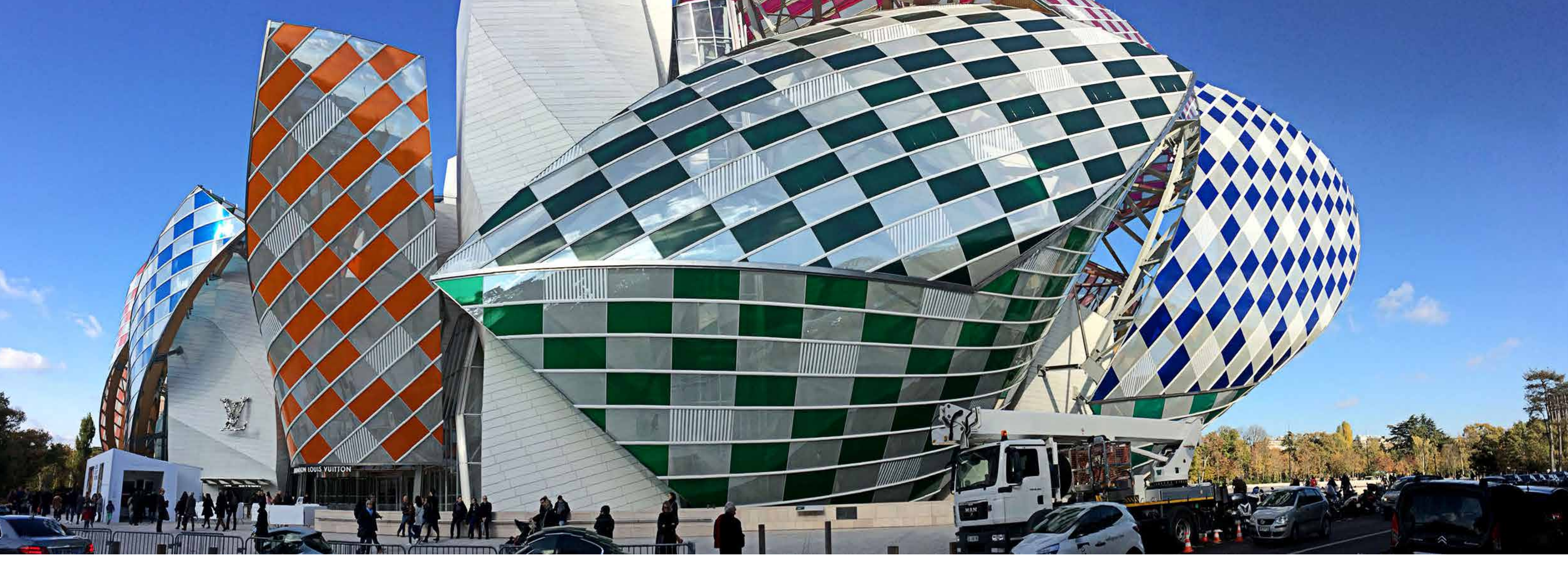

coleção permanente, comissões de artistas, exposições temporárias de arte moderna e contemporânea e eventos multidisciplinares. Entre as suas prioridades está a implementação de uma missão pedagógica, particularmente para o público jovem.

Promover a criação do tempo presente, afirmando uma tendência de abertura e diálogo com artistas, intelectuais e público. Para excitar e surpreender o público, expondo o trabalho dos criadores em um edifício inovador, emblemático de uma arquitetura emblemática assinada por Frank Gehry.”

Tradução livre
A ideia de mecenato, por si só antecipa um pensamento de produção cultural com suporte financeiro do grupo. A aproximação entre marca, produtos e a produção cultural com abrangência global traz um status que contribui com a percepção de objetos de valor por ela produzidos e distribuídos. À sensação de exclusividade, ao serviço de atendimento personalizado, à matéria prima utilizada somam-se a tiragem limitada, o princípio de coleção, aos pontos de distribuição em endereços sofisticados. Mas vai além disso. Um objeto produzido por uma maison que também investe em arte e cultura, recebe um status que o diferencia dos demais. Uma certa contaminação de qualidades estéticas que suplanta a materialidade do objeto e, sem dúvida, as funções objetivas para o qual fora desenvolvido. O design deluxo e para o luxo tem, teoricamente, o melhor material, a melhor estrutura de produção, o melhor contexto de exposição, distribuição e comercialização.
Fondation Louis Vuitton Projeto de Frank Gehry Paris, $\mathrm{FR}, 2013$ L'Observatoire de la lumière Foto do autor, 2016 



Embora produzidos em série, nem sempre comprovadamente em boas condições para os operários, os objetos ganham essa aura de objeto único. Possuir um objeto desta categoria de produtos confere ao seu portador a qualidade de ser cult para o contexto em que circula. Essa espécie de contaminação do design por procedimentos normalmente atribuidos as artes visuais - tiragem, material, técnica, estilo - também ganha espaço quando associada a outras manifestações artísticas tais como música, dança, teatro, dentre outras.

O financiamento de shows e grupos fortelece a percepção de que a marca proporciona a seu público a possibilidade de viver experiências que tocam seus sentidos e que pode criar momentos memoráveis.

Estar na memória, associado a bons momentos estabelece também o sentimento de pertencer a um grupo especial, restrito, exclusivo. 

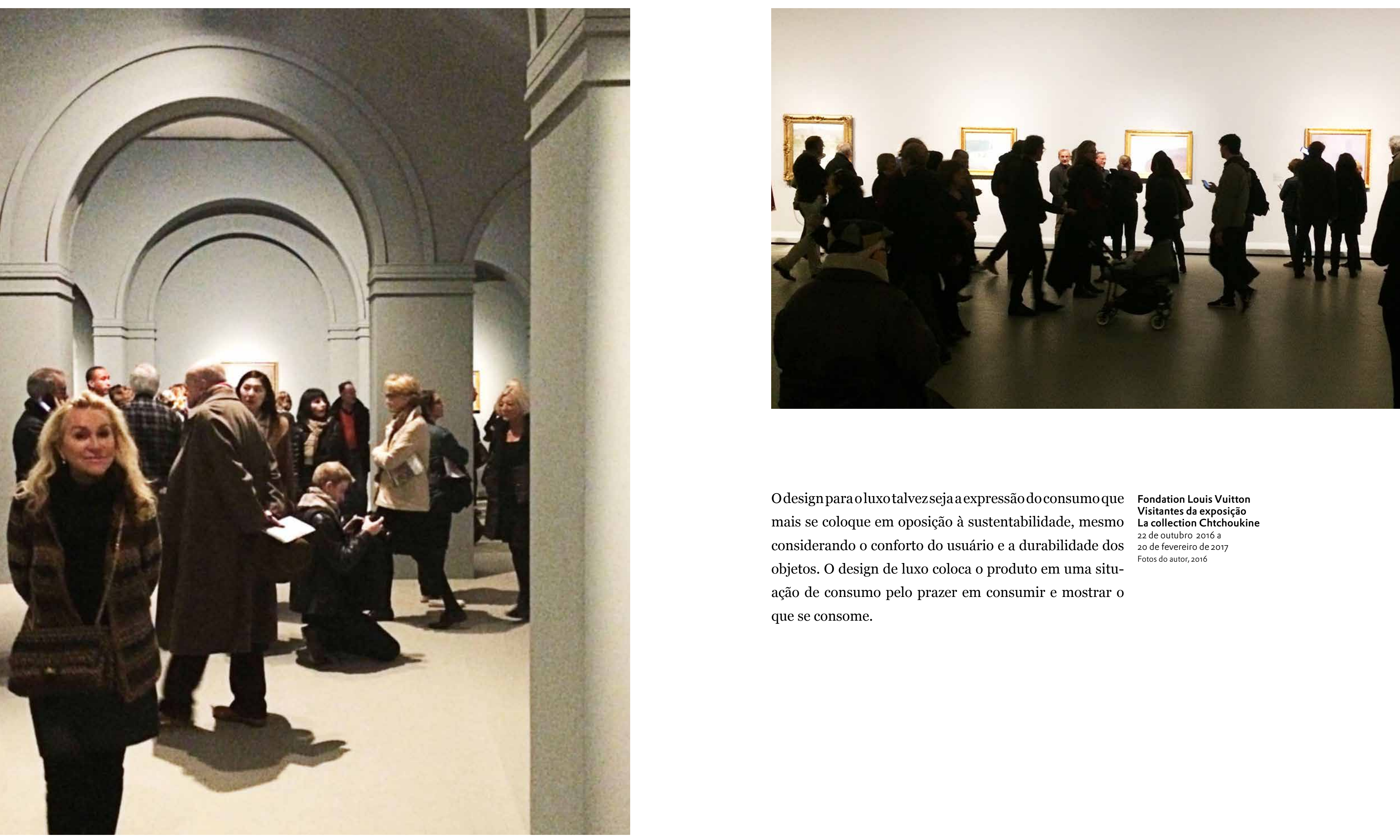

Odesign para oluxotalvez seja a expressão doconsumoque Fondation Louis Vuitton mais se coloque em oposição à sustentabilidade, mesmo Va collection Chtchoukine considerando o conforto do usuário e a durabilidade dos $\begin{aligned} & 22 \text { de outubro } 2016 \text { a a } \\ & 20 \text { devereiro de } 2017\end{aligned}$ objetos. O design de luxo coloca o produto em uma situação de consumo pelo prazer em consumir e mostrar o que se consome. 


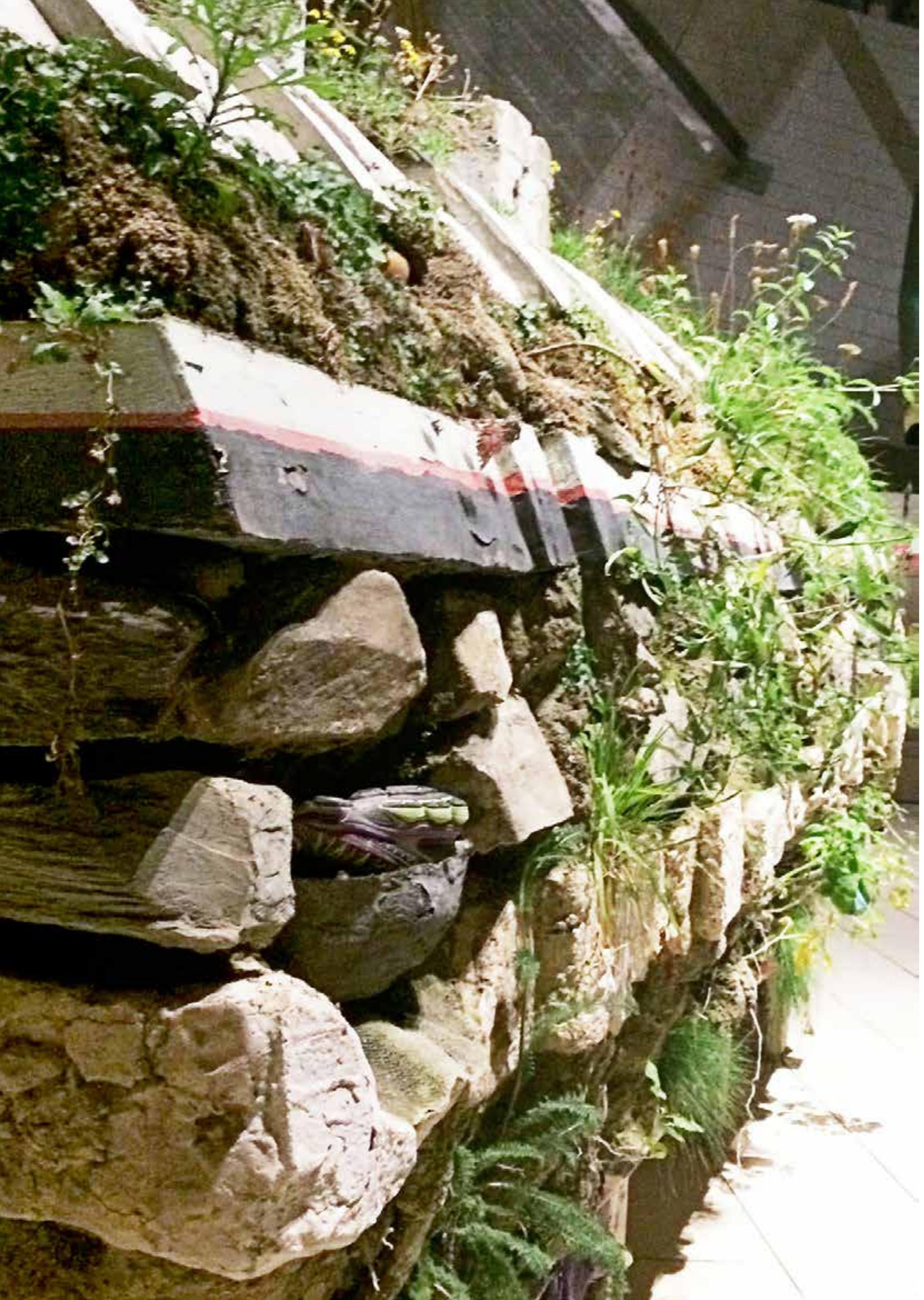

\section{Curadoria \\ Design e outras produções culturais}

A Fondation Louis Vuitton é uma manifestação concreta Adrián Villar Rojas do investimento da marca em produção cultural. Situada Arte contemporânea em exposiçã̃o dentro de um espaço público, o Jardin d'Acclimatation, Fotodoautor Bois de Boulogne, Rue du Bois de Boulogne, 75116 Paris, França, ocupa uma área de 11.000 metros quadrados.

O fato de receber concessão pública para a construção de um centro cultural em área importante parece reflexo da importância do grupo LVMH na economia francesa. A escolha do arquiteto Frank Gehry para o projeto gerou grande interesse no meio dos arquitetos com atuação global. Reconhecido por projetos que sempre provocaram impacto no entorno de implantação, o arquiteto explica suas decisões conceituais para este projeto: sua inspiração foi um veleiro em movimento. Cada piso da edificação parece suspenso tendo velas transparentes como 


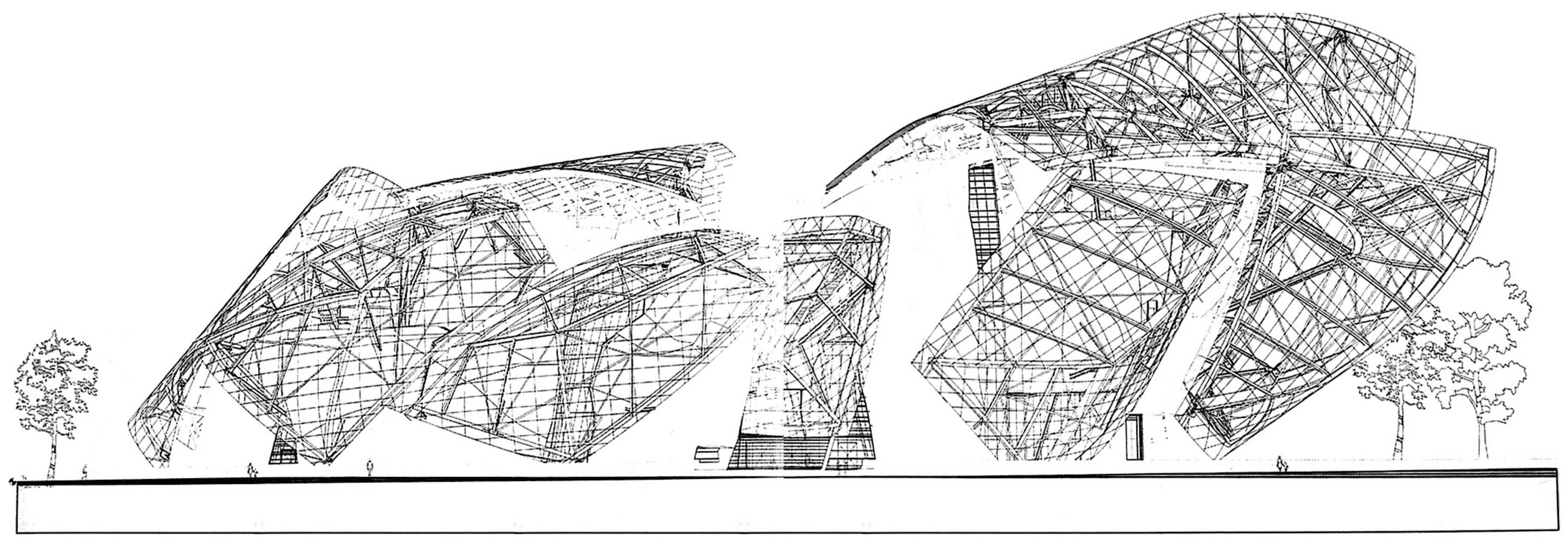

cobertura. Todos os processos de desenvolvimento e de construção, incluindo pesquisas de materiais e métodos, foram registrados e encontram-se em exposição e disponíveis para pesquisadores nas instalações da instituição. A programação do centro cultural se desenvolve a partir de uma mistura de arte tradicional e contemporânea. Seu campo de atuação é composto por uma diversidade de manifestações artísticas incluindo artes visuais, música, performances, dança. Em visita ocorrida em novembro de 2016 se pode ver uma intervenção artística in situ de Daniel Buren, L'Observatoire de la lumière: grandes áreas de cor, conseguidos a partir de adesivos transparentes, criaram um quadriculado sobre a superfície de vidro que reveste todo o edifício. No interior da construção, os adesivos funcionam com os filtros coloridos manchando grandes áreas nos espaços de convivência. A ação curatorial provavelmente leva em conta a

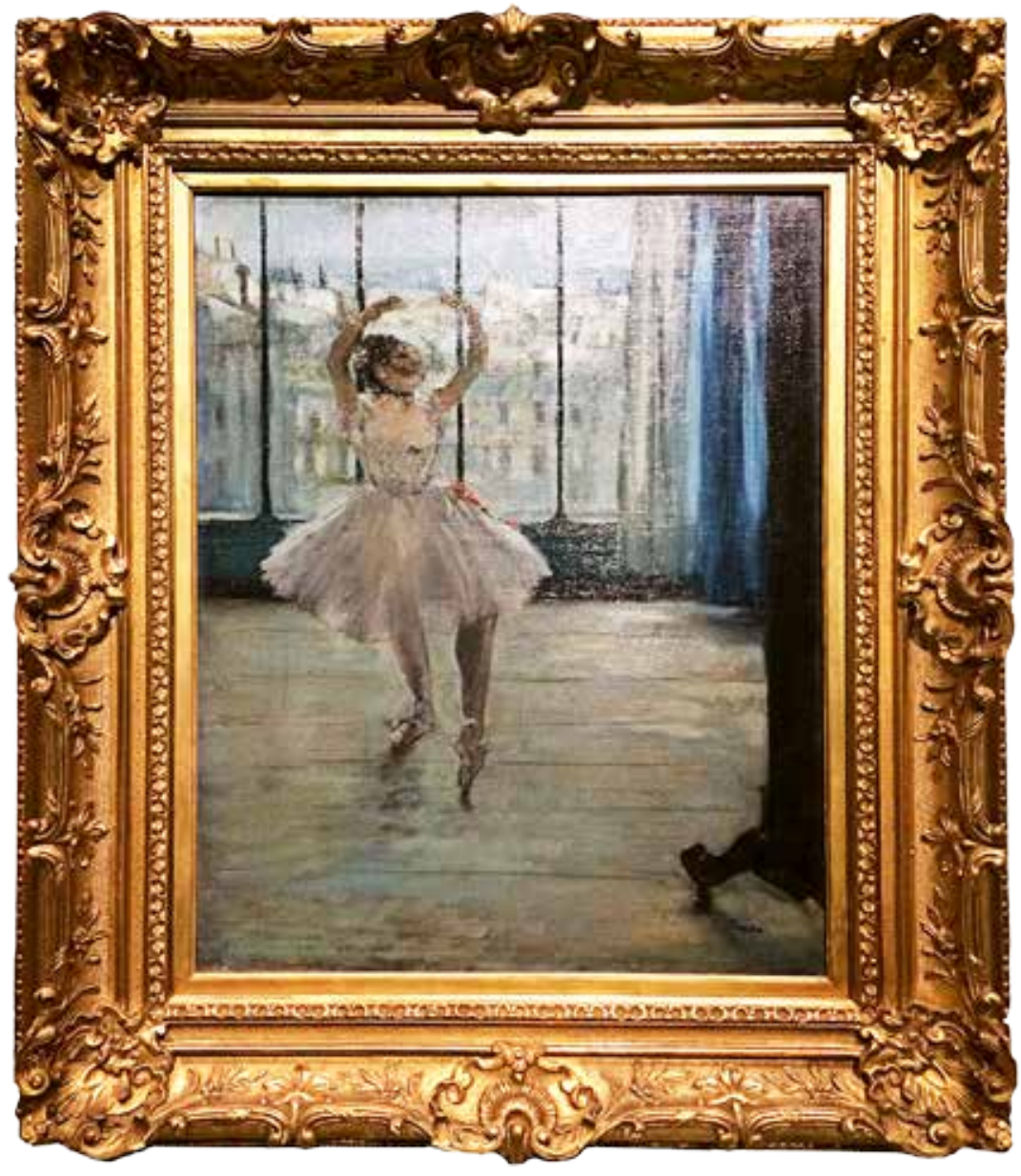

Fondation Louis Vuitton Projeto de Frank Gehry Paris, FR, 2013 Connaissance des arts, special issue, 2015, p.8 e 9

La danseuse dans I'atelier du photographe Edgard Degas, 1875 Coleção Chtchoukine
Fondation Louis Vuitton, 2016 Foto do autor 


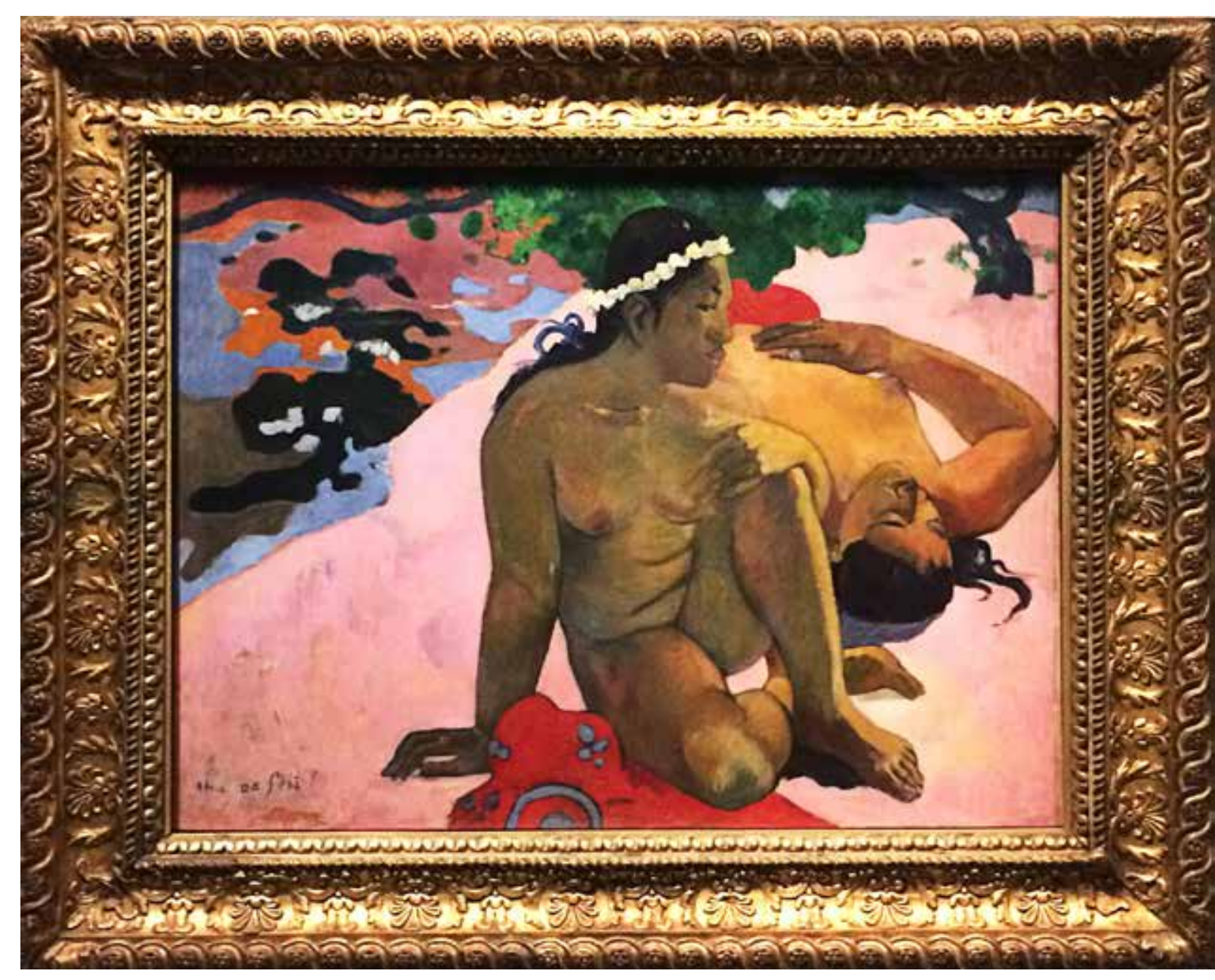

Aha oé feil (Eh quoi, tu es jalouse?) aderência de seu público à produção contemporânea. Gauguin, 1892
Clocão Chtchoukine Dividem os espaços do centro cultural artistas consagraColeção Chtchoukine
Foton do autor
fos, grandes nomes da pintura mundial e novos talentos.

Adrián Villar Rojas A coleção de Chtchoukine, composta por obras de GauWhere the slaves live, 2014
Arte contemporânea em exposição guin, Monet, Cézanne, Picasso, Matisse e Degas ocupou Foto do autor quatorze salas e quatro pisos. Distribuídas de forma didática, as pinturas da coleção que pertence à Galeria Sergei Ivanovich Shchukin de Moscou recontam parte da história da pintura com destaque para o impressionismo e para o modernismo.

Em um dos terraços, pode-se ver uma obra contemporânea do escultor argentino Adrián Villar Rojas. Um grande objeto composto por sobreposição de materiais: concreto, areia, pedras, pigmentos, terra, plantas de diferentes espécies. Uma escultura viva, chamada Where the slaves live, realizada em 2014.

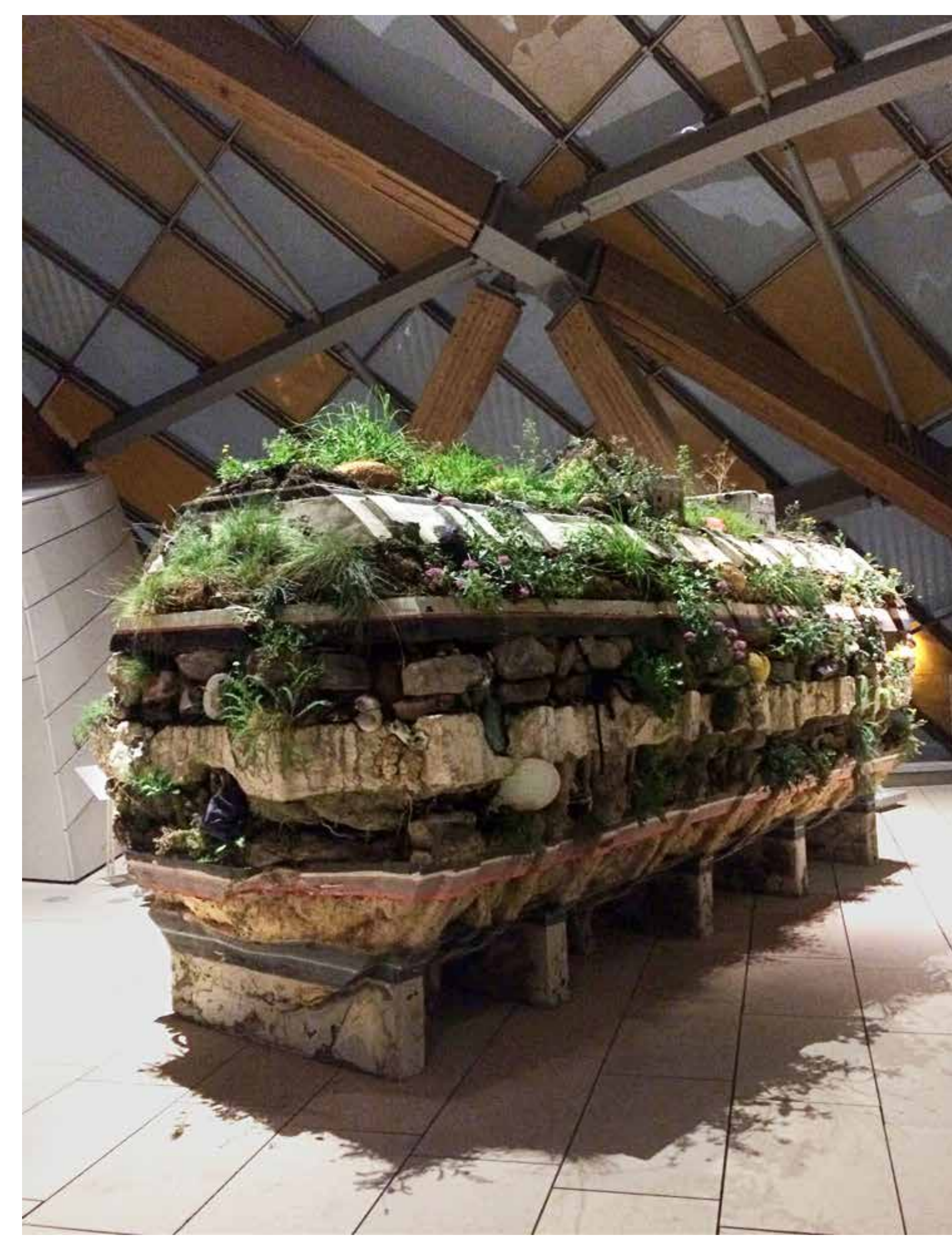




\section{Gucci \\ Estratégias de reposicionamento}

A italiana Gucci, também do mercado de luxo, tem desenvolvido estratégias para atualizar seu estilo e captar um público mais jovem a partir da contratação de Tom Ford em 1999. Fundada por Guccio Gucci (18811953) em Florença em 1921, hoje pertence à holding franAdrian Kozakiewicz (a) histórias narradas no site da marca Gucci https://www.gucci.com/us/en/st/ stories/visions/article/fall-winter-2017cesa Kering. Como outras grandes, a Casa Gucci começou com a produção de peças de couro, dentro de uma estrutura familiar e quase artesanal. Após um período de crise e ameaça de falência, a direção artística da marca e de todo o grupo Yves Saint Laurent foi entregue a Tom Ford - que lhe atribuiu um novo estilo - jovem, ousado e sofisticado, na busca de afirmação global. A Casa Gucci, com novo diretor criativo, Alessandro Michele, 42 anos, gerou US\$ 4,7 bilhões das receitas mundiais do grupo em 2015 desde que assumiu no início deste mesmo ano. 

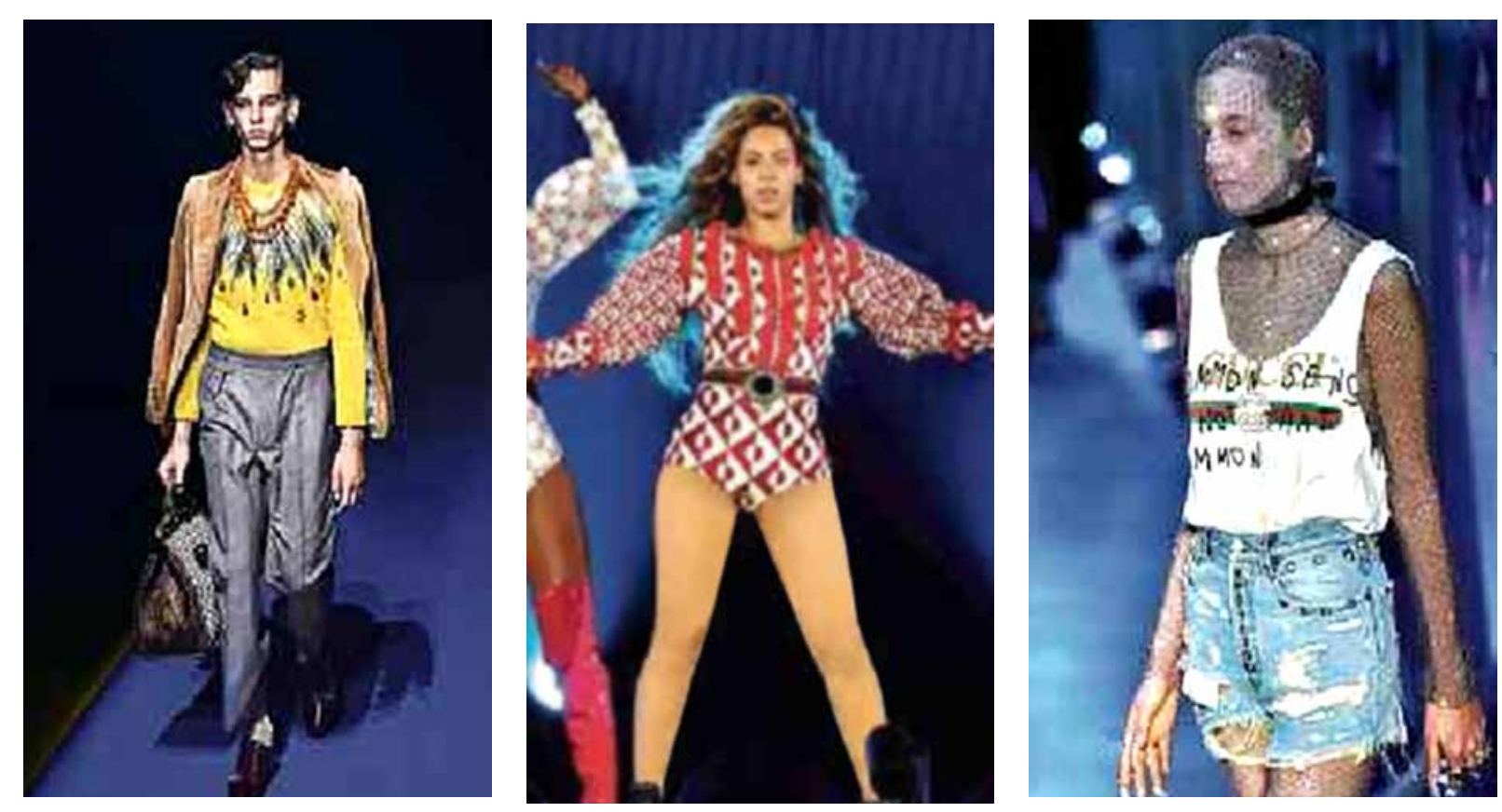

\section{Sem gênero}

Primeira grife de luxo a acabar com a divisão entre

as coleções masculina e feminina. $O$ estilo segue o mesmo padrão com poucas diferenças entre a roupa de homem e mulheres.
Pop millennial Parceria com a Beyoncé em sua turnê e clipe da música Formation aproximou a mardo público jovem, que não tinha empatia com a grife estagnada pelos millennials. considerada velha
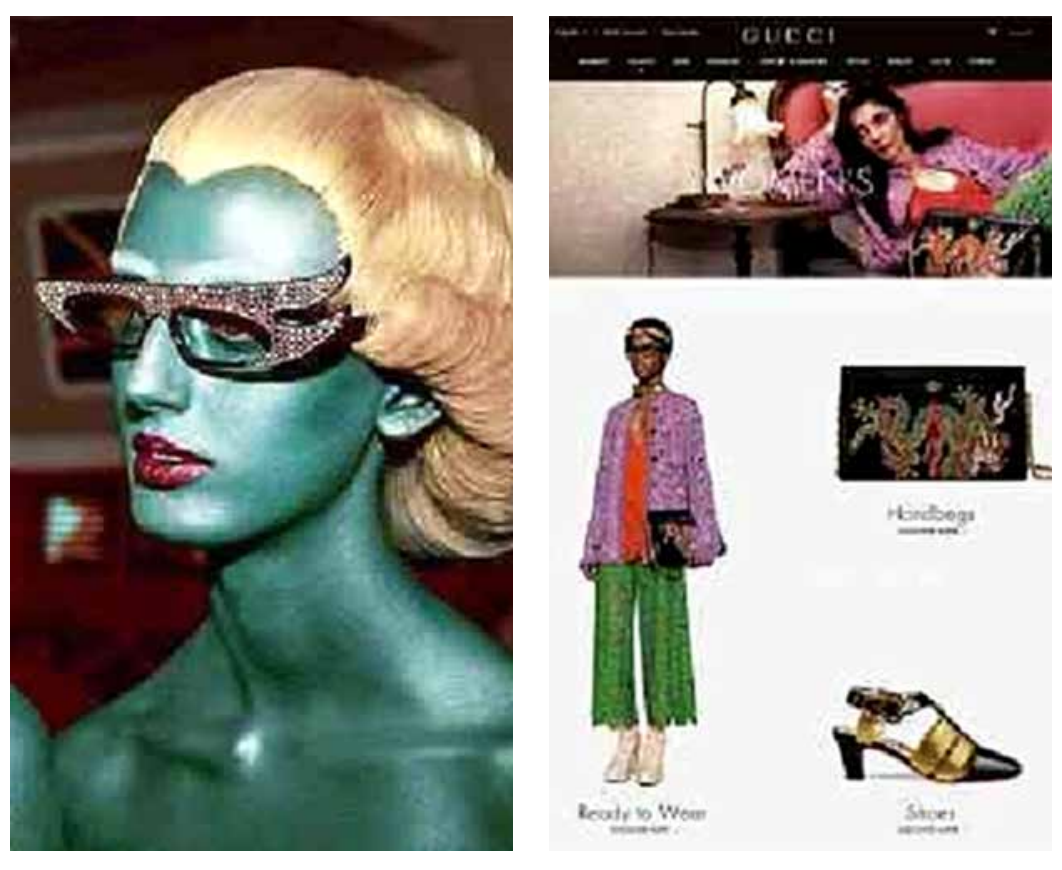

$\sin =$

\begin{tabular}{|c|c|c|}
\hline Campanhas nonsense & & $\begin{array}{l}\text { Pedro Diniz } \\
\text { Folha de São Paulo, } 28 \text { de outubro de } 2017\end{array}$ \\
\hline A publicidade da marca não & E-commerce britânico & 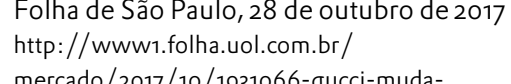 \\
\hline é concentrada em produtos, & Forfethch para entregar pro- & $\begin{array}{l}\text { formula-lidera-vvanco-do-luxo-e-cresce- } 46- \\
\text { em-2017.shtml }\end{array}$ \\
\hline mas em histórias mirabolan- & dutos em 90 minutos em São & Acesso em 28 de outubro de 2017 \\
\hline tes. Na última campanha fo- & Paulo. A plataforma digital é & \\
\hline ram criadas cenas de invasão & integrada às histórias criadas & \\
\hline extra-terrestre e criaturas & a cada coleção, com filmes e & \\
\hline verdes brilhantes. & conteúdo exclusivos. & \\
\hline
\end{tabular}

Em matéria publicada no jornal Folha de São Paulo, em 28 de outubro de 2017, o jornalista especialista em moda Pedro Diniz destaca o salto no faturamento da Gucci com crescimento em $46 \%$, em comparação ao desempenho das outras empresas de luxo, no mesmo período, cujo crescimento foi de $2 \%$. Marco Bizzarri, presidente da marca, defende a agilidade de criação, enquanto o jornalista destaca cinco estratégias para o reposicionamento da marca, reforçadas pelas ações de Michele. 


\section{Sem gênero}

Ideologia de gênero e consumo

A não diferenciação para os gêneros masculino e feminino na modelagem e no estilo amplia o público e alinha-se à crescente discussão a respeito da diversidade e às diferentes questões sociológicas e políticas da corporeidade. Moschino

sido tema de editoriats de moda com bastante frequência, mas o apelo de venda e como parte de estrarentes questóes sociológicas e politicas da corporeidade. tégias de comunicação é mais recente.

tico de posicionamento e resistência, que se coloca em defesa de minorias e busca desestruturar os padrões de forma e de aceitação.

Ao posicionar-se colocando no mercado produtos que não priorizam o gênero, a Gucci busca construir para si uma imagem que a coloca como defensora de causas sociais contemporâneas. Embora o clamor por retirar as diferenças e respeitar as escolhas, independente de gênero, esteja nas ruas e reflita o comportamento do jovem contemporâneo, por associação, a marca se beneficia mesmo 


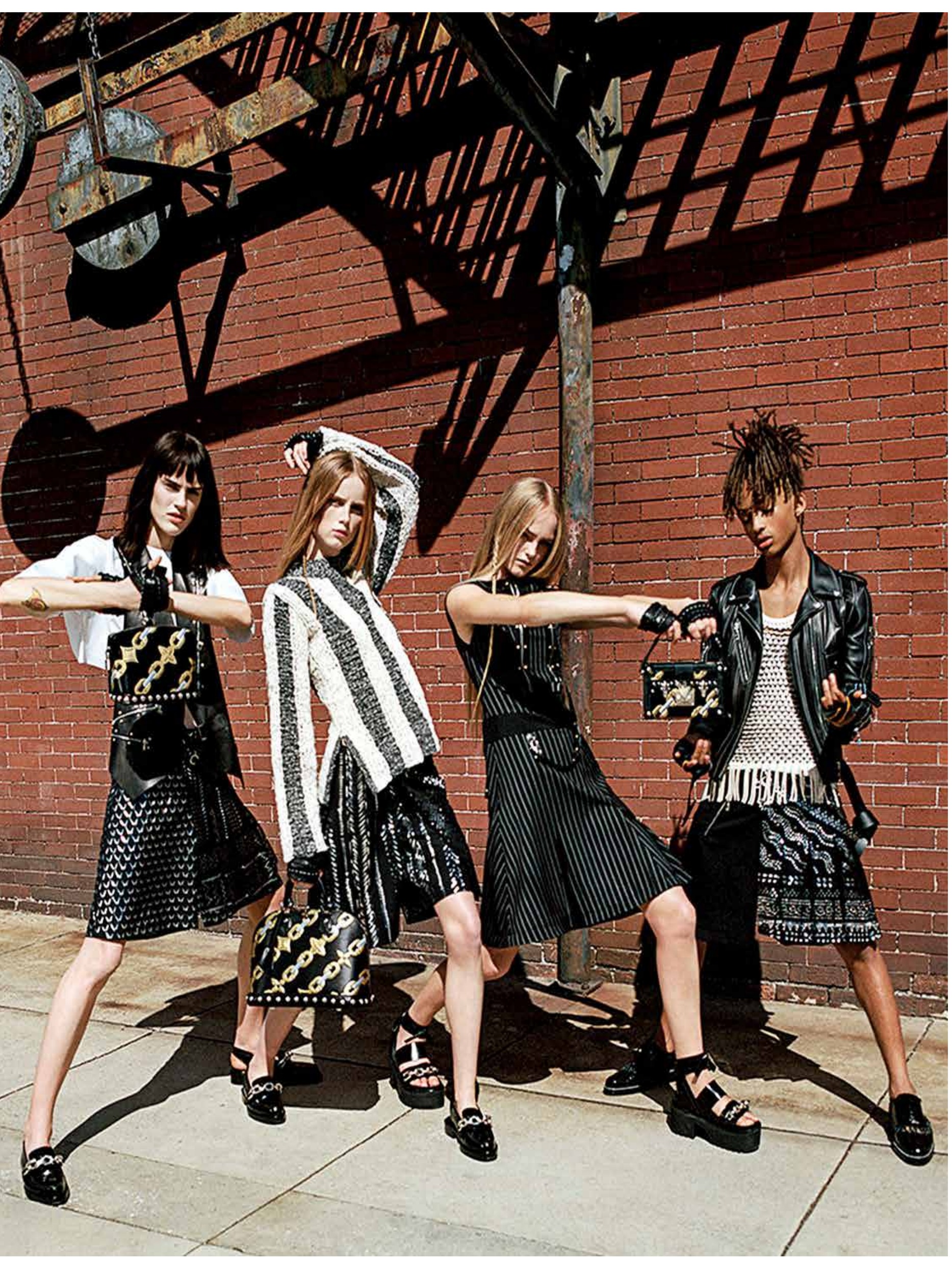

sendo parte de um segmento de luxo. Posicionar-se politicamente fortalece a sua imagem para o público jovem que ainda anseia por mudanças e procura construir sua identidade pertencendo a grupos que defendem alguma crença por igualdade, mesmo no desgastado panorama econômico global.

Apesar de tratar os corpos juvenis com os quais se associa, assumindo uma atitude de respeito às identidades de gênero, esse engajamento parece um tanto superficial e mais próximo de ser uma estratégia de marketing, em busca de um posicionamento alinhado com o seu público consumidor. A indústria de consumo de moda ainda está longe de lidar com corporiedades problemáticas, como as da anorexia e da obesidade ou mesmo em relação ao que se denomina plus size, diferenças que se enfrentam nos bastidores do consumo. Na Gucci, praticamente todos os modelos pertencem a um padrão de magreza e juventude convencionado como o ideal pelo universo fashion.

A marca Louis Vuitton também utilizou-se deste recurso com campanha de alta visibilidade ao convidar o jovem ator Jaden Smith para figurar como modelo de roupas femininas em 2016.

Ser jovem, magro e desejado ainda é o fio condutor de muitas das histórias inventadas pela marca e são esses os sujeitos que protagonizam as campanhas publicitárias. 


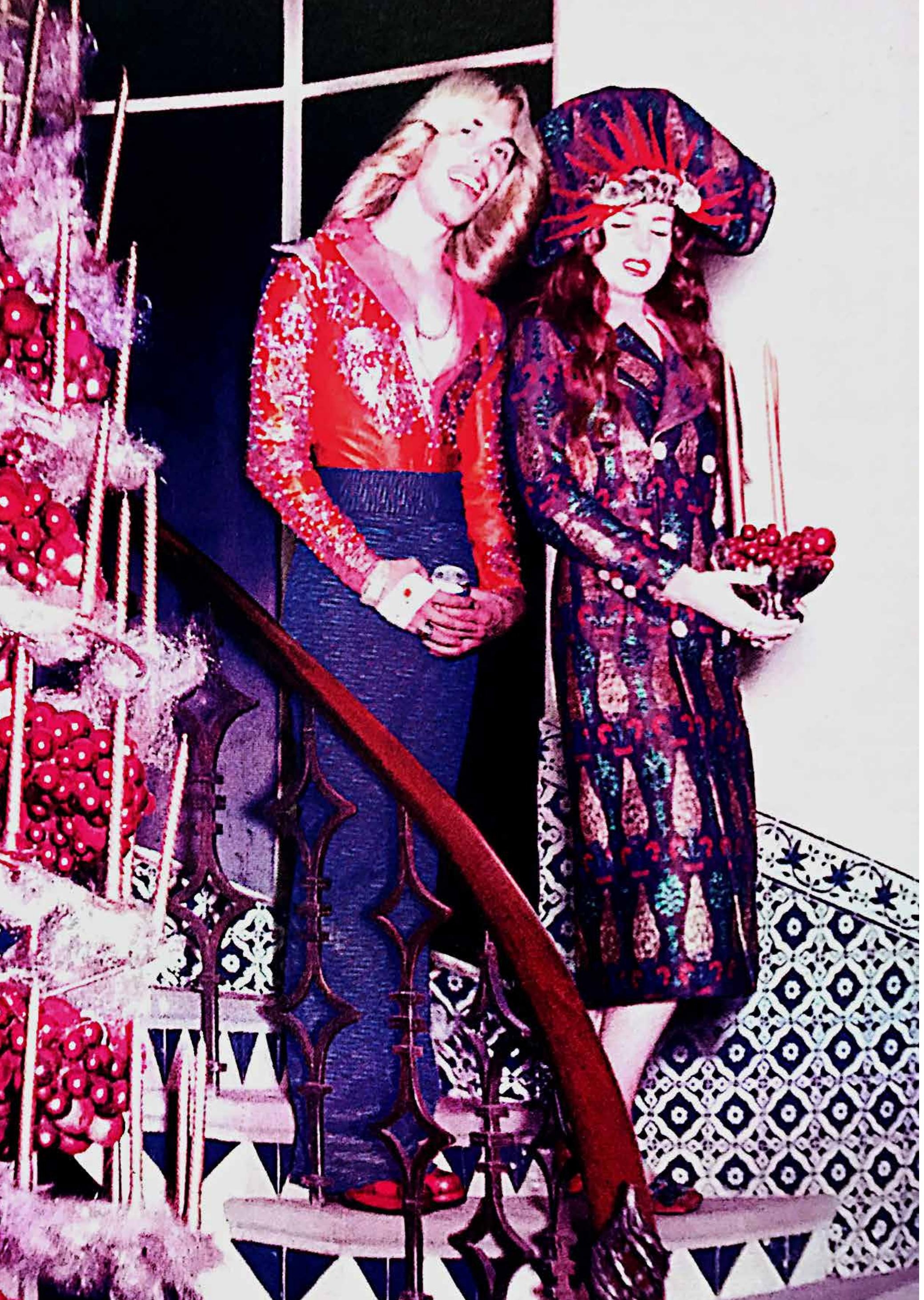

\section{Millennial}

Música e posicionamento político

A distinção e definição de público alvo, antes restrita a David LaChapelle idade, classe social e gênero, por aderência a discursos de marketing e publicitários, passa a ser caracterizada e classificada por gerações com agrupamentos que associam comportamentos comuns sem, necessariamente, identificar geograficamente cada grupo. Assim, Pop millennial representa a geração nascida a partir do ano 2000. Considerados nativos digitais, conceito de PRENSKY (2001) que contrapõe esta geração com a anterior a qual chama de Digital Immigrants, estes jovens consumidores apresentam uma série de características peculiares.

Sentem a necessidade de defender ou aderir a uma causa - social, política, de gênero, em defesa do meio ambiente, de animais, de florestas, de mares, do aquecimento global, etc. - mas sua atuação muitas vezes acontece pop em editorial da e fortalece a estratégia de estar presente en muitas plataformas de Revista alaunt, Los Angeles, EUA, 2017 
"A juventude de hoje já somente nas redes sociais e nas trocas digitais, por meio nasceu em um mundo que dos aplicativos de relacionamento. Posicionar-se publidemocratiza o design, antes camente por meios digitais implica em um trabalho de restrito a marcas de luxo. construção de reputação que requer interação e presença Isso causa pânico no varejo, constante nesses ambientes, de modo a mostrar-se em muito tombém porque esses atividade, conhecedor dos acontecimentos e com capaciclientes preferem comprar dade de tecer comentários.

online a ir numa loja que $\mathrm{O}$ registro de seguidores ou de likes de uma publicação nõo vai oferecer pode facilmente ultrapassar a casa de milhares. A comuexperiência nenhuma" nicação unidirecional, que era enviada pela marca ao conRony Rodrigues, Box 1824 sumidor, precisou ser revista. A geração millennial quer Pedro Diniz, Folha de São ser ouvida, quer ser reconhecida, quer afirmar-se, deixar Paulo, 22 nov 2017.. de ser consumidora de informação e assumir o papel de geradora de conteúdo.

O conceito de agenda setting (Maxwell McCombs e Donald Shaw, 1994) já não faz tanto sentido no mundo globalizado da comunicação digital e dos mecanismos da pós-verdade e das fake news, fenômeno de criação e manipulação de informações que pode influenciar pessoas em decisões políticas. Um dado que não é simplesmente matemático e que vem de uma rede de relacionamento capaz de agregar atributos de verdade ao dito, considerando acordos de confiança e de afeto entre amigos virtuais que se seguem e que, ao fazerem assim, cumprem um ritual expressivo baseado predominantemente em acordos civilizatórios que desencorajam opiniões fortes e desafiadoras, sob o risco de exporem ou serem expostos de forma desagradável no espaço público digital.

O like e o share se complementam e ampliam o poder de disseminação de modelos e modos de vida assim como das fake news. Compartilhar alguma informação em redes de relacionamento é dar crédito a ela e, por isso, os influenciadores tornaram-se potencialmente ameaças e objetos de desejo das grandes marcas. Compartilhar, de certa forma é também posicionar-se.
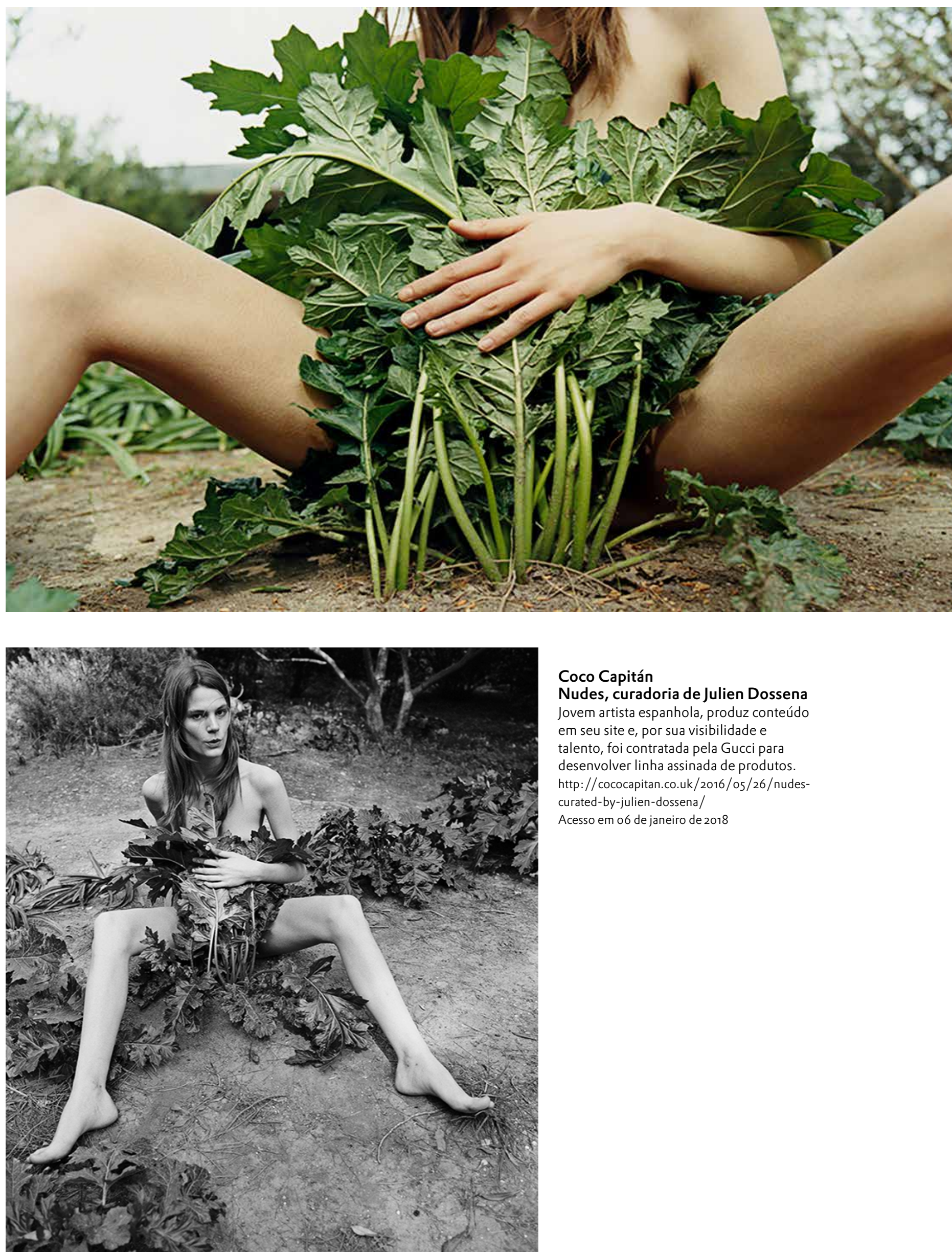

Coco Capitán

Nudes, curadoria de Julien Dossena

Jovem artista espanhola, produz conteér
em seu site e, por sua visibilidade e

talento, foi contratada pela Gucci para

desenvolver linha assinada de produtos.

http://cocococapitan.co.uk/2016/05/26/nudes-

curated-by-julien-dossena/
Acesso em 06 de jejeiro de 2080 


\section{WE JUST}

\section{WANTED TO \\ BE LOVED}

Coco Capitán A tecnologia digital ainda busca graus de lastro e de conFotografia do projeto pessoal disponivel fiabilidade da informação e dos big datas. Para o mercado

ç̄ōes utilizadas nas financeiro, por exemplo, a blockchain, uma tecnologia de

intervençōes Gucci
$0 \mathrm{k} / 2017 / 11 / 23 / \mathrm{bums}$ - $^{-}$ segurança de dados, afirma e defende a possibilidade de

um mundo financeiramente global num ambiente cuja resposta prometida é imediata e sem intermediários.

A tecnologia de dados que não permite que nada seja apagado promete segurança e rapidez nos processos. Tudo que for publicado ou lançado, permanece na rede. Informações são sobrepostas, datas de registro não podem ser alteradas. Isto implica novos comportamentos e compromissos, novos modos de se posicionar, de participar e de pôr-se ativamente como parte do sistema ou do ecossistema formado pelas tecnologias de informação e comunicação.

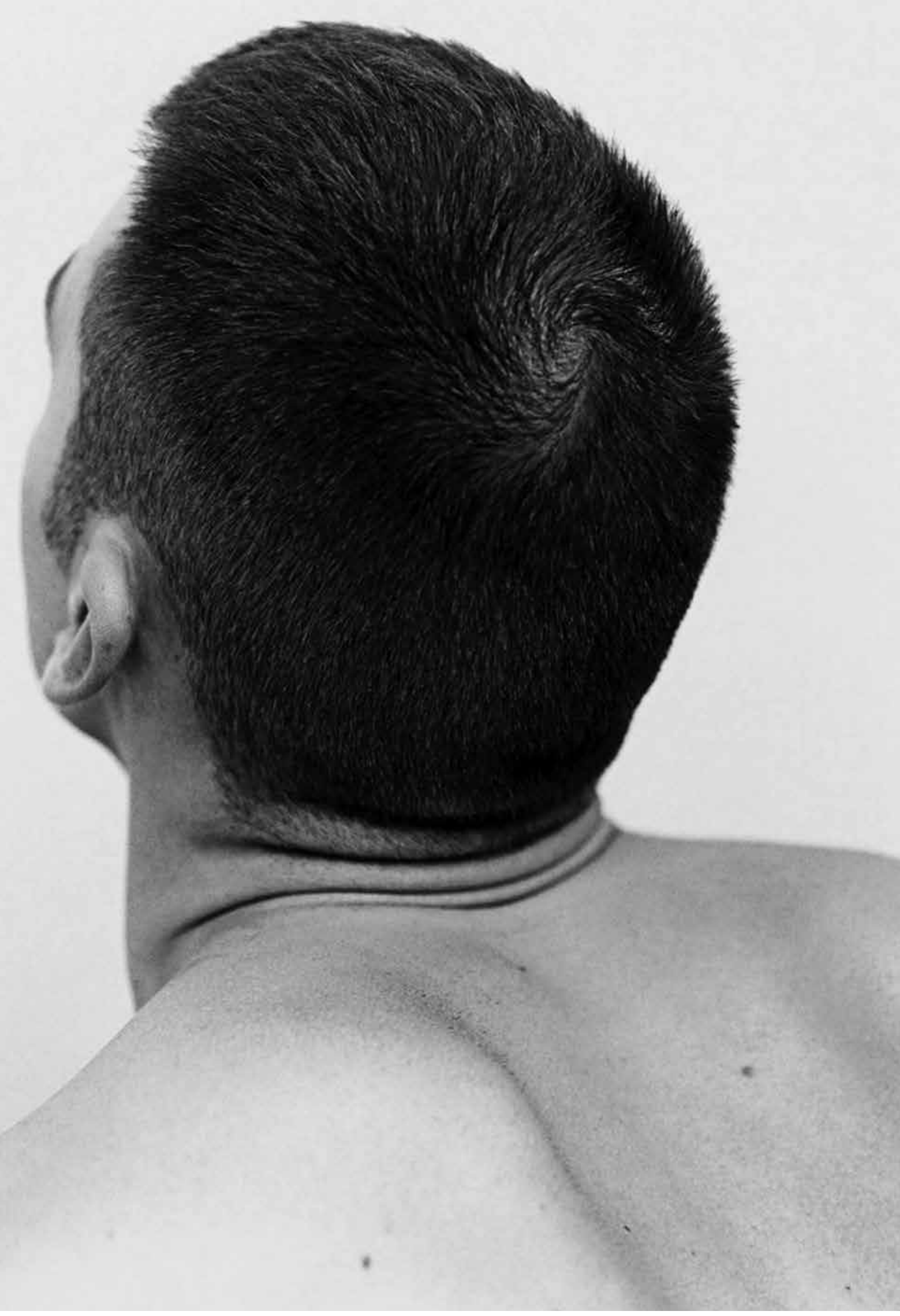




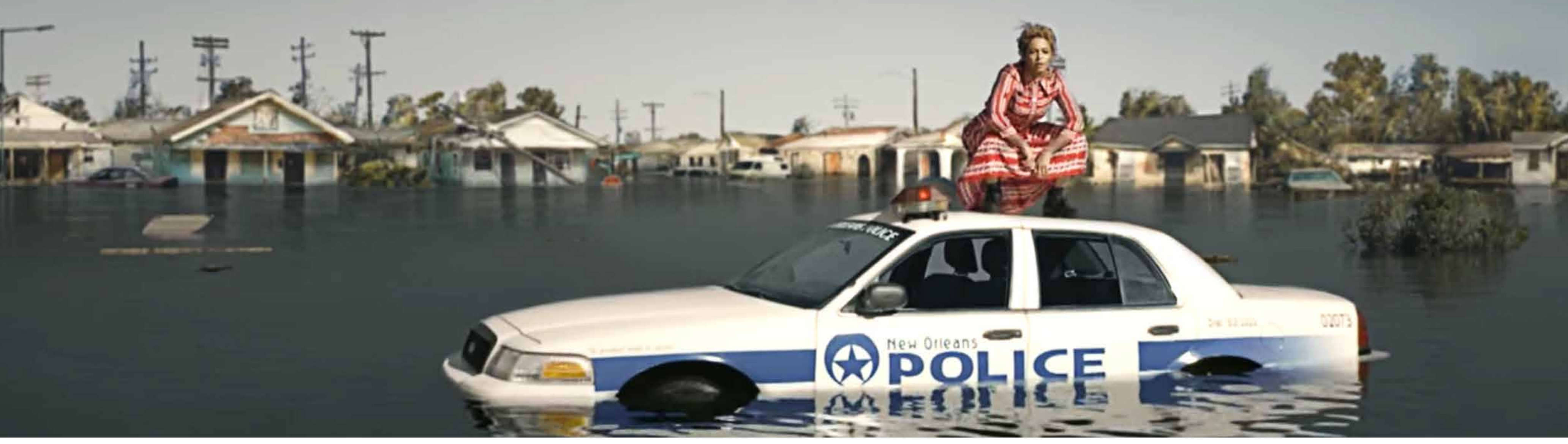

We are on a mission to "Estamos em uma missão para construir um futuro financeiro build a more open, mais aberto, acessível e justo, como uma parte de um softaccessible, and fair financial ware por vez. Nossa tecnologia está revolucionando a indúsfuture, one piece of tria de serviços financeiros por capacitar milhões em todo software at a time. o mundo para autenticar e negociar imediatamente e sem Our technology is custos intermediários"

revolutionizing the financial Blockchain

services industry by

empowering millions across Tradução livre

the globe to authenticate

and transact immediately

and without costly

intermediaries.

www.blockchain.com
Em meio a diferentes dinâmicas para reconhecimento e construção de reputação e credibilidade, a associação da Gucci com a cantora pop Beyoncé, além de uma estratégia publicitária comum no mundo da moda, traz um posicionamento político que busca apresentar de modo global o alinhamento com o que defende a estrela americana. No CD Formation, 2017, com música com mesmo título, Beyoncé, que aparece em segundo lugar entre as celebridades mais bem pagas do mundo, segundo a revista Forbes, fala em nome de uma grande parcela da população negra e jovem excluída e marginalizada política e socialmente.

[https://www.forbes.com/profile/beyonce-knowles/

Acesso em 17 jan 2018]

As letras de suas músicas e as narrativas que estruturam o roteiro de seus clipes são verdadeiros manifestos em defesa dessa população periférica dos Estados Unidos e
Beyoncé
Formation

Imagem capturada do videoclip Formation dirigido por Melina Matsoukas https: //www.youtube.com/ Watch? $v=W D Z J P V \vee b C$
Acesso em oz de nov 2017 
encontram eco no mundo, a partir da disponibilização nas mídias digitais, espalhando o seu discurso para além de qualquer fronteira de língua ou de cultura. Na abertura e no encerramento do clip "Formation", visto 79.571.871 vezes até 03 de novembro de 2017, ela aparece sobre um carro de polícia que submerge em uma área urbana alagada, posicionando-se contra as ações violentas e preconceituosas do estado e da força policial em diferentes regiões norte-americanas

Ao estabelecer uma parceria com a cantora, a Gucci posiciona-se publicamente defendendo também mais uma causa social, construindo assim, os valores que a marca representa, defende ou apoia.

O posicionamento político não se configura como única estratégia de defender os valores da marca, somam-se a este, histórias oníricas e fantásticas em editoriais digi- tais que trazem modelos envolvidos em cenários doces

e floridos. Realidade e fantasia se misturam e criam um lugar utópico em busca da adesão dos consumidores. Um mundo colorido e "perfeitinho" onde todos transitam entre o tédio e uma felicidade aparente. O ciclo entre consumir uma imagem e consumir uma peça de vestuário estreita-se e se confunde. Viver a imagem e sonhar vestir-se para aventuras imaginadas, seduz tanto quanto consumir efetivamente o produto.

O consumo torna-se midiático e voraz, o volume de informações disponível a cada segundo quase foge do controle, a aceleração provoca ansiedade e a sensação de que algo sempre se perde. Abre-se um novo ciclo, consumir o que se vê, não ver o suficiente, querer consumir mais e mais.

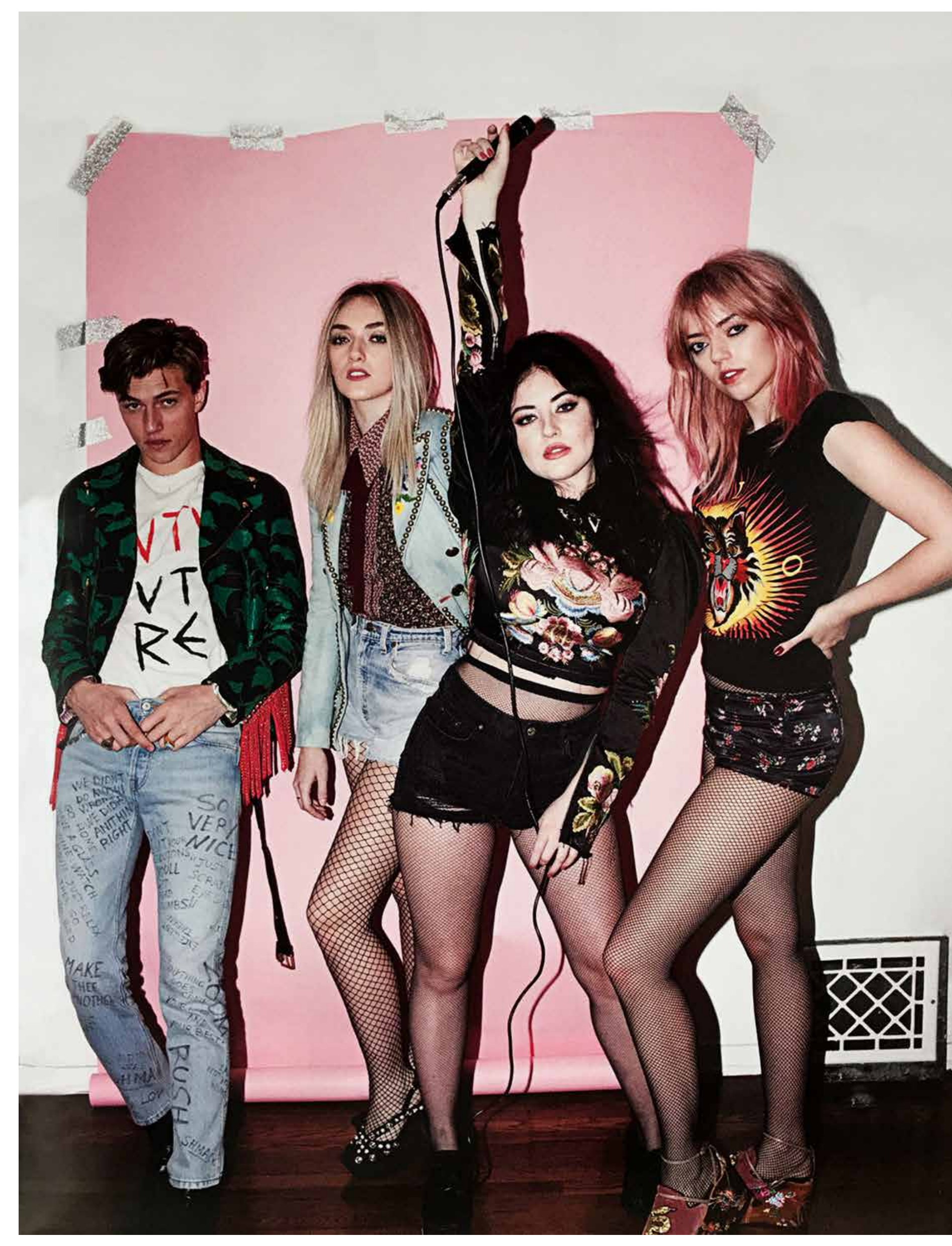




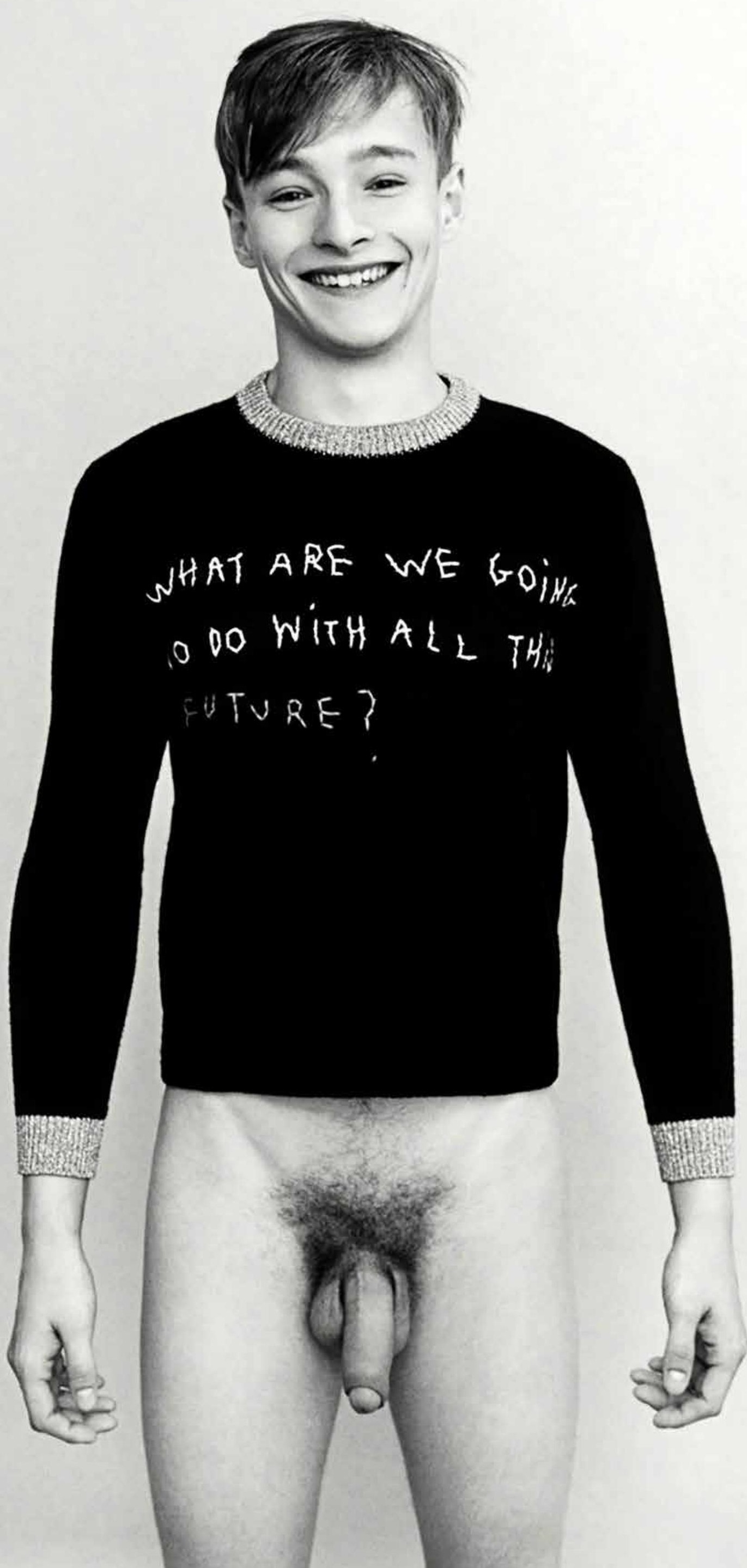

\section{Pixo de luxo}

Transgressão autorizada

A apropriação cultural das manifestações nas ruas e o combate à pirataria tiveram tratamentos diferenciados pela equipe criativa da marca. Ao invés de confrontar e processar artistas e designers por direitos autorais ou de uso de imagem, a Gucci contrata pichadores para criarem algumas séries de produtos assinados e com tiragem limitada. A pichação do espaço público se transforma em grafismo impresso nas roupas. Com a dinâmica de produção em tiragem limitada, essas peças ganham status de exclusividade e aumentam o valor de venda. A tática envolveu Trouble Andrew, cantor, compositor e artista visual, e Coco Capitán, artista espanhola de rua, pichadora e poeta visual. A interferência gráfica nas roupas impressas, reforçam uma rebeldia domesticada e sob controle. Uma linguagem visualmente suja ou tosca, pouco preocupada com a legibilidade e com a compreensão do



Acima è̀ esquerda

Coco Capitán

Botografias do projeto disponíveis

site da artista

hittp://cococapitan.co. uk/2017/11/23/buns-

Anssost/ 

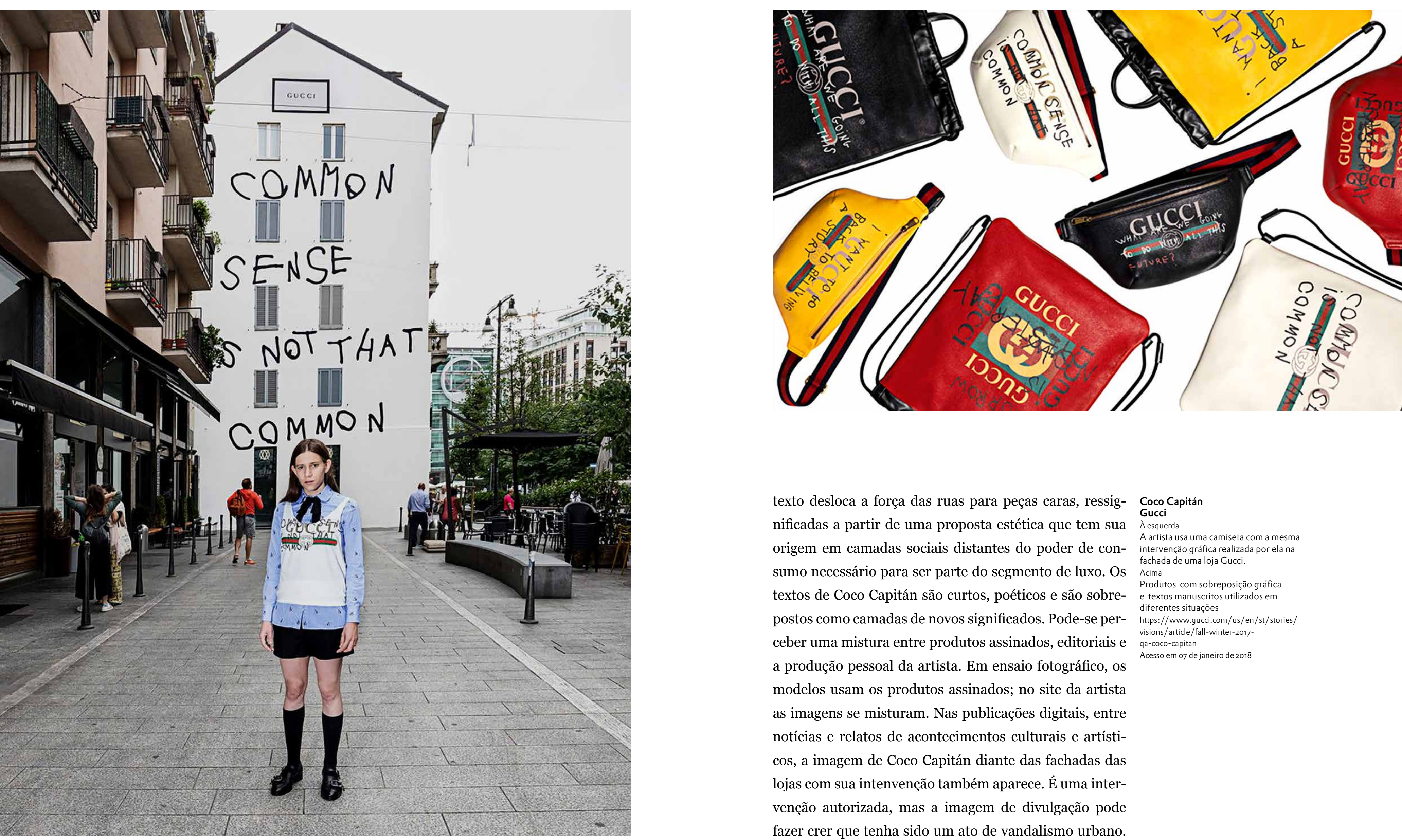

texto desloca a força das ruas para peças caras, ressig- Coco Capitán nificadas a partir de uma proposta estética que tem sua origem em camadas sociais distantes do poder de consumo necessário para ser parte do segmento de luxo. Os textos de Coco Capitán são curtos, poéticos e são sobrepostos como camadas de novos significados. Pode-se perceber uma mistura entre produtos assinados, editoriais e a produção pessoal da artista. Em ensaio fotográfico, os modelos usam os produtos assinados; no site da artista as imagens se misturam. Nas publicações digitais, entre notícias e relatos de acontecimentos culturais e artísticos, a imagem de Coco Capitán diante das fachadas das lojas com sua intenvenção também aparece. É uma intervenção autorizada, mas a imagem de divulgação pode fazer crer que tenha sido um ato de vandalismo urbano.

À esquerda intervenção gráaica realizada por ela na

Produtos com sobreposicão gráfica diferentes situações $/$ /us/en/stories/ hips://www.gucci.com/us/en/st/stories/ qa-coco-capitan -winter-2017- 

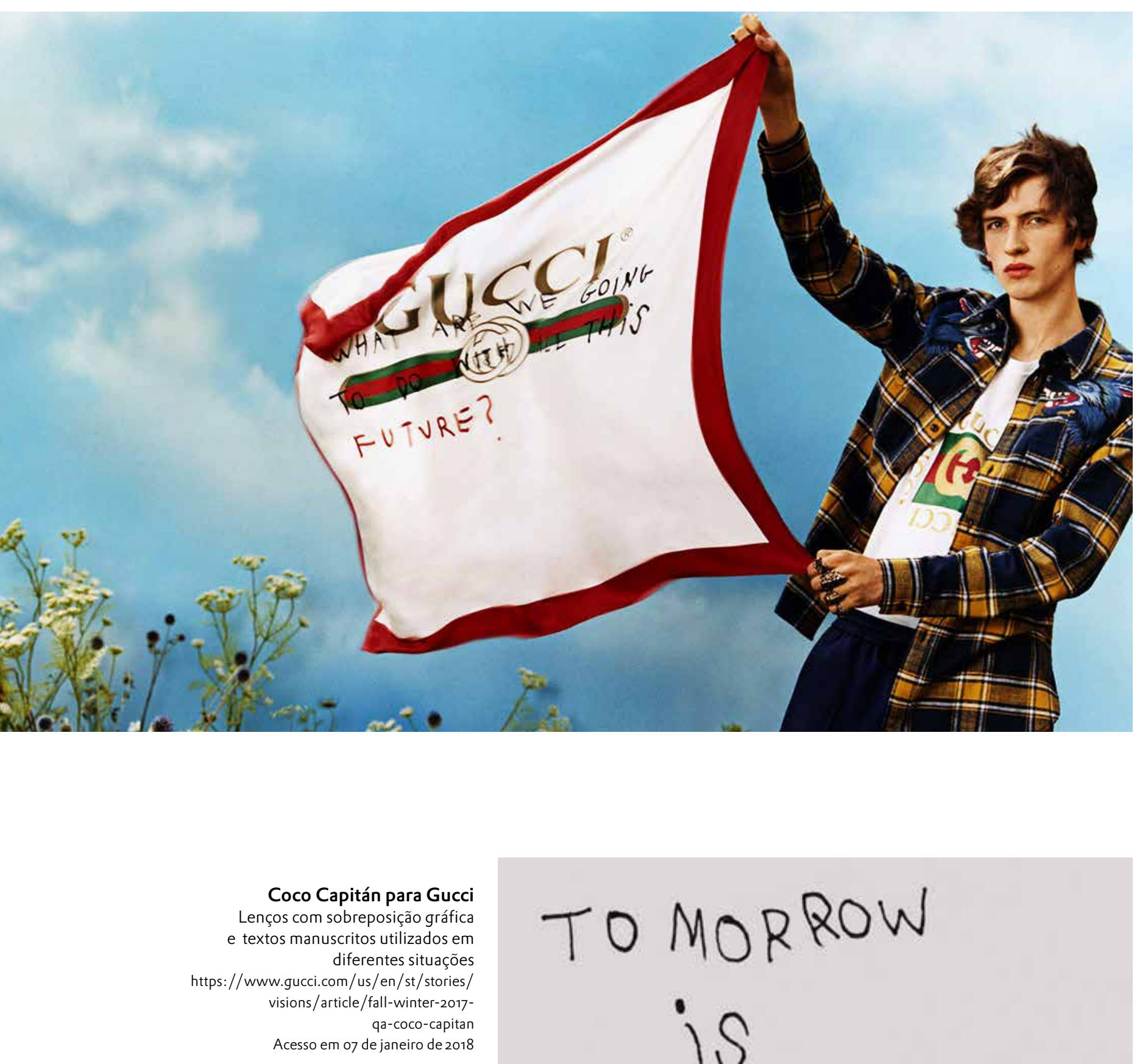

TO MORROW

is

NQTERDAY
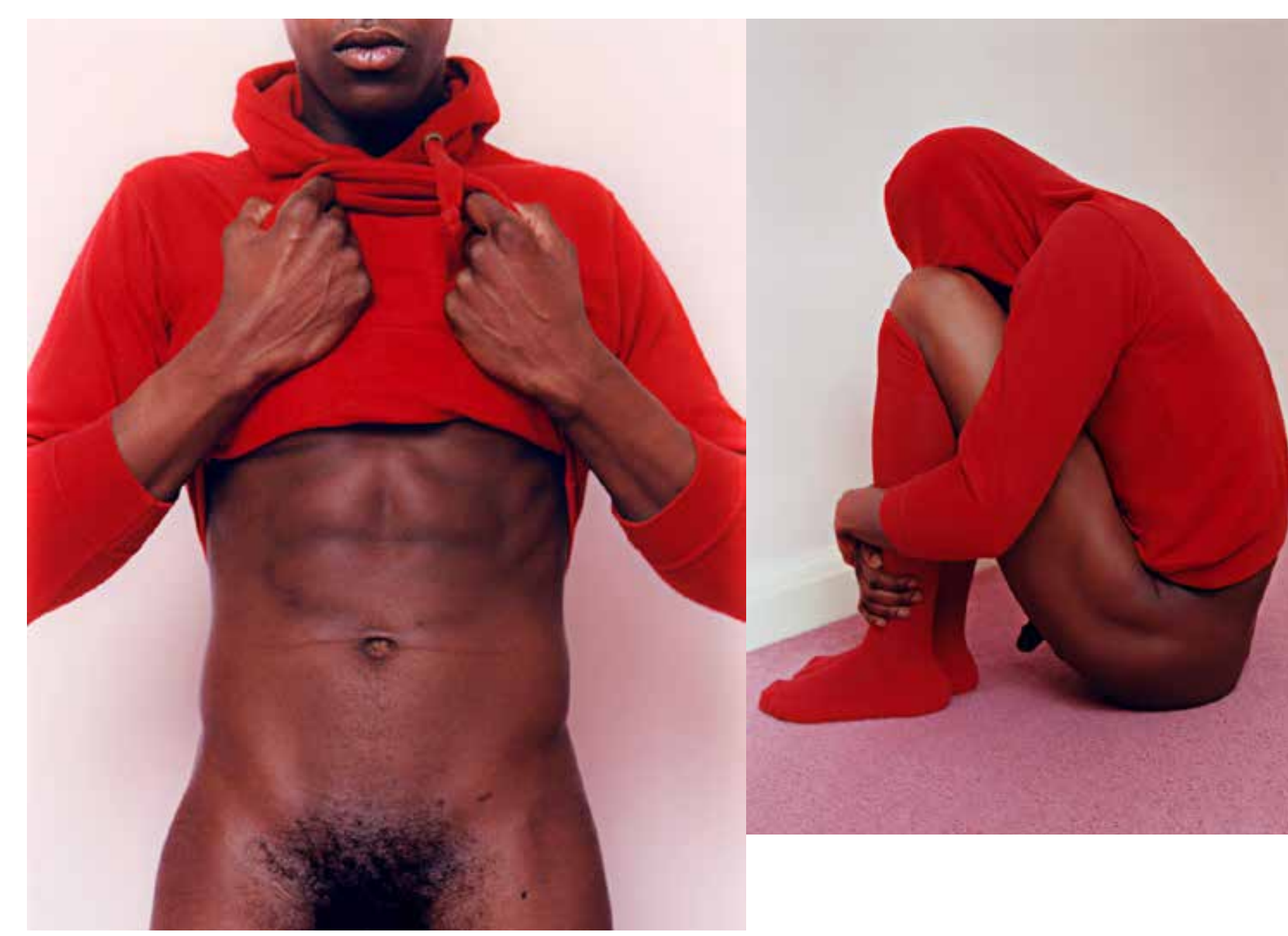

Legitima-se novamente um discurso de rebeldia não só consentida, mas sob encomenda. Os detratores da marca se aproximam dela e a incorporam como objetos de desejo.

Passado, futuro e presente, sim e não, coexistem as multiplicidades de polaridades e de combinatórias. As contradições e incertezas ganham espaço e se sobrepõem às imagens clássicas da marca.

Reescrever sobre a roupa impressa ou bordada implica em uma rebeldia e uma atitude de confronto. É como se estivesse a dizer: Eu nego e aceito a marca. Reconheço sua qualidade e sua tradição, mas registro sobre ela meu parecer e meu desejo de futuro, minha insatisfação e inquietação. Utilizo-me da visibilidade que a marca pode proporcionar e me beneficio dela.
Coco Capitán

ms and tums in dust

Cecrial de moda, notícias e produçẫo pessoal da jovem artista aparecem sem
fronteiras entre cada tipo de informaçăo ou cada obra.
http: // cococapitan.co.uk/2017/11/23/bums. Acesso em 06 de janeiro de 2018 


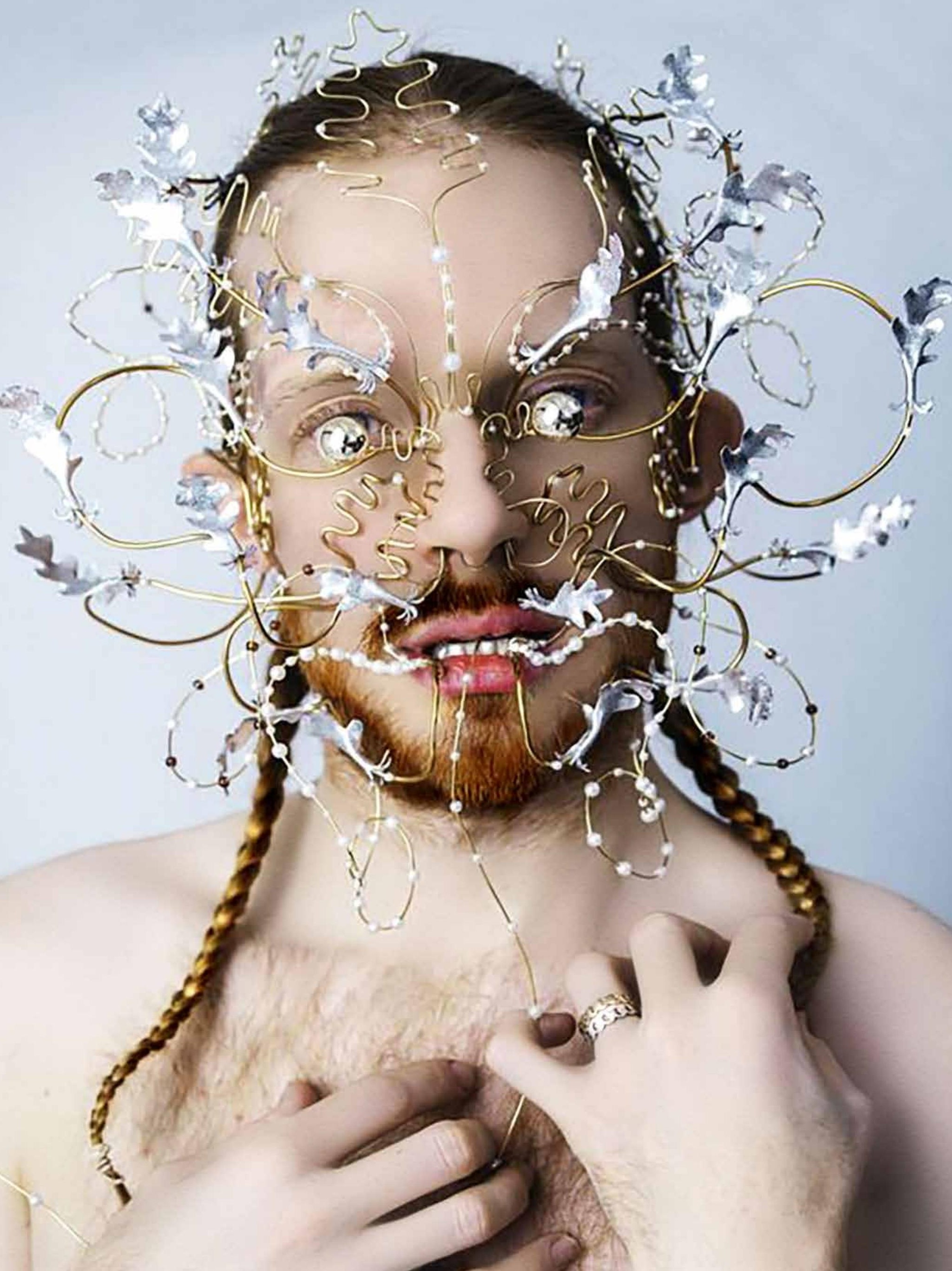

\section{Campanhas nonsense} Histórias reais inventadas

A tradição e herança da Gucci dão lugar a histórias inventadas. Isto se reflete nas ações de comunicação, não só nas plataformas de e-commerce, mas nas plataformas de redes sociais e de conteúdo. O próprio estilo das roupas que simulam desgaste, rasgos e 'consertos' contam histórias inventadas.

Por saber que a sustentabilidade é um item importante para o público alvo, a Gucci posiciona-se em defesa dos meios de produção e do meio ambiente, porém, desconsidera, ou não comunica, os meios industriais de envelhecimento de jeans e desgaste simulado, característica comum em muitas de suas peças.

A Gucci posicionou-se também contra o uso de peles naturais em seus produtos, passando a selecionar e buscar produção de peles e couro artificiais.
James Merry para a cantora Björk Fotografia de Tim Wal para LD Magazine hitp: // www.ttmerry.com/l 
Nessa perspectiva, é para um olhar expandido que se dirigem as decisões criativas e de divulgação construídas a partir e para a rede digital de informação e comunicação que torna a simultaneidade uma experiência tecnológica comum. Esse olhar, que transita por todo o planeta, não encontra um lugar de fixação e foco. Ansioso por novidades, ameaçado pela possibilidade de ser mais um entre todos, esse sujeito que olha se sente instigado a agir rápida e objetivamente, seduzido por personagens tornados visíveis a partir das imagens digitais que constroem sobre si mesmos e sobre suas idiossincrasias, personagens apropriados e ampliados pelo poder da marca de despertar interesse.

Esse imaginário se torna também instantâneo, na medida em que novas imagens surgem sobre as originárias que recuam para dentro de si mesmas e de seu universo de existência, antes restrito à rede de quem as acessava cia é de se localizar entre o universal e o distinto, se coloca - não somente como uma disputa de classe, na medida em que os elementos de distinção ao serem apropriados por classes sociais menos favorecidas devem ser imediatamente substituídos - como uma espécie de corrida cujo tempo entre o consumo e o uso se tornam progressivamente mais urgentes. A marca provoca imaginários efêmeros, como efêmeras são as imagens que propõe como tendência ou estilo de vida. Ver e consumir se tornam pares indissociáveis, resta superar o tempo/espaço que separa a escolha/compra do recebimento da mercadoria/marca na porta de casa.
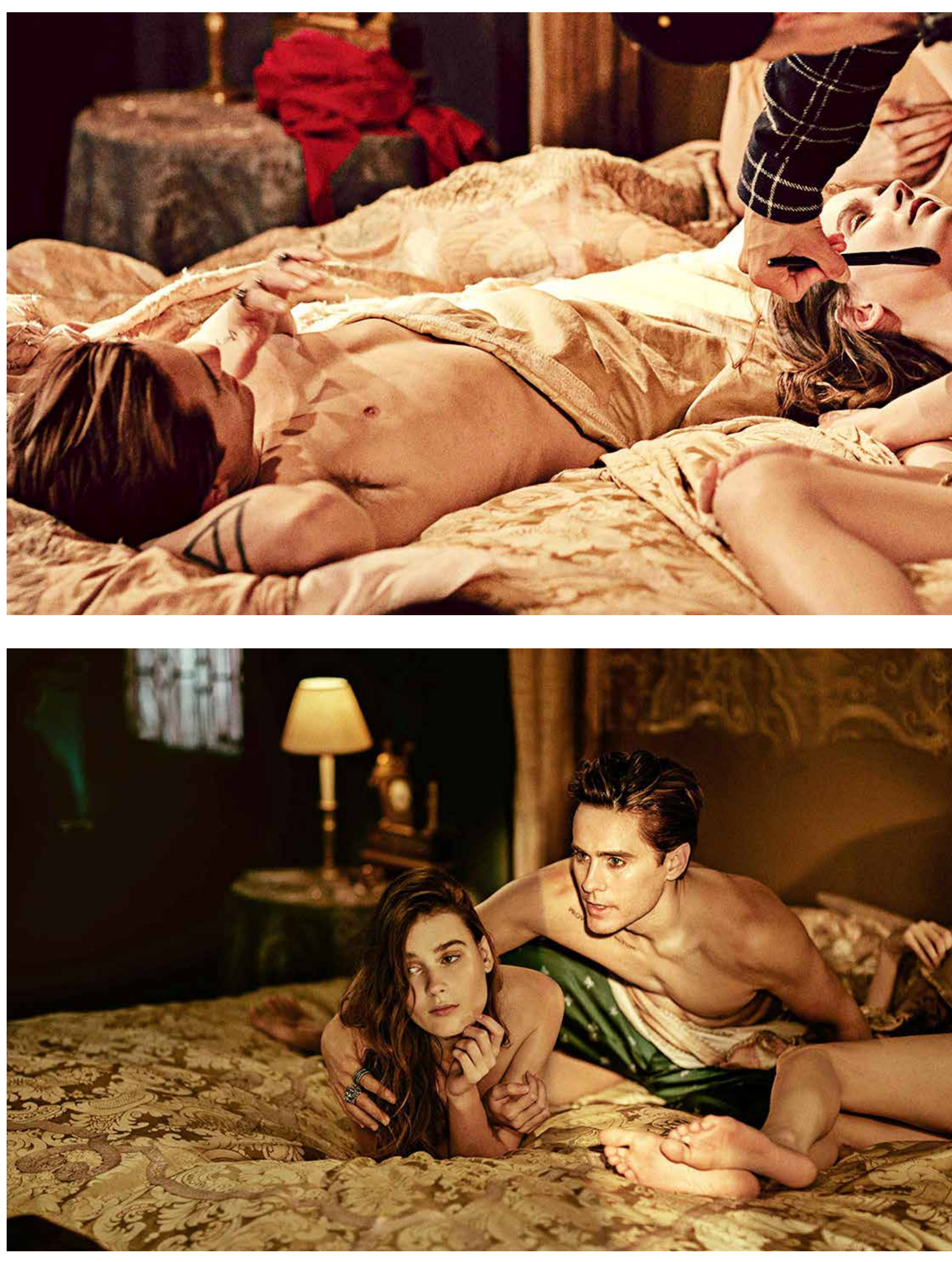
Um exemplo da estratégia de dar visibilidade a personagens reais ou inventados é a história de Adrian Kozakiewicz, jovem criador de animais e colecionador, apaixonado por insetos:

Entomophobia. A peculiar reason why Adrian Kozakiewicz's $265+k$ followers on Instagram are drawn to watching his posts of weird insects crawling over his face.

"It's like shock therapy, I often hear people are no longer afraid of insects after seeing my videos," said the 20-year-old insect breeder, one of the biggest in Europe. "It's something very strange that I do, which no one else does, these spectacular animals which people have never seen before." Kozakiewicz breeds around 50 species of insects in a 25 m.sq space in his home in Karlsruhe, South-West Germany. Among them, the red and black beetle Mecynorhina ugandensis, which appears printed on a Gucci bag from the Fall Winter 2017 collection; and the iridescent Phalacrognathus muelleri (Rainbow Stag Beetle) which Alessandro Michele designed crafted in metal as a bauble for pearl necklaces and on GG Marmont bags. Kozakiewicz's preferred bug is the mantis, which he describes as the ninja of the insect world.

Entomophobia. Uma razão peculiar por que os seguidores, mais de 265 mil pessoas, de Adrian Kozakiewicz no Instagram são atraídos a assistir suas postagens de insetos estranhos rastejando sobre seu rosto.

"É como uma terapia de choque, muitas vezes ouço que as pessoas já não temem os insetos depois de ver meus vídeos", disse o criador de insetos de 20 anos, um dos maiores da Europa.

"É algo muito estranho que eu faça, que ninguém mais faz, esses animais espetaculares que as pessoas nunca viram antes". Kozakiewicz gerencia cerca de 50 espécies de insetos em um espaço de 25 metros

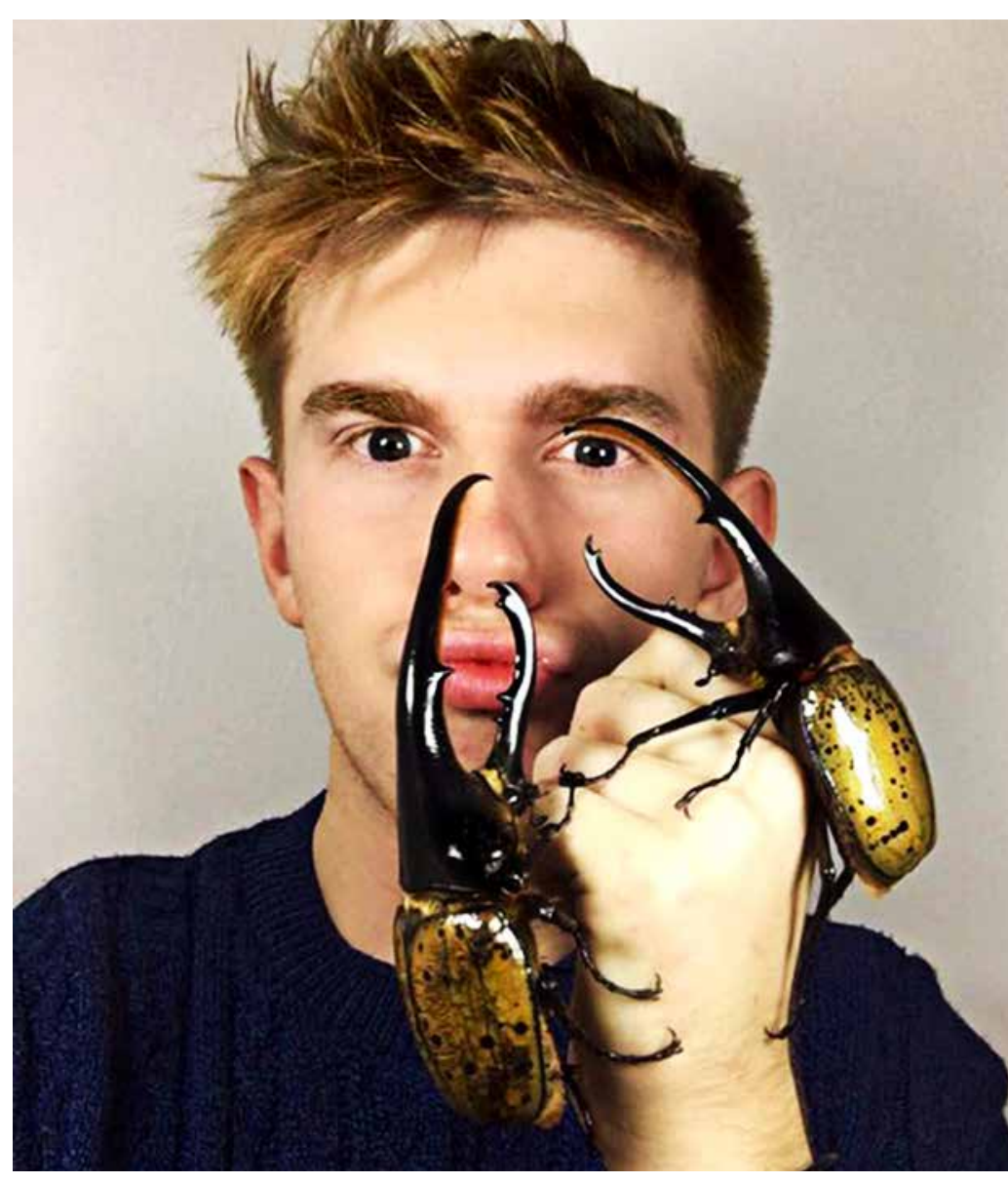

Each species of the mantis perfectly adapts to their habitat, like everything in nature some species look like sticks, grass, green leaves, dead leaves, stones or bark - also how they prey and eat their food, they eat other insects.

quadrados na sua casa em Karlsruhe, no sudoeste da Alemanha. Entre eles, o besouro vermelho e preto Mecynorhina ugandensis, que aparece impresso em um saco Gucci da coleção Fall Winter 2017; e o iridiscente Phalacrognathus muelleri que Alessandro Michele projetou em metal como fecho para colares de pérolas e em bolsas GG Marmont. O inseto preferido de Kozakiewicz é o louva-deus, que ele descreve como o ninja do mundo dos insetos.

Tradução livre

Os mais de 265 mil seguidores do jovem na plataforma Instagram, provavelmente despertaram o interesse da marca em contar sua história em suas redes de comunicação. A beleza dos insetos inspirou a criação de uma coleção com broches e aplicações em metais e pérolas que
"Cada espécie de louva-deus se adapta perfeitamente ao seu habitat, como tudo no atureza, algumas espécies se parecem com palitos, grama, folhas verdes, folhas mortas, pedras ou cascas também como eles capturam e comem seus alimentos, eles são predatores de outros insetos"

Adrian Kozakiewicz

As fotografias se misturam em diferentes plataformas
site da Guce visions/article /fall-witer/ent/st/stories/ shoppable
Acesso em os de novembro de 2017 

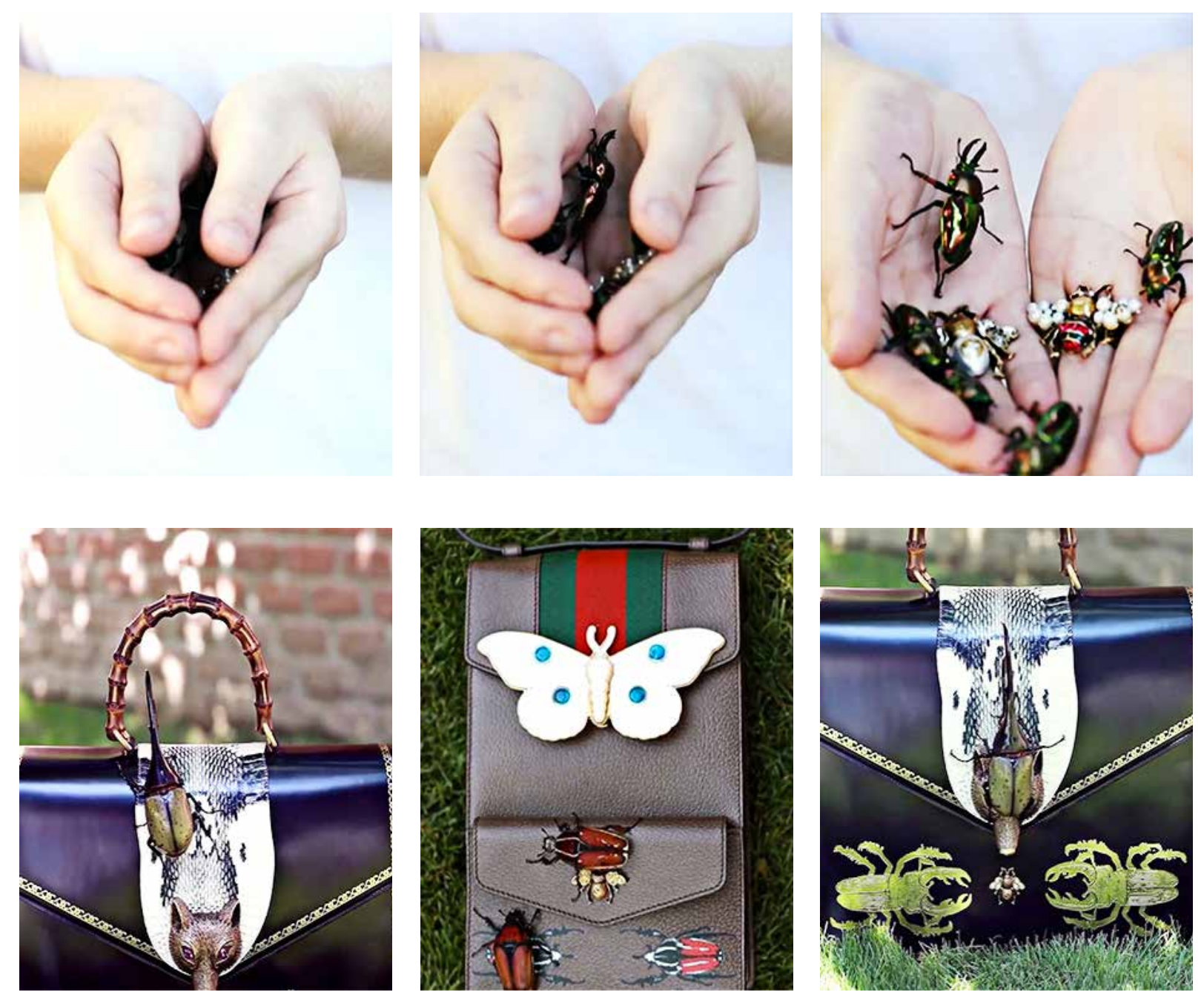

Adrian Kozakiewicz servem de adorno para cintos, bolsas e outros acessórios. inspirada nos insetos. A curadoria de conteúdos, também sob a coordenação de https://www.gucci.com/us/ no $/$ s Alessandro Michele, explora e otimiza o potencial fantástico do colecionador e transforma a coleção do jovem Kozakiewicz em mercadoria e matérias de comunicação.

Outro exemplo das histórias que compõem o menu Stories do site Gucci é o trabalho de James Merry, jovem artista inglês que faz as máscaras da cantora islandesa Björk. Além dos acessórios e de direção de arte de alguns videoclips da cantora, Merry faz intervenções por meio de bordados em roupas de marcas, geralmente esportivas. Assim, pode-se comprar em seu site camisetas, blusas de malha e outras peças de vestuário de diferentes marcas com bordados sobrepostos.
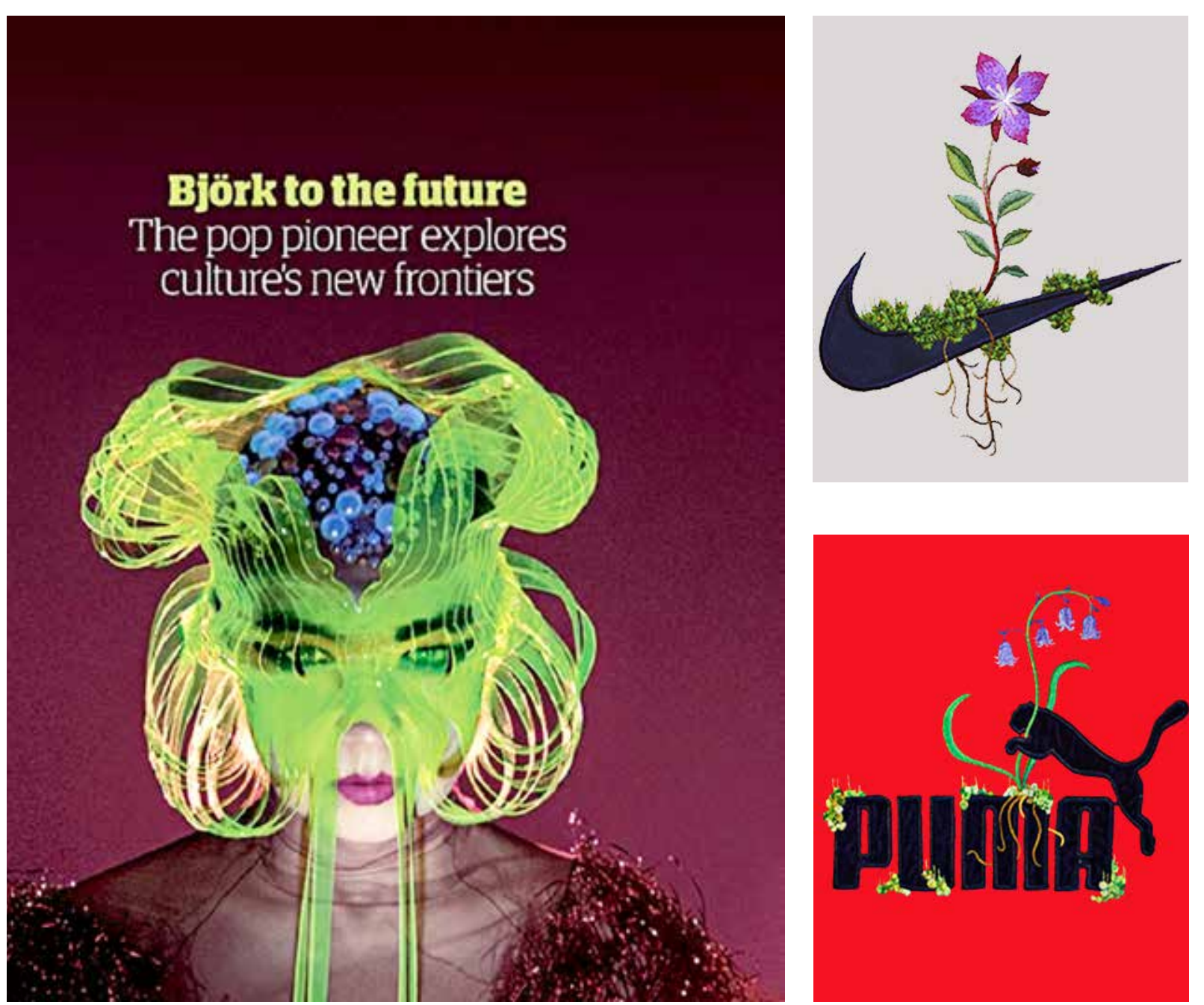

Björk procura fugir de padrões, quaisquer que sejam eles. Sua música tem um caráter experimental que busca dissonância como forma de estruturar a harmonia, criando ritmos incomuns o que provoca um certo estranhamento no resultado e que agrada seu público fiel. Relacionou-se por bastante tempo com Matthew Barney, artista performático e renomado videomaker com trabalho marcadamente contemporâneo e inovador. Neste contexto, seu trabalho contribuiu para que James Merry obtivesse o destaque e a visibilidade necessários nos meios digitais para tornar-se uma das Stories do site Gucci. Identifica-se uma recorrência que leva a um padrão: visibilidade promove sucesso para a marca.

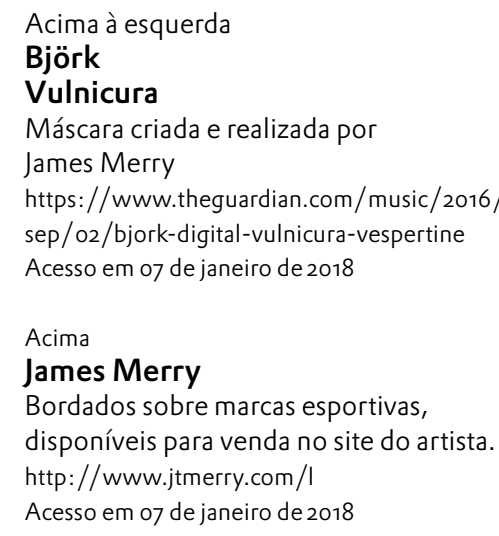

Acima à esquerda

Björk Máscara criada e realizada por James Merry Ths.//mWh/heguardian.com/music/2016/ Acesso en 07 dejaneiro de 20 -vespertine Acima Bordados sobre marcas esportivas, htpp.//wwwitmerry.com/1 Acesso em o7 de janeiro de 2018 


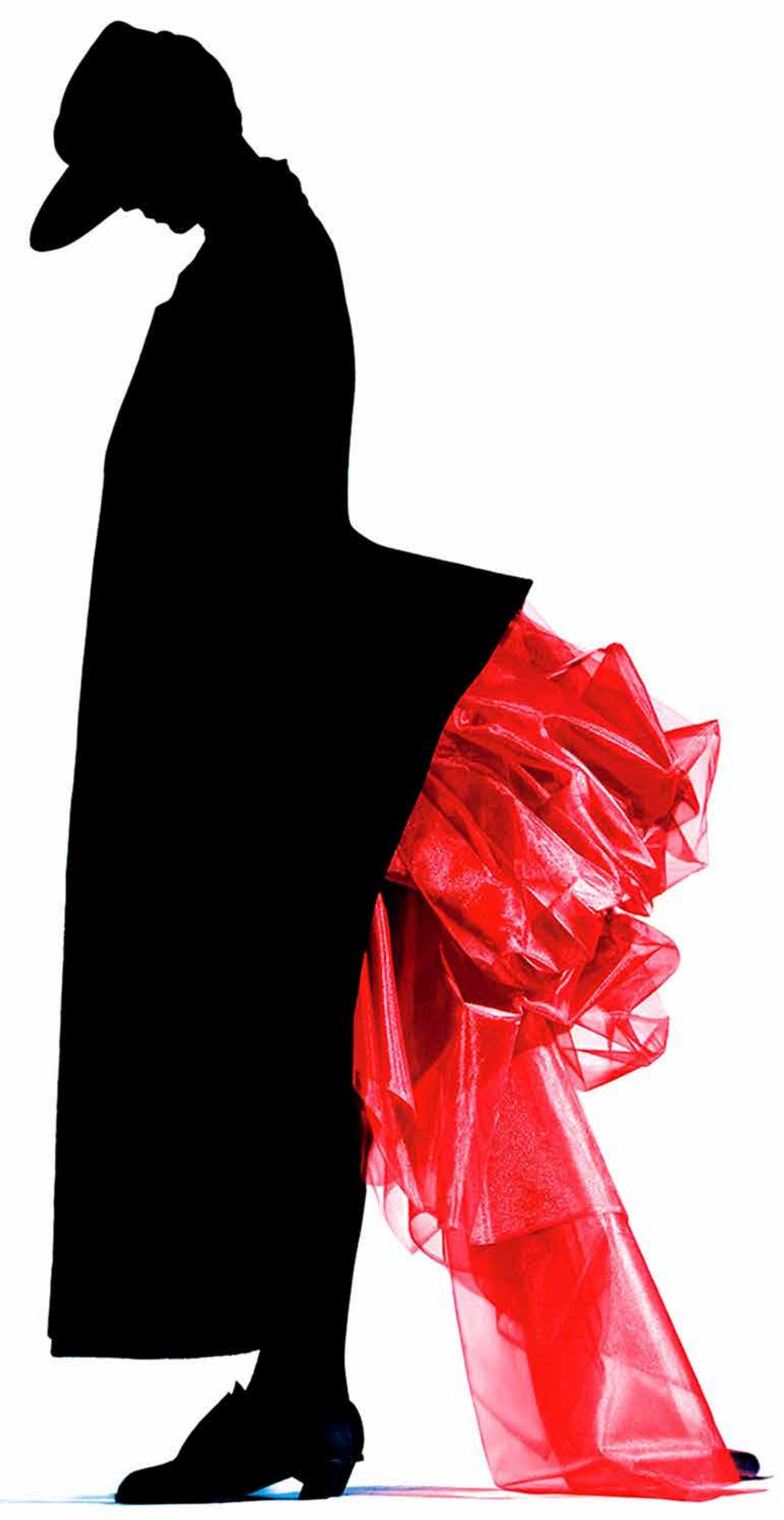

\section{Reforma on-line \\ O consumo digital de objetos}

Dentre as estratégias de ampliar as vendas, a marca Gucci associou-se a empresa britânica Farfetch.

\section{Nick Knight}

Yohji Yamamoto, 1986

Depois de utilizadas em campanhas

e materiais promocionais o fotógrafo

"Lançada em Londres em 2008 pelo empreendedor português disponibiliza as imagens ampliadas en

Chegamos às manchetes em 2016, quando concluímos uma rodada de investimentos de US\$110 milhões. Hoje avaliada em US\$1 bilhão, a Farfetch está entre os líderes pioneiros da indústria da moda - queremos criar a experiência de compra do futuro, com o cliente no centro de tudo".

https://www.farfetch.com/br

A promessa de entrega imediata e sem custos e o fato de ser uma plataforma multimarcas, todas de luxo, parece atrair o público jovem de classe alta. As características 


\section{Alexander McQueen \\ Belos imperfeitos}

As discussões sobre o corpo como ferramenta política Alexander McQueen ainda não estavam em evidência quando Lee Alexander McQueen provocou indignação e espanto no mundo Wicon, Claire, Alexander McQueen. Vatadin fashion. Nascido em 1969 em Lewisham, Londres, aos 16 anos iniciou-se no trabalho como estagiário de alfaiataria masculina na rua Savile Row. Posteriormente passou a trabalhar na fábrica Angel and Bermans, especializada em figurinos de teatro e cinema. O domínio técnico advindo do aprendizado de roupas sob medida e a possibilidade de confeccionar trajes especiais para a fantasia do teatro e do cinema, contribuíram na sua formação e parece ter potencializado seu talento como designer de moda. Sua experiência profissional na Angel and Bermans pode ter mudado sua relação com o tempo. Com figurinos de época aprendeu técnicas clássicas e 
permitiu-lhe resgatar métodos em desuso para fazer roupas. Em 1992 terminou seu mestrado na Central Saint Martin's College e criou uma marca própria. Em 1994 com 25 anos, realizava desfiles e apresentações de coleções que fugiam às regras e do sistema da moda e impactava o cenário mundial da área.

Sua originalidade levou-o a ser convidado para atuar como diretor criativo da Maison Givanchy, que pertence ao grupo Louis Vuitton, de 1996 até 2001 e posteriormente na Casa Gucci. A marca Alexander McQueen, por sua vez, foi adquirida em $51 \%$ pelo grupo detentor da Gucci no ano 200o. Percebe-se que desde este período os empreendimentos de moda da Gucci, desenhavam estratégias para diferenciar-se de outras buscando por profissional jovem e inovador.

A abordagem de McQueen com o corpo feminino desAlexander McQueen The /ace Magazine, Nick Knight, 1998 hittp: //www.gq-magazine.co.uk/achice
face-magazine-story
Acesso em 20 ianeiro 208 loca o sentido usual do perfil e silhueta desejados e dentro do padrão da moda para um universo que solicita, de forma radical e sem concessões, o envolvimento de corpos e mentes, tanto dos modelos quanto do público. Estes se deparam com uma performance que os exige a partir de uma postura menos baseada no olhar e no visual do que numa experiência tátil. No livro Os olhos da pele (2011) do arquiteto finlandês Juhani Pallasmaa a percepção do mundo se livra dos ditames da especialização e é assim tratada:

"O tato é o modo sensorial que integra nossa experiência de mundo com nossa individualidade. Até mesmo as percepções visuais se mesclam e interagem no continuum tátil da individualidade; meu corpo me faz lembrar quem eu sou e onde me localizo no mundo. Meu corpo é o verdadeiro umbigo de meu mundo, não no sentido de ponto de vista da perspectiva central, mas como o próprio local de referência, memória, imaginação e integração." (p.11)

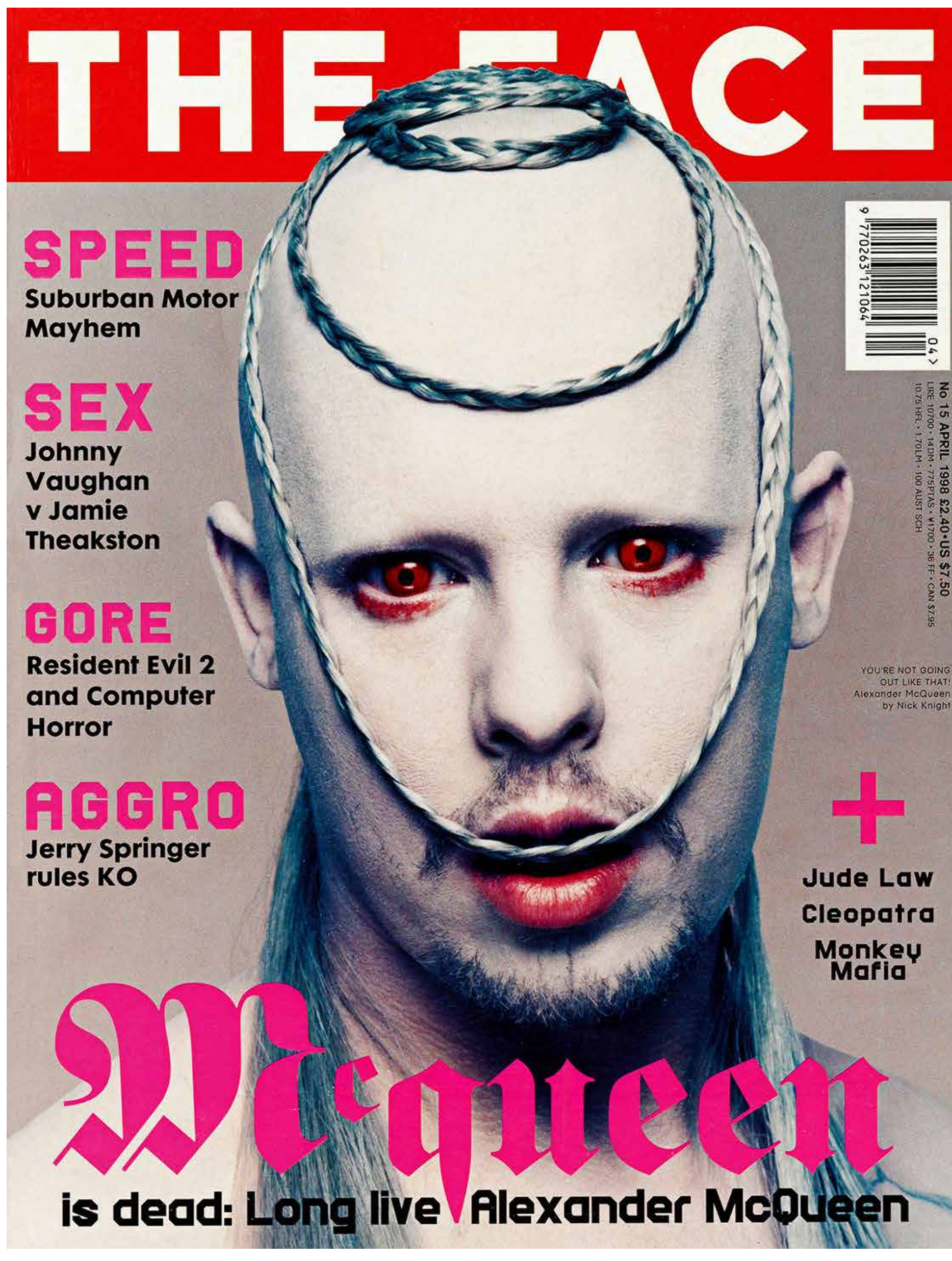

ALÉCIO ROSSI FLLHO 165 

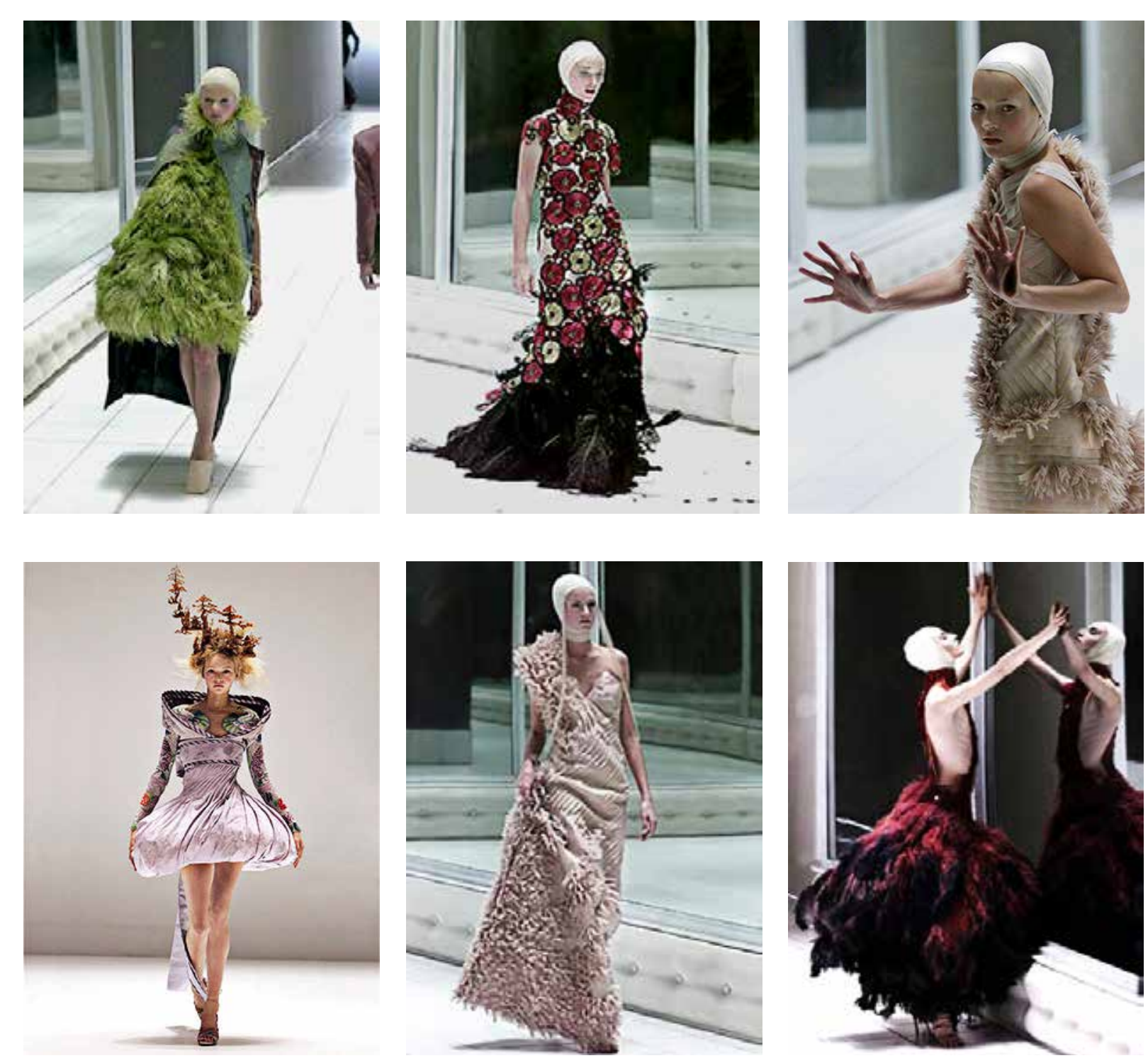

similares aos utilizados em hospitais para fazer curativos. Os materiais estariam longe dos convencionais: conchas, plumas, ossos, ostras, pássaros, galhos, plásticos. Naturais e artificiais, combinam-se e emolduram silhuetas alongadas, fazem barulho ao caminhar e movimentar-se. No centro do salão/vitrine/cenário há uma grande caixa de vidro translúcido e sujo que simula um aquário mal cuidado. Dentro dele pode-se ver pequenos vultos em movimento. Ao final do desflie, público, imprensa e fotógrafos veêm atônitos as paredes desta caixa central abrirem-se, e se quebrarem ao cair no chão. De dentro dela saem borboletas voando. Ao centro, recostada em uma chaise longue feita de rendas e chifres, numa referência à
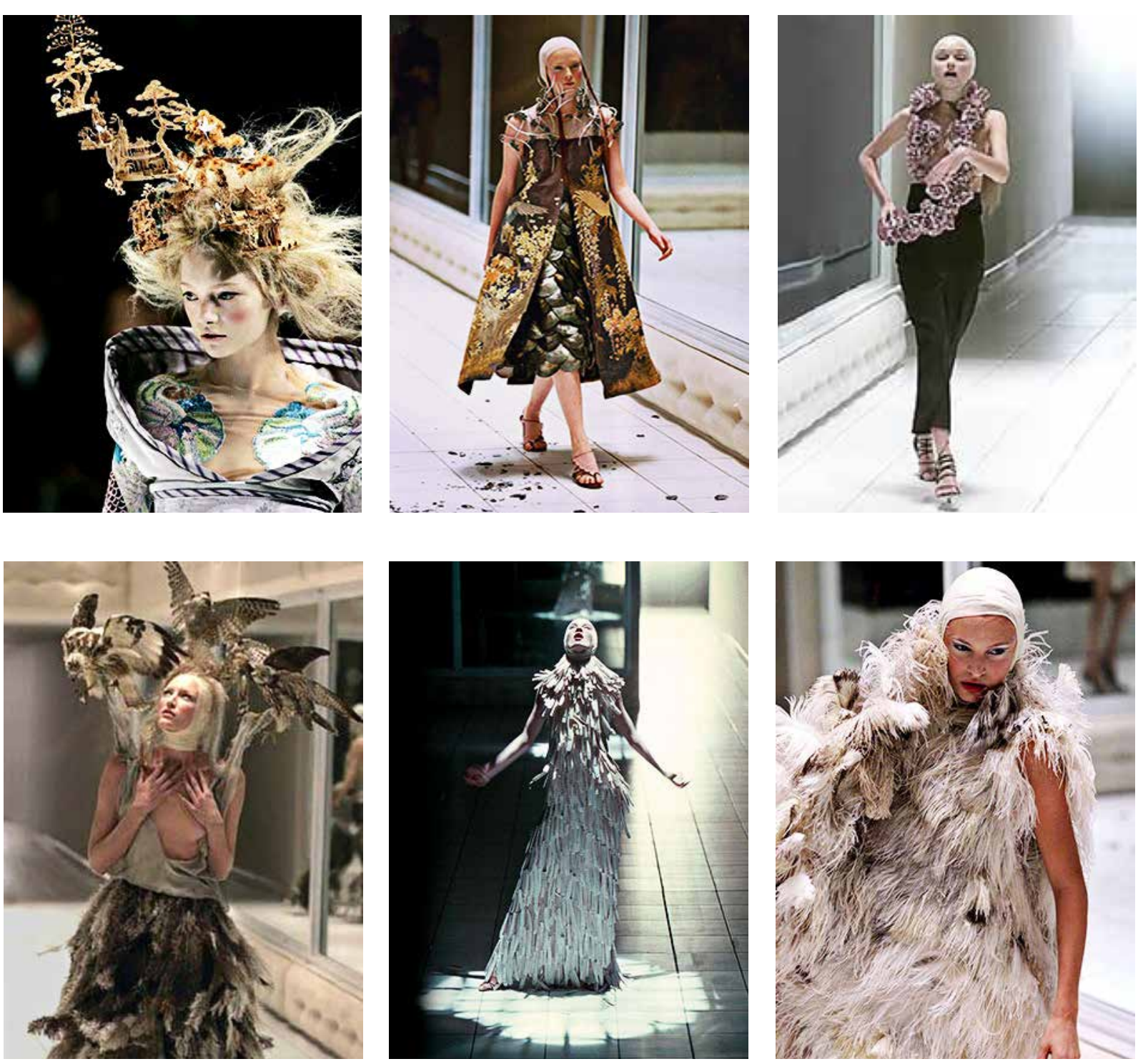

pose clássica de Botticelli, há uma mulher obesa conectada a tubos transparentes de onde fluem líquidos. A imagem também faz referência ao fotógrafo norte americano Joel Peter Witkin, ou configura-se mesmo como uma citação direta de seu trabalho.

As imagens instigantes de Witkin reproduzem fotografias antigas e desgastadas. O tema recorrente é o do estranho, do grotesco, do bizarro. Pessoas com alguma deformação congênita, ou amputadas, transexuais, travestis e transgêneros são presenças constantes. Assim como a presença da morte e da decomposição e o estranhamento provocado ao compor as cenas, planejadas e manipuladas para registar uma intencionalidade de
Alexander McQueen Voss, Spring/Summer 200 http:///savagebeauty 作 
verossimelhança do artista. As fotografias são desgastadas por processos mecânicos e químicos para que pareçam envelhecidas e verdadeiras. Uma simulação de registros bizarros e de teatro de horror que explicita a dor e o sofrimento humanos. As cenas planejadas retratam seres marginalizados e excluídos. Witkin busca a beleza no estranhamento, no raro e incomum, mas também na dor e no descompasso entre o homem e o mundo.

Em 1997, McQueen criou o que chamou de primitivismo na modelagem e nos materiais. A coleção, fotografada por Nick Knight, trouxe a deformação do corpo e o estranhamento como reveladores de fugir e de questionar os padrões.

É possível estabelecer uma comparação entre o que diz Pallasmaa (2011) sobre as edificações de Alvar Aalto e o trabalho de McQueen:

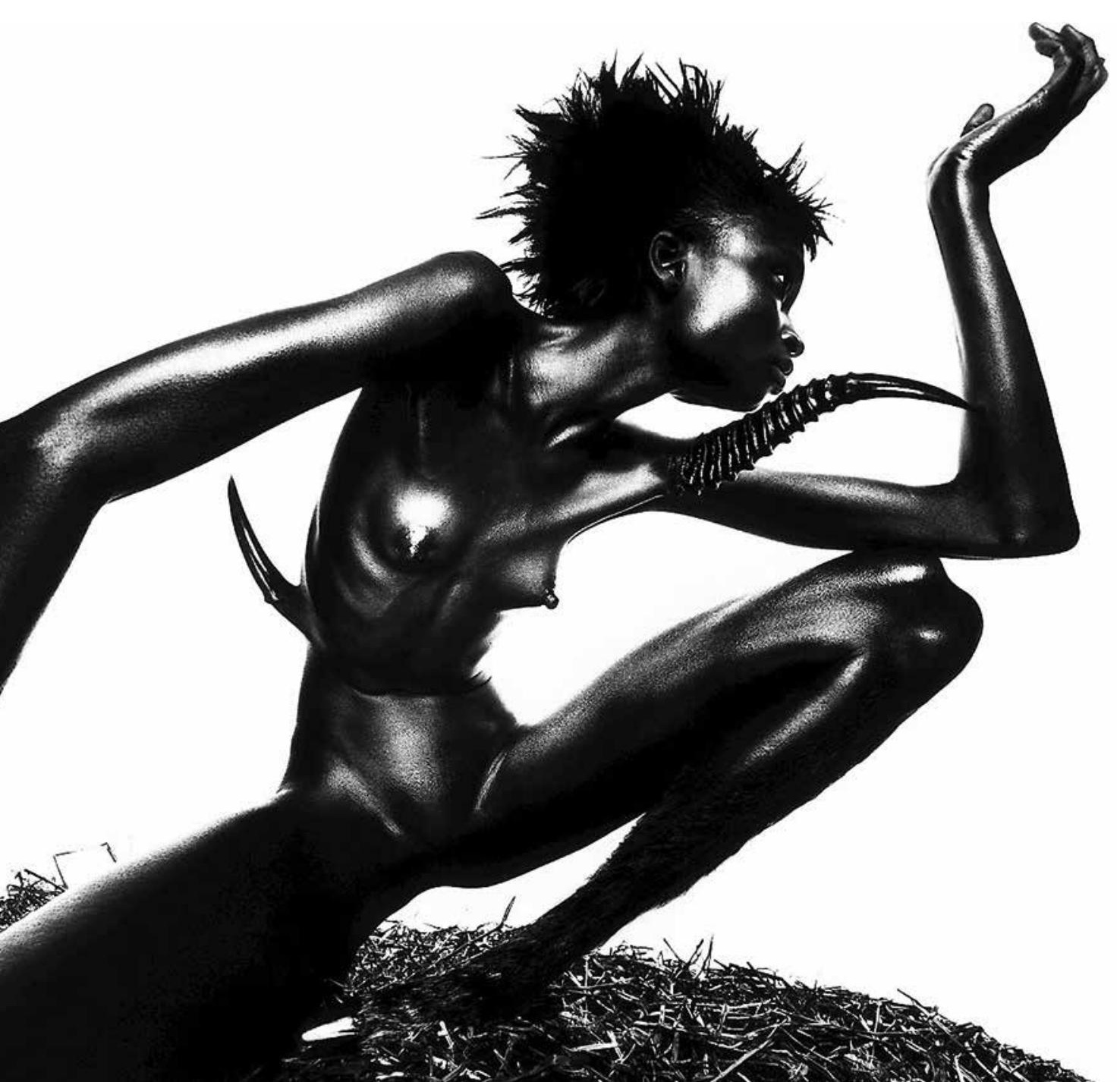

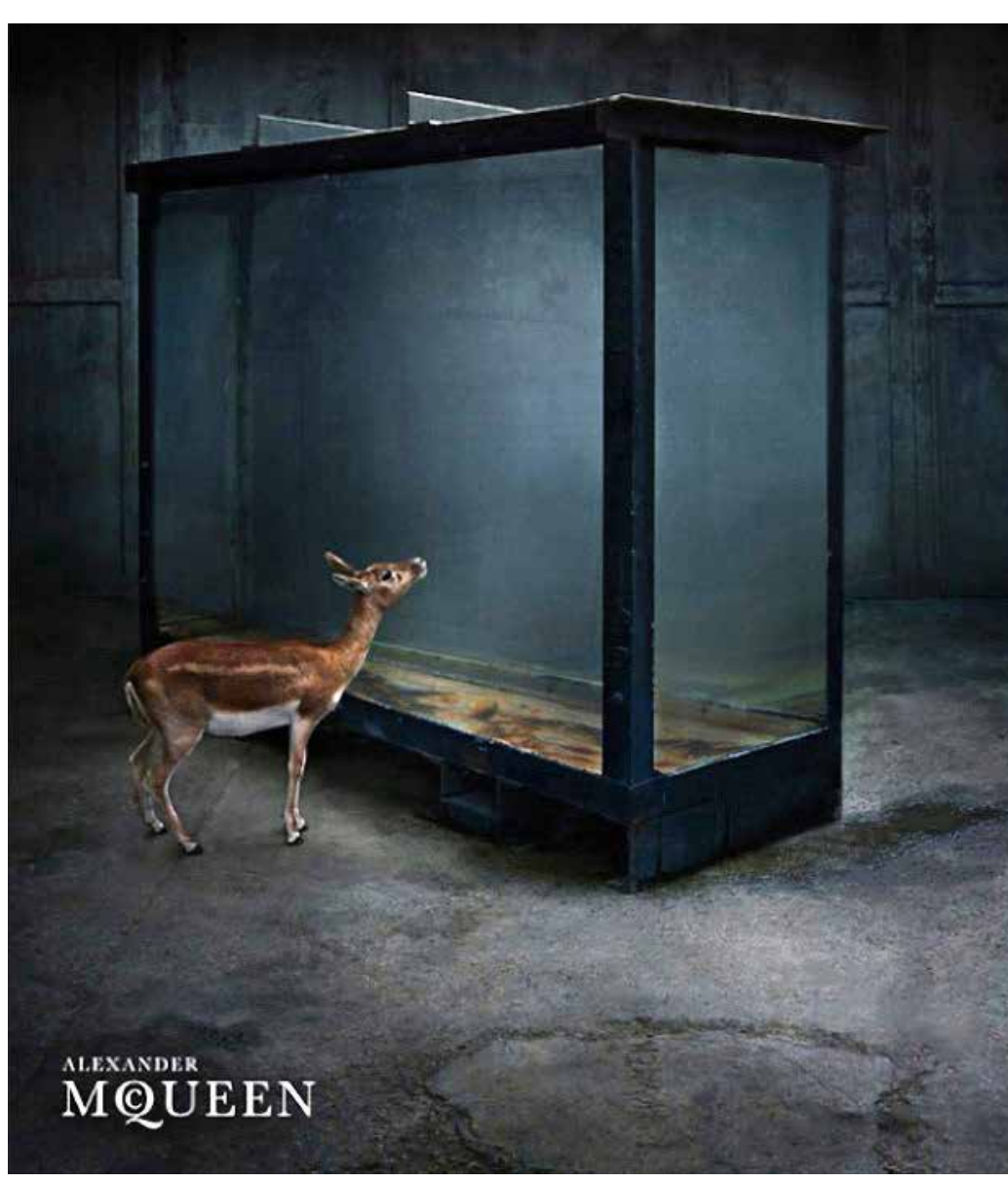

"It is important to look at death because it is a part of life. It is a sad thing, melancholic but romantic at the same time. It is the end of a cycle - everything has to end. The cycle of life is positive because it gives room for new things."

Alexander McQueen

É importante olhar para o morte, pois ela é parte da vida. É triste e melancólico, mas romântico ao mesmo tempo. É o fim de um ciclo tudo tem um fim. O ciclo do vida é positivo, pois possibi-

"Elas às vezes até parecem deselegantes e mal resolvidas lita coisas novas. como desenhos, mas são concebidas para serem apreciadas em seu encontro físico e espacial real, 'na carne' do mun- Savage Beauty, p.74 do vivo, não como construções de uma visão idealizada." (2011, p 67)

Para McQueen, o corpo é campo de experimentapor ele desenvolvidas a cada coleção são complexas e Fotpanhapublitaria estruturadas sob questionamentos do fazer moda e suas relações contextuais.

A mulher não é suporte para as vestimentas e estas não são criadas para proteger o corpo. Peças e acessórios expressam o desejo de colocar-se no mundo e de dar a ele significado. mpanha pub

hitp://savagebeauty.alexandermcqueen.com/ hitp: ://savagebeauty.lalex
Acesso em 21 janeiro 2018

À esquerda Alexander McQueen, 1998 Ftografia de Nick Knight para material e coleção hitp://wwww.nickknight.com/ gráfico utilizado em lançamento 


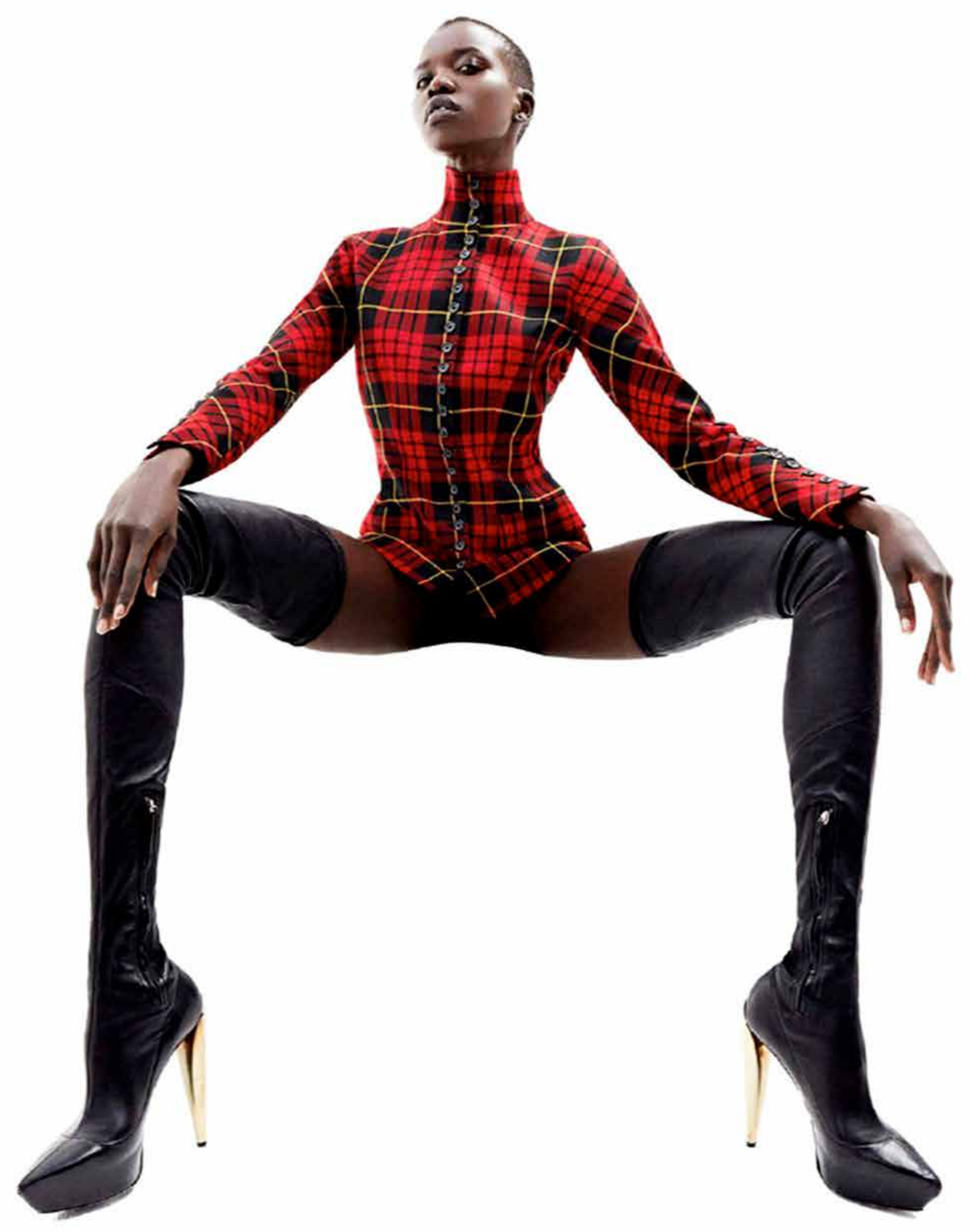

\section{Low tech hight tech Artesania, arte e design}

Da artesania presente na alfaiataria onde iniciou seus trabalhos até o holagrama que projetou a modelo Kate Moss em seu desfile de 2006, a tecnologia está presente entre os suportes de pesquisa de McQueen. O fazer e o pensar com a tecnologia vão além das atividades de proAlexander McQueen Tpressão das raizes escocesas, oxadrez quase uma assinatura de McQueen hitp://www.independent.co.uk/life-style/ fashion/teatures/origin-of-a-man-the-ba/

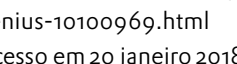
dução textil. Seu trabalho chamado de No.13 de 1999 foi apresentado com uma modelo no centro de uma plataforma de madeira entre dois robôs semelhantes aos utilizados na indústria automobilística que, comandados por programação, pintaram o vestido com jatos de tinta. A performance da modelo, num misto de medo e surpresa, se assemelha a de uma atriz em espetáculo teatral. A dramaticidade é recurso recorrente em suas apresentações e desfiles. As entradas e performances das modelos são orquestradas por roteiro planejado com precisão. 

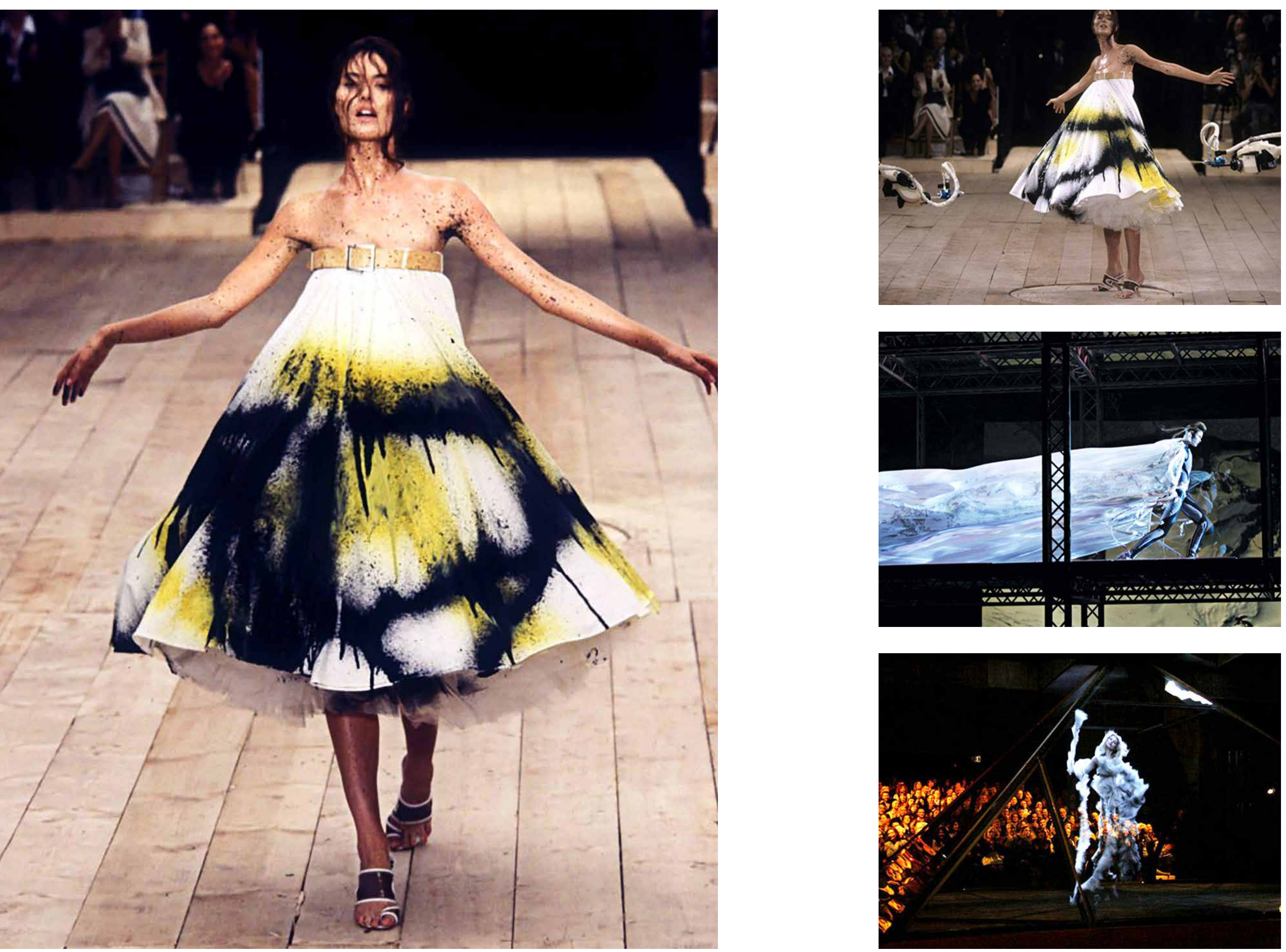

"I want empower women.

I want people to be afraid of the women I dress"

Alexander McQueen

Eu quero empoderar as mu-

Iheres. Quero que as pessoas

tenham medo das mulheres

que eu visto.

Tradução livre

Savage Beauty, p. 74

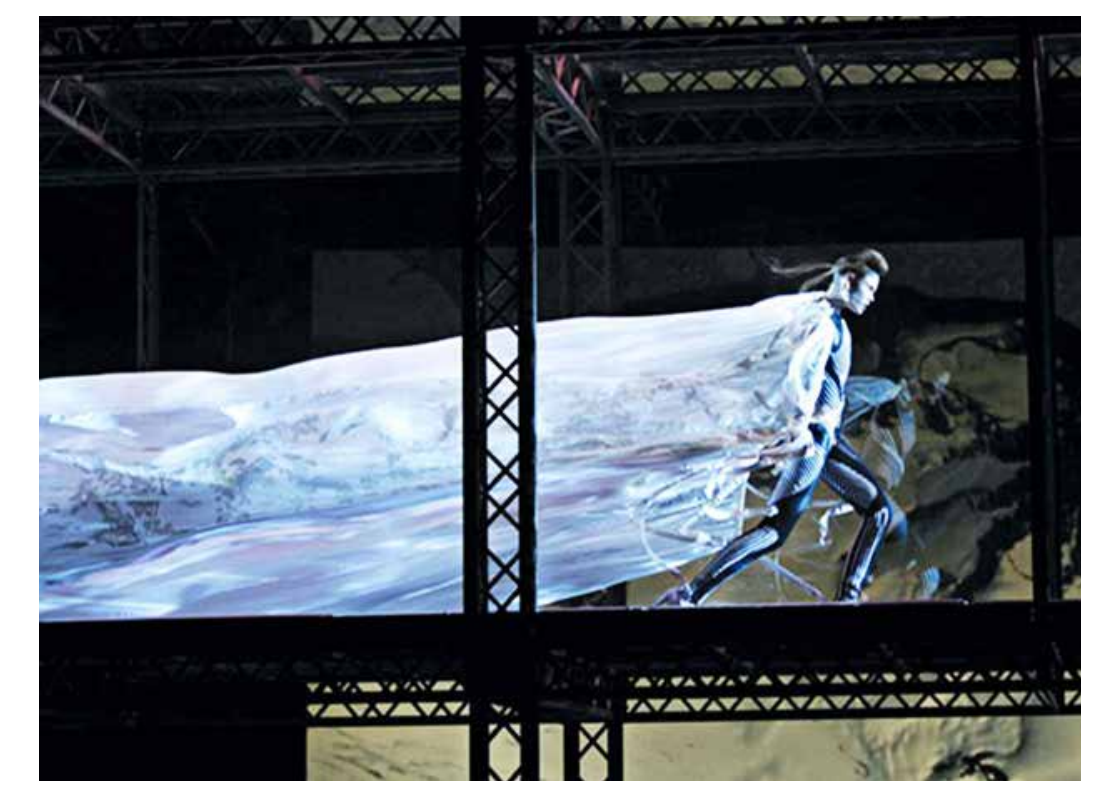

Alexander McQuee

Finale at No. 13

Prografia de Chris Moore

Acesso em 211 janeiro 2018

Scanners

Autumn/Winter 2003
Fotografia de Chris Moore

A

Kate Moss

Holograma

https://thestylefactoryblog.wordpress.com/

tag/alexander-mcqueen/
Acesso em 21 janeiro 2018

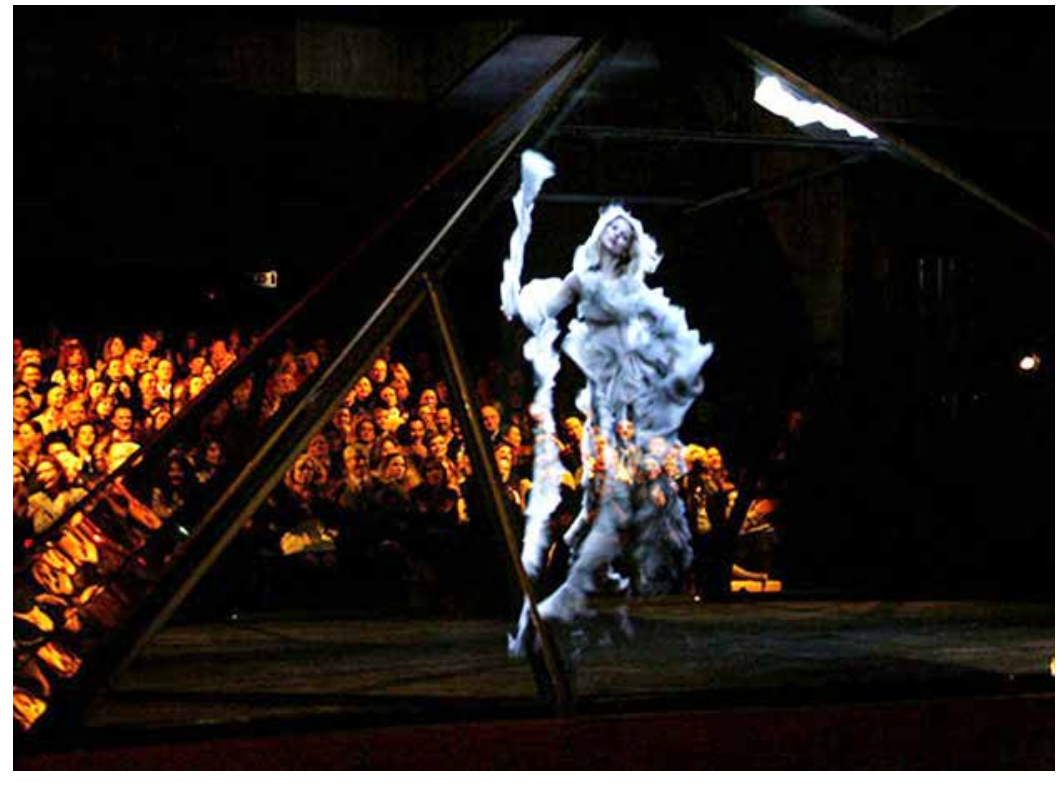



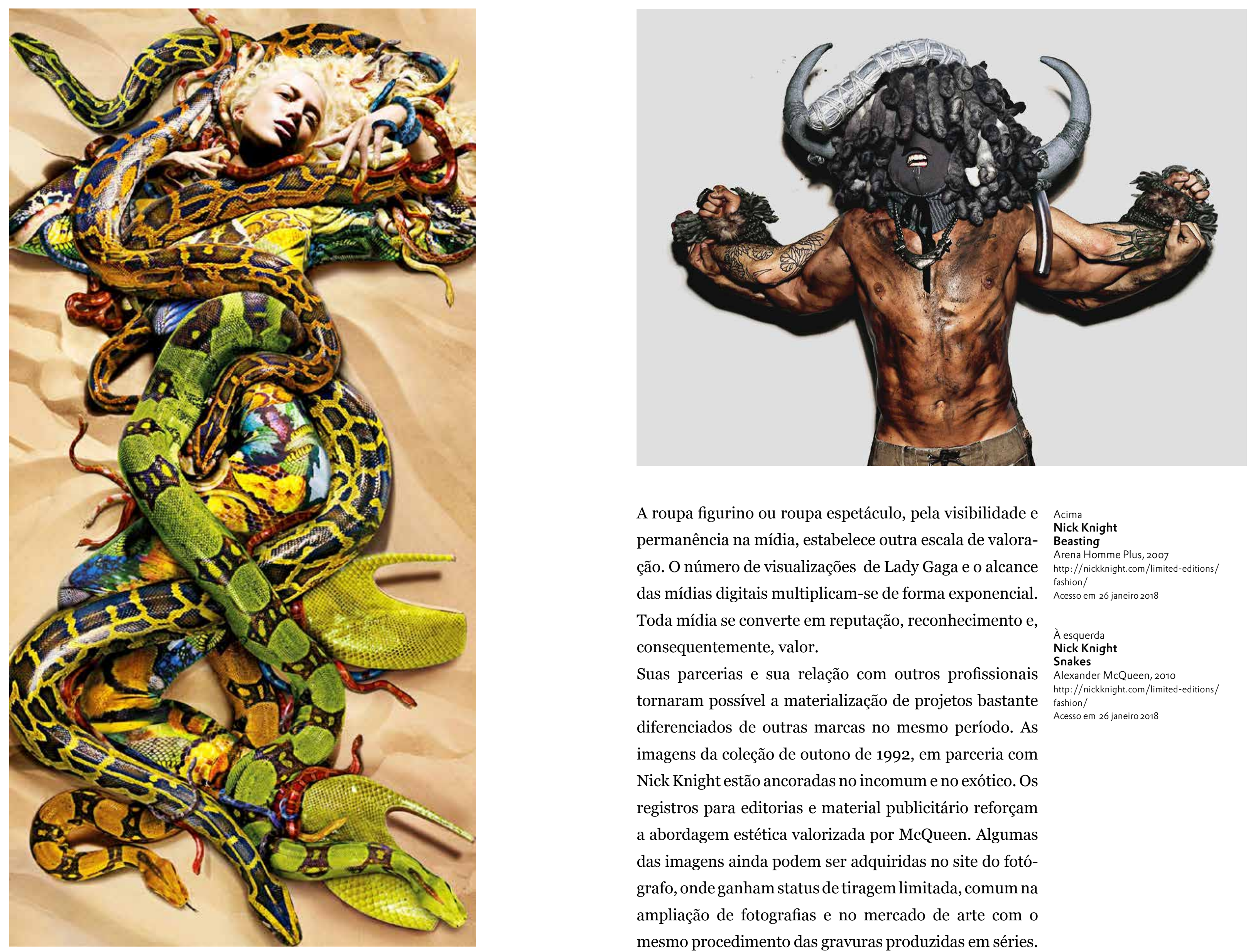

A roupa figurino ou roupa espetáculo, pela visibilidade e permanência na mídia, estabelece outra escala de valoração. O número de visualizações de Lady Gaga e o alcance das mídias digitais multiplicam-se de forma exponencial. Toda mídia se converte em reputação, reconhecimento e, consequentemente, valor.

Suas parcerias e sua relação com outros profissionais tornaram possível a materialização de projetos bastante diferenciados de outras marcas no mesmo período. As Acima
Nick Knight Beasting Arena Homme Plus, 2007 http://nicknnight.com/limited-editions/ Acesso em 26 janeiro 2018 À esquerda
Nick Knight
Snakes Alexander McQueen, 2010 htp://nicknnight.com/limited-editions/ fashion/ Acesso em 26 janeiro 2018 imagens da coleção de outono de 1992, em parceria com Nick Knight estão ancoradas no incomum e no exótico. Os registros para editorias e material publicitário reforçam a abordagem estética valorizada por McQueen. Algumas das imagens ainda podem ser adquiridas no site do fotógrafo, onde ganham status de tiragem limitada, comum na ampliação de fotografias e no mercado de arte com o mesmo procedimento das gravuras produzidas em séries. 


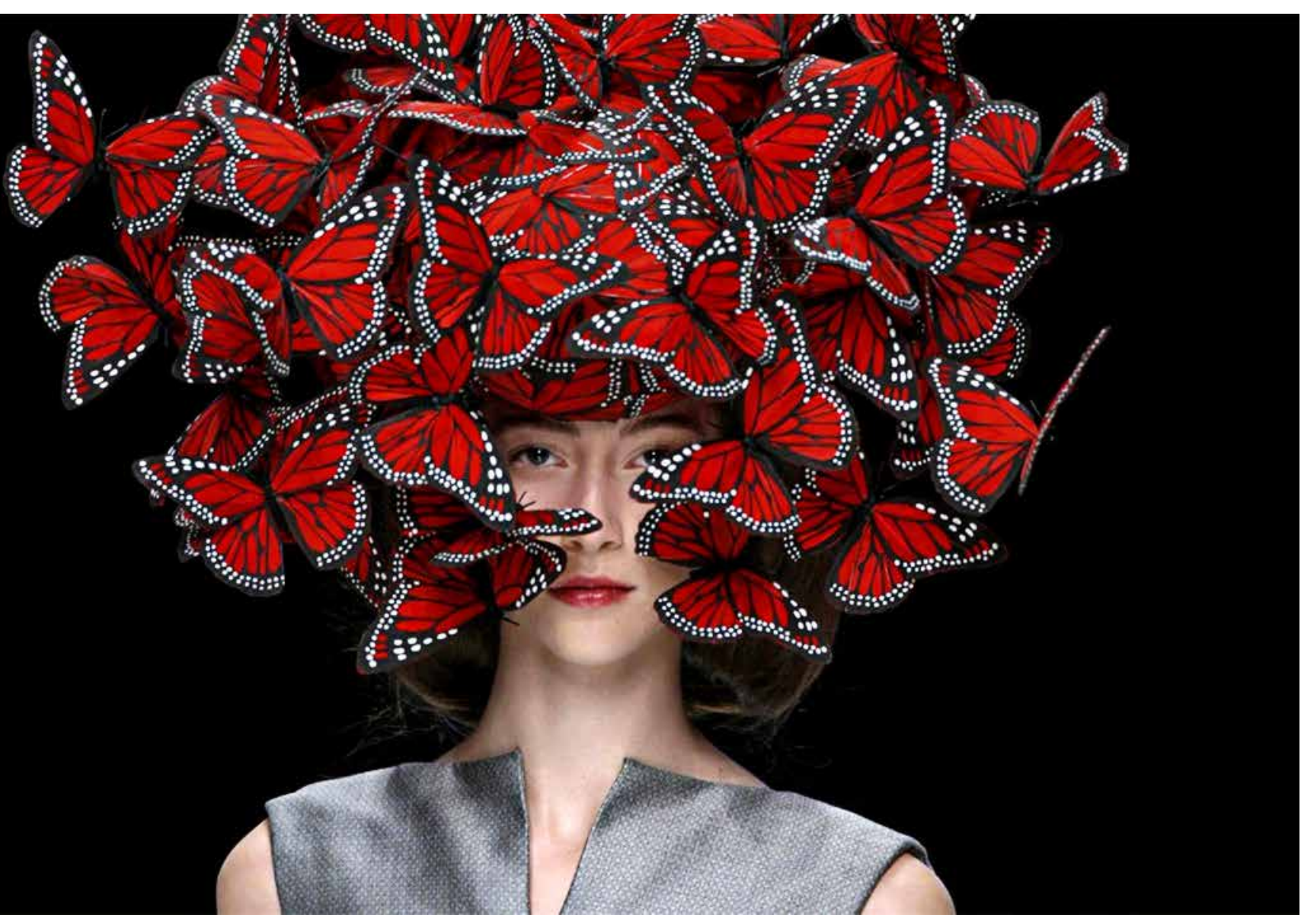

Acima Outro parceiro importante foi o ourives Shaun Leane. Alexander McQueen e Juntos criaram peças que se tornaram ícones nas passaButterfly, Headdress, 2008

blog/2015/02/20/savage-beauty-at-the-va-e-

Acesso em 26 janeiro 20 À direita
Alexander McQueen, à roupa de forma indissociável. O adorno incorpora-se ao

relas e hoje pertencem a museus. Os adornos e acessórios desenvolvidos por Leane em metais e outros materiais muitas vezes tomam a proporção do corpo e integram-se traje e a composição ganha aspectos dramáticos e cênihttp: //nickknight.co Acesso em 26 janeiro 2018 pectuam-se entre design, arte e joias. Philip Treacy, provavelmente o mais famoso criador de chapéus e acessórios, viu seu trabalho criativo ganhar forte tom dramático ao aproximar-se de McQueen. Objetos e seres empalhados, flores, galhos, plástico e latas amassadas são utilizados em composições inusitadas com feltros, arames, tecidos e telas, materiais mais tradicionais da artesania de fazer chapéus.

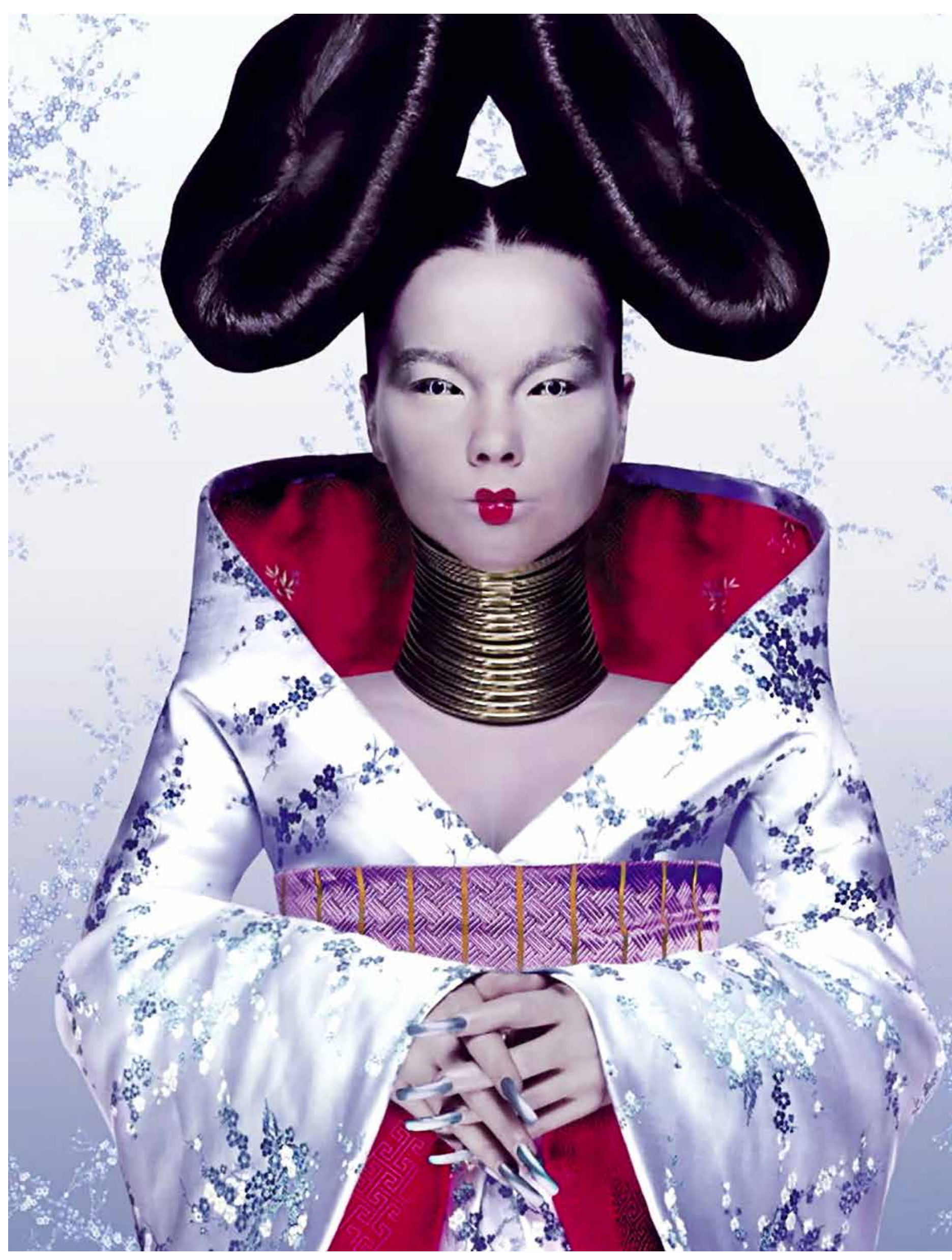



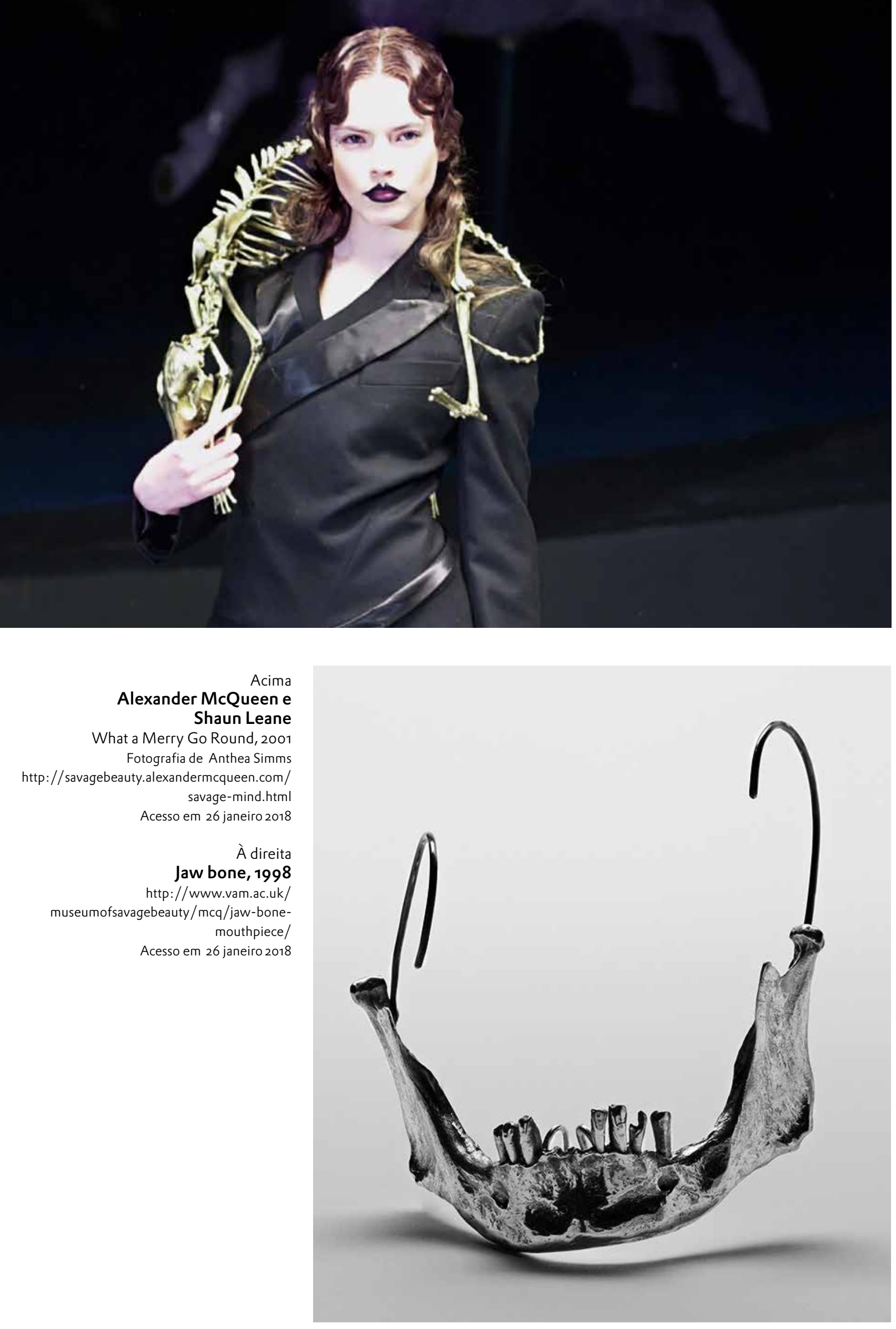

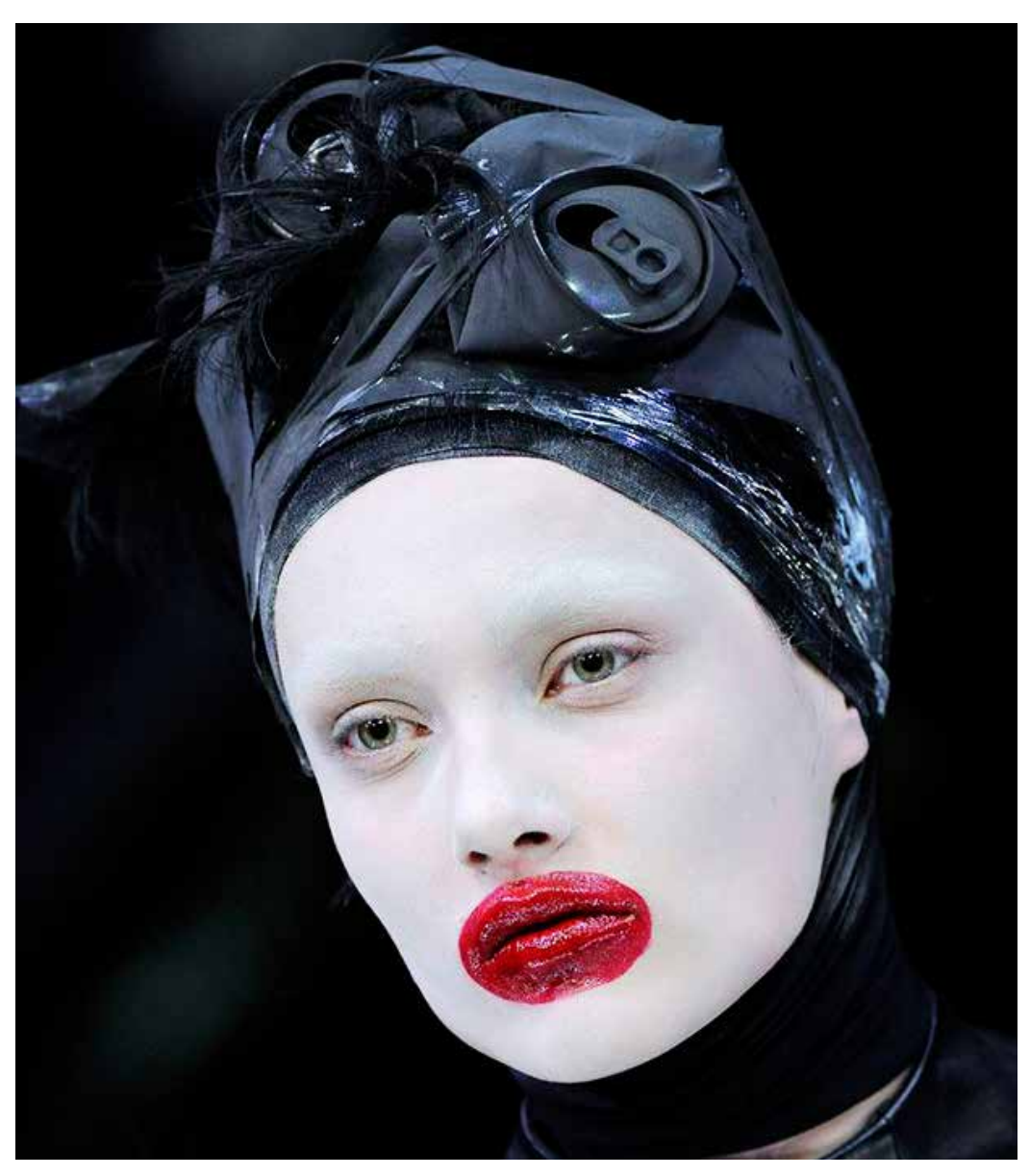

Alexander McQueen e

Outono, 2009

https://www.vogue.com/fashion-shows/

fall-20og-ready-to-wear/alexander-mcqueen/

Acesso em 26 janeiro 2018

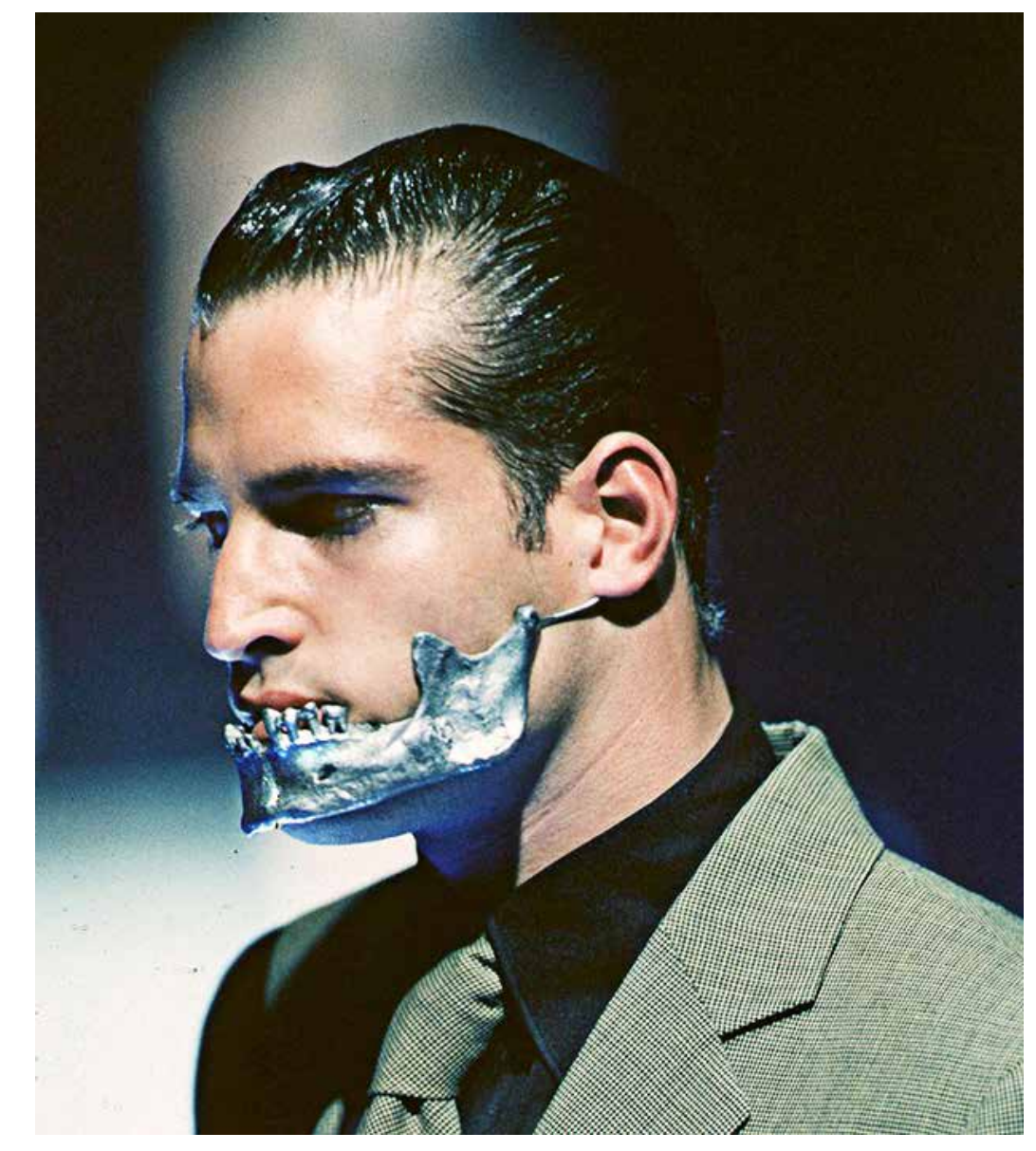

Alexander McQueen

Shaun Leane

http://www.vam.ac.uly/

museumofsavagebeauty/rel/on-the-catwalk-

Acesso em 26 janeiro 2018 


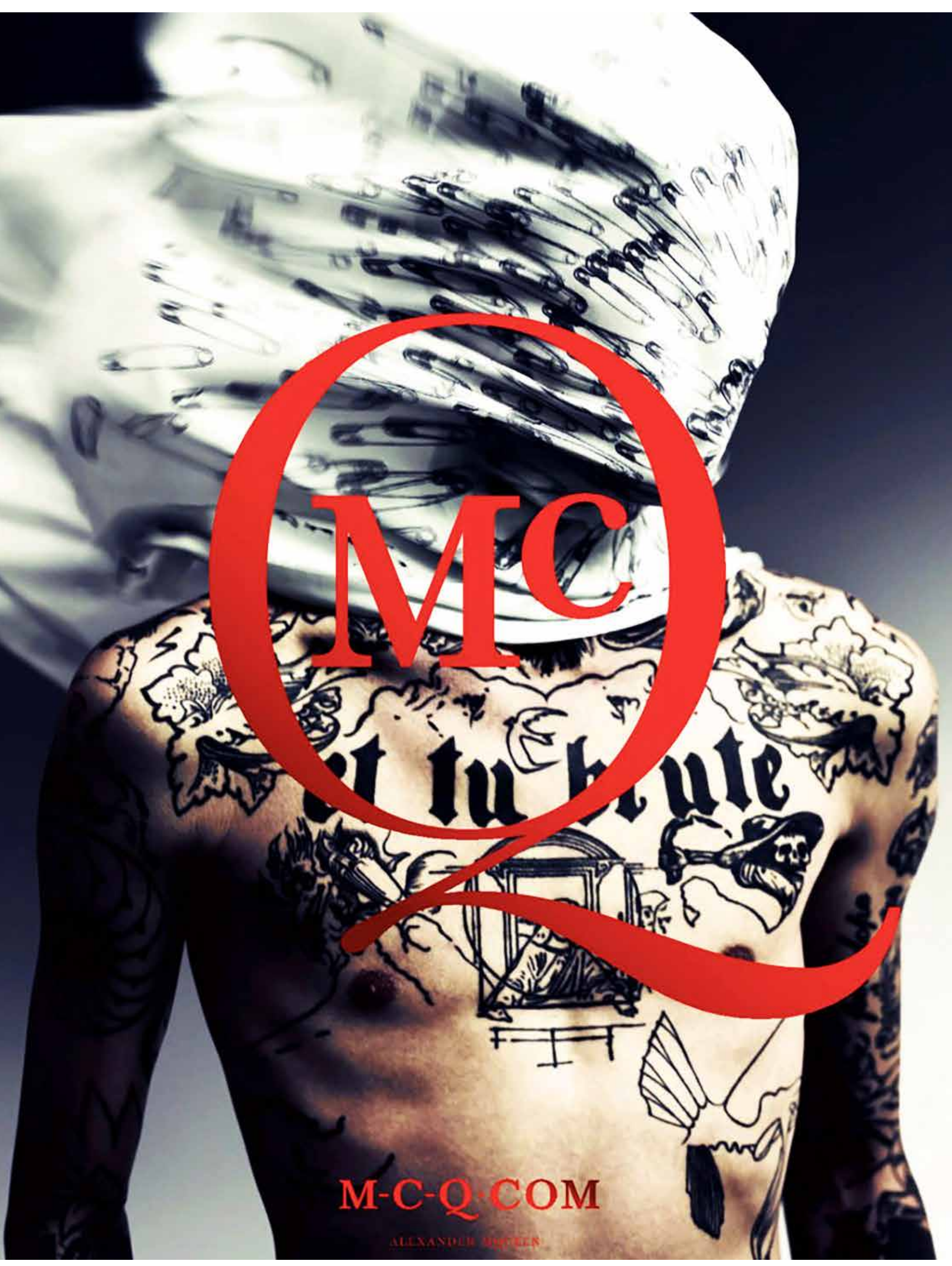

A parceria resultou em chapéus, adereços e complementos grandes e exuberantes que funcionaram como objetos cênicos de alto impacto no público e na mídia.

A visibilidade destas peças, muitas delas utilizadas por artistas e celebridades que inundam as plataformas digitais e as mídias convencionais, fortalecem a marca Alexander Mcqueen, além da imagem pública do criador. As parcerias e atividades desenvolvidas por McQueen com fornecedores e outros profissionais renomados em diferentes frentes de atuação, mais do que uma estratégia de posicionamento de marca, se assemelha ao processo criativo de muitos artistas e designers. Estes lançam mão de seu repertório, de sua história, de seus referenciais no desenvolvimento de seus trabalhos. Os procedimentos para a criação e apresentação de novas coleções para McQueen foram além da atitude de resolver um problema de vestuário, comum ao pensamento do design. As criações de McQueen expressam e constróem identidade, instigando a pensar e sentir além do vestuário.

Iexander-mcqueen-2009/ $/ 10 / \mathrm{mcq}$

A cada coleção, as abordagens ganharam contorno de arte, fazendo pensar sobre como romper padrões do corpo, resgatando o olhar para a atribuição de valor de coisas naturais ou quando apontaram para a força selvagem e para o primitivismo inerente ao convívio humano. O que se discutia era o poder da mulher, da religião, da diversidade de culturas e de comportamentos entre outros temas, misturando uma certa utopia à realidade. Desde 2000, quando foi adquirida pela empresa Gucci, a marca Alexander McQueen continua com público fiel, mesmo depois da morte trágica do designer, que cometeu suicídio em fevereiro de 2010, uma semana após a morte de sua mãe. A marca mantém Sarah Burton como diretora criativa desde então e conta com 57 lojas em 20 países. Além de vendas on-line em plataforma própria. 


\section{Design e Arte \\ Estratégias de persuasão \\ Considerações finais}

As redes sociais e os mecanismos de comunicação digital modificam a forma de se ver e conhecer a realidade, colocando em evidência fatos e acontecimentos de acordo

"Design é só sobre desecom lógicas e estratégias pautadas na construção de , mas este desejo parece estranhamente quase sem imagens públicas de celebridades, marcas e produtos. O estímulo ao consumo desconsidera o desgaste de bens naturais e, segundo Georgescu-Roegen, leva a situações irreversíveis. A entropia é o resultado imediato do que ele chama de "alegria de viver", (2012, p. 62) reflexo do consumismo e das desigualdades de qualidade de vida que sujeito, ou pelo menos sem carência; ou seja, o design parece propor um novo tipo de narcisismo que é todo imagem e nenhuma interioidade - uma apoteose do se afirma pelo consumismo. Para ele, os recursos do pla- é sua desaparição potencial." neta não permitem o mesmo nível de qualidade de vida FOSTER, 2011, p. 57 para todos. Com certa ironia, afirma que esse desequilíbrio entre produção e consumo nos leva a uma perda irreparável de energia. 
Sob o ponto de vista de comunicação, a entropia relaciona-se a uma desorganização do sistema. Refere-se a transformação das informações, na medida da quantidade de incerteza e do novo. A dificuldade de validar e reconhecer a informação coloca em questão a verdade e a verossimilhança. Não somente pelo que pode ser previsível, pelos recursos de estatísticas e análises de tendência de comportamento, mas pela possibilidade de emergência de acontecimentos não previstos, reais ou inventados. A comunicação digital e as diferentes mídias acabam por constituir um ambiente onde não há mais diferença entre realidade e ficção. Uma se transforma na outra e leva a um estado de ânimo em que o que interessa é a visibilidade proporcionada pela capacidade de produzir e disseminar imagens através dos dispositivos midiáticos.

Celebridades e pessoas comuns são estimuladas a compartilhar suas experiências pessoais em tempo real. As stories, pelo caráter imediato da publicação on-line, apontam para a credibilidade dos fatos ou ao menos para sua verossimilhança. Essa produção de imagens, baseada na conexão e na disseminação, é resultado da busca de indivíduos por outros tantos, como se todos estivessem sobre uma fita de Moebius em que o dentro se confunde com o fora. Quem segue quer ser seguido. Esse é o acordo. O consumo simbólico de estilos de vida, semelhantes em aparência e exibidos na superfície da tela, a rigor enfraquecem as diferenças e deixam de ser plurais para se tornarem semelhantes. Não são mais estilos de vida, são representações e simulações de um único modo de viver no qual impera a beleza, a felicidade e o sucesso. Nesse contexto, o sujeito desaparece e, em escala, o que se vê são desejos voltados a um ideal único: se sentir parte de um mundo sem dor, sem esforço e sem sofrimento.

Ao entender o consumo como forma de construção de individualidade, na produção em escala, o sujeito desaparece.
No entanto, a tecnologia permite que a produção em alta escala simule a produção de produtos personalizados, quando, por exemplo, a Gucci sobrepõe ao bordado da marca uma inscrição que se parece com uma pichação. O caráter de exclusividade e as tiragens limitadas geram maior valor e maior consumo. Desejos de consumo se mesclam também ao desejo de ser visto, reconhecido, desejado. A possibilidade de gerar conteúdo para as plataformas digitais faz com que ocorra uma redução nos espaços entre produção e consumo, entende-se consumo não só a aquisição física do produto, mas o consumo de imagem e o fluxo de consumo digital. O impacto das imagens digitais é potente, mas simplifica a percepção de consumo e descarte possibilitando que se naturalize ou se acentue a geração de resíduos. Faz parte da naturalização a construção dessa espécie de hegemonia no modo como se constrói a imagem no ambiente digital que lida com mudanças constantes, com o descarte acelerado e com o estímulo a se seguir tendências que se universalizam muito rapidamente. Ainda, segundo Georgescu-Roegen, "tudo o que a indústria produz é resíduo", inclusive o produto e estamos sempre em déficit. (2012, p.62)

\section{Pós-produção}

A criação no design e na arte sempre estará vinculada à "Usar um objeto é, necessariahistória e ao contexto do designer ou artista. Cada obra mente, interpretó-lo. Utilizar ou produto será resultado do repertório do criador e umproduto é, às vezes, trair uma resposta a um questionamento interno/externo. seus conceitos; o ato de ler, Para a arte, a motivação pode ter um caráter mais filosó de olhar uma obra de arte ou fico- $O$ que fazemos aqui? O que nos mobiliza? O que de assistir a um filme significo significa isso? - podendo resultar em processos e na também saber contorná-los: o imaterialidade, não necessariamente em obras perma- uso é um ato de micropiratario nentes. O caráter efêmero da obra, muitas vezes, é seu o grau zero da pós-produção. ponto forte. BOURRIAUD, 2008, P. 21 
Para o design os projetos podem responder a um outro tipo de estímulo externo - Para que serve? Como funciona? Como resolver dado problema? Como criar uma necessidade de consumo? Como se faz? Como melhorar atividades humanas? - resultando em objetos e processos com função e uso pré-estabelecidos. No entanto, as fronteiras entre arte e design são difusas e talvez devêssemos pensar na lógica de sobreposição entre essas áreas de conhecimento. Artistas realizam projetos que poderiam ser multiplicados industrialmente e designers produzem objetos sem que se estabeleçam para eles uma função única ou específica.

Num exercício de metalinguagem, arte relaciona-se com “o que?" se faz buscando dar sentido a partir de posicionamento político e ideológico da produção/obra. O trabalho do artista precisa ser validado e reconhecido institucionalmente e os espaços culturais desempenham esse papel. Curadores e diretores legitimam a produção artística e, direta ou indiretamente, participam da atribuição de valor das obras. O mercado acata.

O design atende a demanda de produção e consumo. Relaciona-se de forma mais direta com o mercado A validação e o reconhecimento no design se estabelecem geralmente pela produção em escala. $\mathrm{O}$ volume de vendas determina o sucesso do produto.

A indústria da moda tem se apropriado de obras e procedimentos de artistas como estratégia de atribuir maior valor ao que é desenvolvido em escala. A obra, ou parte dela, se dilui e se multiplica em produtos diversos em busca de dar a estes o caráter de produção limitada e exclusiva. A marca Louis Vuitton associa-se a diferentes profissionais, artistas, fotógrafos, arquitetos, designers de forma a fazer seu público percebê-la como valor resultante de uma produção cultural própria.
Contemporaneamente parece quase impossível a criação de algo realmente novo, o que faz com que misturas e combinatórias, reprocessamentos, mudança de contextos e, às vezes, formas de produção, sejam vistos como procedimentos comuns.

No livro Appropriation organizado por David Evans (2009), diferentes autores tratam a mixagem como meio de produção da arte contemporânea e talvez se deva estender esta discussão ao design. Os deslocamentos de contextos de tempo e espaço atualizam ou ressignificam objetos e produtos. É inegável reconhecer o design como parte da produção cultural ligada ao comportamento contemporâneo do mundo artificial construído e em processo. A produção cultural desdobra-se entre os acontecimen tos reais e imaginados, seu público imediato e os registros dela decorrentes. A permanência dos registros audio-visuais na mídia também resulta em obra e resíduo este entendido como menos relevantes: ruídos; misturas entre obra e vida cotidiana e privada; restos de edição; notícias; comentários em blogs e outras plataformas digitais. Muitas vezes essa produção paralela atinge um número maior de audiência do que o produzido em plataformas oficiais e institucionalizadas.

Há ainda que se distinguir a produção cultural entre registro e obra. Em época de pós-produção (BOURRIAUD, 2008) e apropriação (EVANS, 2009), na produção artística efêmera, tal como performance ou obra efêmera propriamente dita, o acontecimento situado no tempo e no espaço deixa de existir. O que resta, além da fruição e da memória do público que se relacionou efetivamente com a obra, são os seus registros audiovisuais. Em alguns casos são estes que entram para o mercado da arte e se envolvem com o caráter de obra, embora sejam documentos históricos. Assim, grandes museus possuem acervos fotográficos e audiovisuais que resultam 
de acontecimentos artísticos específicos. Esses arquivos com caráter documental muitas vezes são utilizados em retrospectivas e na reconstituição de obras. Em outros casos, no entanto, a fotografia e o audiovisual são concebidos pelos próprios artistas.

O resíduo digital propaga-se sem distinção nas redes. Com isso o papel de curadoria tornou-se contemporaneamente mais importante. A que recorte deve-se dar atenção? Quais os agrupamentos possíveis e qual o significado de cada agrupamento? Como classificar? Com que critérios se estabelece uma taxonomia possível? A serviço de quem? Curadoria e edição no universo digital podem ser um problema, quando não é fácil saber quais critérios as embasam.

\section{"O olho é o órgão da dis- O corpo e a cidade}

tância e da separação,

enquanto o tato é o sentido $\mathrm{O}$ olhar consome e amplia o desejo. $\mathrm{O}$ consumo gera o da proximidade, intimidade fluxo econômico e auxilia na construção de identidades. e afeição. O olho analisa, Vestir-se, compor um estilo com roupas e adereços, conscontrola e investiga, titui-se cada vez mais como linguagem e dita regras de peroo passo que o toque tencimento não somente a determinados grupos e classes aproxima e acaricia. sociais, mas tem força também para simular uma espécie PALLASMAA, 2011, P.43 de elo de caráter estético entre o que é próprio a um mercado de luxo e o que de algum modo o desafia.

A disponibilização de informações, novas temporadas, novas coleções desestruturam as fronteiras geográficas e políticas. A organização sazonal já não faz tanto sentido. Primavera, verão, outono e inverno, antes determinantes para a escolha de materiais e tendências, já não importam para o consumo global online. Vintage ou futurista, perto ou longe, as relações de tempo e espaço se reorganizam em torno da criação, produção e consumo. A percepção do corpo e do consumo como instrumentos econômicos e políticos contribuem de forma a constituir o reposicionamento de artistas e designers, resgatando valores e significados renegados pela grande indústria da moda. Neste sentido, o trabalho de Alexander McQueen fez com que o corpo voltasse a ser resistência. A desobediência de padrões e sistemas, ainda que pertencente ao sistema, fez com que o trabalho do designer inglês tenha sido reconhecido pela quebra de fronteiras entre arte e design. Por isso, tão longevo e duradouro, por isso sua obra/produto pertence a coleções e museus. O impacto de seu trabalho vai além de seu posicionamento estético, estimulando a mudança de percepção. É um designer com claro posicionamento social e político, não como um provocador superficial e midiático, mas, a partir de seu trabalho, propôs a mistura de desfile e performance artística. Sua produção, resultante de seu repertório e de sua aproximação com outros profissionais criativos, estimula a fantasia e o deleite, colocando em discussão as fronteiras do corpo, a ruptura e a quebra de padrões.

$\mathrm{O}$ registro de suas performances, assim como os objetos desenvolvidos por ele, também fazem parte de sua produção. Essas imagens se desdobram com força para influenciar outros designers e artistas contemporâneos.

Nas cidades, o fluxo acelerado e os deslocamentos dificultam as relações e aproximações entre as pessoas. O relacionamento presencial gradualmente dálugar às redes sociais. No relacionamento mediado pela tecnologia a imagem digital do selfie é hoje o espelho estirado no tempo. Essa imagem reflete, retrata emultiplica, compartilha e distribui o eu idealizado e desejado. O homem contemporâneo reflete-se nos prédios espelhados que barram o olhar da intimidade e da proximidade. A cidade e o consumo colocam-se de forma a fazer oposição ao corpo, ao coletivo e à diversidade. As grandes cidades, como planejadas hoje, quase sempre estruturam o padrão e desconsideram a construção cultural das relações entre as pessoas. 


\section{Equilíbrio dinâmico}

A tecnologia aplicada à comunicação é a responsável pela aceleração nos modos de ver e viver contemporâneos (ROSA, 2017). A troca constante de informações, a quebra de fronteiras e a ubiquidade dos sistemas digitais descentralizaram a geração de informação e de conhecimento. Se por um lado, a aceleração pode democratizar a informação, por outro torna necessário estabelecer parâmetros e referenciais de confiança sobre o que é e o que não é verdadeiro. A aceleração contribui ainda para o aumento da ansiedade e da insegurança sobre as possibilidades de saber o que acontece, sobre o que é e o que não é relevante. Essas incertezas fragilizam o tecido social.

Lidar com as mudanças constantes e com a sensação de que tudo é efêmero acaba reforçando o consumo como manifestação concreta que pode fazer as pessoas se sentirem sujeitos. Isso no sentido de reconhecer-se dentro do sistema, reconhecer-se consumidor, quer seja de objetos, ou de informação digital. Em Estética Relacional Bourriaud chega a afirmar que "o que não pode ser comercializado tende a desaparecer." (2009, p. 11). Para ele, a arte aparece como resistência que tenta fortalecer as construções coletivas e os relacionamentos, mediados ou não pela tecnologia.

O consumo da moda, como todos os outros, fortalece uma indústria mundial que movimenta a economia e gera empregos. A produção em escala pode reduzir custos e o bom design otimiza matéria prima e formas de distribuição. O espaço para a produção exclusiva e de segmentos específicos provavelmente sempre existirá. A busca de alternativas que desestabilizam o sistema, ou ao menos a forma de olhar para ele, paradoxalmente pode trazer o equilíbrio dinâmico, sobre as incertezas para o consumo sustentável e consciente.
Neste novo contexto, a posse é menos importante que o uso e o compartilhamento. O serviço é tão necessário quanto as relações pessoais e os vínculos afetivos entre pessoas, cidades e territórios. A diversidade do olhar e do comportamento expresso pelo desejo de compartilhar amplifica as respostas criativas aos desafios destes tempos de incertezas e de desordem, ou talvez fosse melhor afirmar, os desafios de um tempo que finalmente assume a transição como o que lhe é próprio. 
Referências

AGAMBEN, G. O que é o contemporâneo e outros ensaios. Chapecó: Argos, 2009.

ARGAN, G.C. Projeto e Destino. São Paulo: Ática, 2001. BAUDRILLARD, J. A sociedade de consumo. Lisboa: Edições 70, 2014.

BERGER, J. Modos de ver. Rio de Janeiro: Rocco, 1999.

BENJAMIN, W. Obras escolhidas: magia e técnica, arte e política. São Paulo: Brasiliense, 1994.

BIGAL, S. O design e o desenho industrial. São Paulo: Anna Blume, 2001.

BOLTON, A. Alexander McQueen, Savage Beauty. Nova York: The Metropolitan Museum of Art, 2011.

BOUROULLEC, R. \& E. Drawing, Paris: JRP - Ringier, 2012. BOURRIAUD, N. Estética relacional. São Paulo: Martins Fontes, 2009.

. Pós-produção. São Paulo: Martins Fontes, 2009. CASTETS, S. Louis Vuitton. Art, Fashion and Architecture. Nova York: Rizzoli, 2009. 
CAUQUELIN, A. Teorias da arte. São Paulo: Martins Fontes, 2005.

CARAMELLA, E. História da Arte: fundamentos semióticos. Bauru: Edusc, 1998.

CHAMBONNIER, J.M. Connaissance des arts: especial issue. Paris, 2014.

CHARNEY, L. e SCHWARTZ, V. R. O cinema e a invencão da vida moderna. São Paulo: Cosac Naify, 2004.

COMPAGNON, A. Os cinco paradoxos da modernidade.

Belo Horizonte: UFMG, 2003.

DEBORD, G. A sociedade do espetáculo. Rio de Janeiro:

Contraponto, 1997.

DAMÁSIO, A. R. O erro de Descartes. São Paulo: Companhia das Letras, 1996.

DELEUZE, G. Lógica do sentido. São Paulo: Perspectiva| Universidade de São Paulo, 1974.

EVANS, D. Appropriation. Documents of comtemporary Art. Cambridge: The MIT Press, 2009.

FOSTER, H. Design e crime. ARS, São Paulo, v. 9, n. 18, 2011. Electronic Document Format. Disponível em http:// www.revistas.usp.br/ars/article/view/52784/56627 Acesso em 19 Jan. 2016.

FLOOD, C. e GRINDON, G. Disobedient objects. Londres

V\&A Publishing, 2014.

FLUSSER, V. O mundo codificado. São Paulo: Cosac Naify, 2007.

GUATTARI, F. Caosmose: um novo paradigma estético. São Paulo: Ed. 34, 1992.

GEORGESCU-ROEGEN, N. O decrescimento - entropia, ecologia e economia. São Paulo: Senac, 2012.

GIL,V.A revolução dos tipos. Tese de Doutoradoapresentado à FAU, Universidade de São Paulo, São Paulo, 1999.

GOMBRICH, E. H. Os usos das imagens: estudos sobre a função social da arte e da comunicação visual. Porto Alegre: Bookman, 2012.
HARVEY, D. Condição pós-moderna. São Paulo: Loyola, 1992. HEATHERWICK, T. Making. Londres: Thames \& Hudson, 2012.

ROSA, H. Alienation et acceleration. Vers une théorie critique de la modernité tardive. e-book Canadá: La découverte, 2017.

LARRATT E MORRIS, Yayoi Kusama, Obsessão infinita. São Paulo: Centro Cultural Banco do Brasil, 2014 MALDONADO, T. Design Industrial. Lisboa: Edições 70. Cultura, sociedade e técnica. São Paulo:

Blucher, 2012.

MOLISSON, J. Where Children Sleep. London: Boot, 2010 MORIN, E. Introdução ao pensamento complexo. Porto Alegre: Sulina, 2011.

MUNARI, B. Design as art. Londres: Penguin, 2008

Drawing a tree. Verona: Edizioni Corraini, 2012

KOONS, J. Skin Fruit, New Museum, NY, 2010.

PAPANEK, V. Design for the real world, humam ecology and social change. Chicago: Chicago Review Press, 2005. PALLASMAA, J. Os olhos da pele: a arquitetura dos sentidos. Porto Alegre: Bookman, 2011.

PRIGOGINE, I. Do ser ao devir: nomes de deuses, entrevistas a Edmond Blattchen. São Paulo: UNESP. Belém: UEPA, 2002.

O fim das certezas. São Paulo: UNESP, 1996. Revista Flaunt, n. 154, Los Angeles, EUA, Flaunt, 2017. Revista I-D, n. 284, Londres, Levelprint, 2008.

Revista Vision 3.0, n. 02, Milão, European Network, 2017. WILCOX, C. Alexander McQueen. Londres: V\&A Publishing, 2016. 
Cólofon Edição, diagramação e produção Alécio Rossi Filho

Tipografia

DTL Prokyon - Designer Erhard Kaiser

Georgia-Designer Matthew Carter

\section{Capa e folhas de guarda}

Anúncios sobrepostos Metrô de Paris

Fotos de Alécio Rossi Filho

Papel - Alta alvura $120 \mathrm{~g}$

Impressão e acabamento - Pro-art Encadernações

(c) Alécio Rossi Filho

Fevereiro 2018 


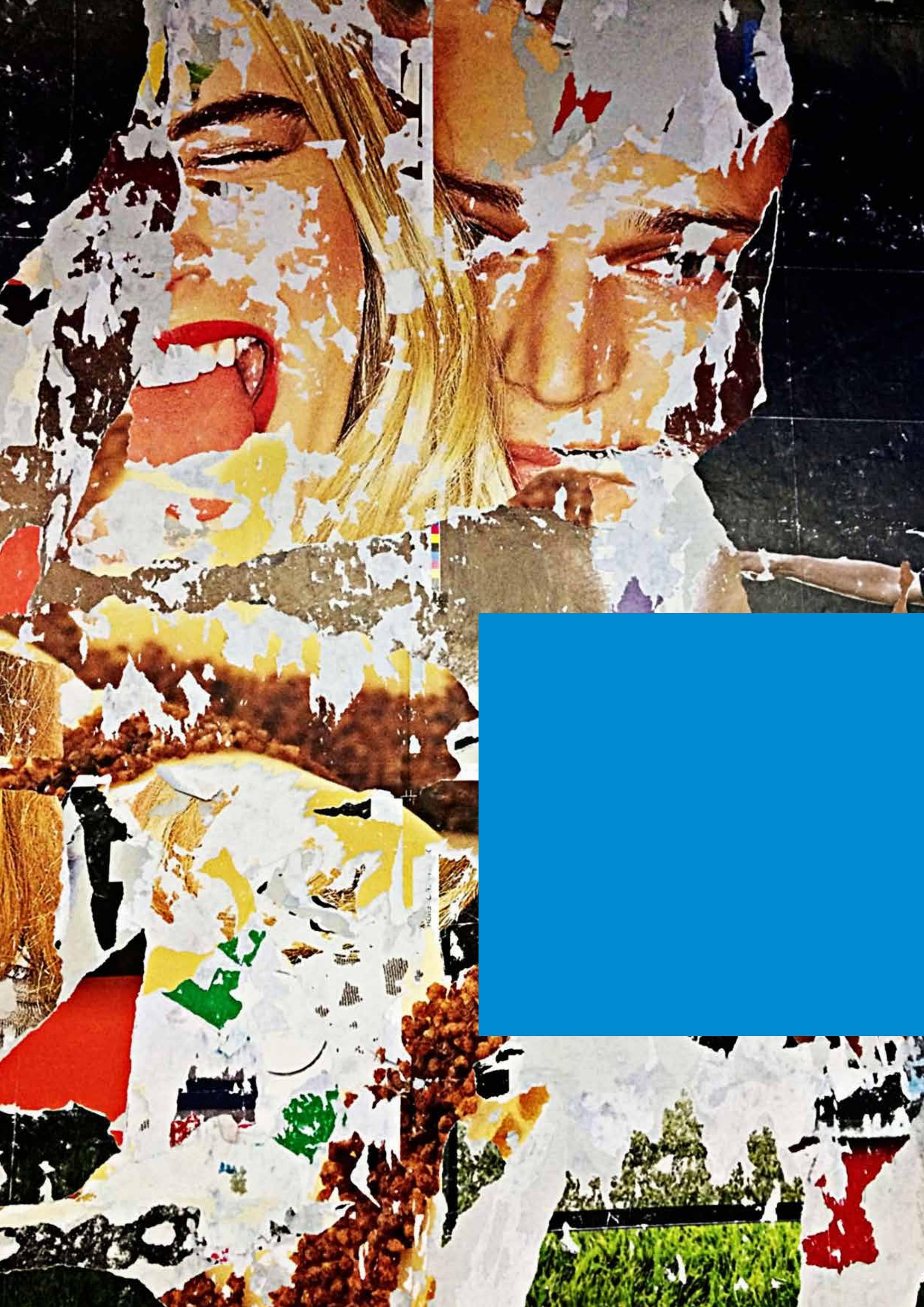

